\title{
Expression and Functional Analysis of the Fas-Associated Factor1 (Faf1) Gene
}

\author{
Dissertation
}

zur Erlangung des Doktorgrades

der Mathematisch-Naturwissenschaftlichen Fakultäten der Georg-August-Universität zu Göttingen

vorgelegt von

Khulan Janchiv

aus Ulaanbaatar, Mongolei

Göttingen 2006 
Referent:

Prof. Dr. W. Engel

Korreferentin:

PD Dr. S. Hoyer-Fender

Tag der mündlichen Prüfungen: 02.05.2006 


\section{INDEX}

INDEX

ABBREVIATIONS $\quad 5$

1. INTRODUCTION 9

1.1 Gene trapping in the mouse genome 9

1.2 Fas-associated factor 1 (Faf1) 13

$\begin{array}{ll}1.3 \mathrm{Fafl} \text { gene is trapped in the mouse line } 98-2 \mathrm{C} & 14\end{array}$

2. MATERIALS AND METHODS

$\begin{array}{ll}2.1 \text { Materials } & 15\end{array}$

2.1.1 Chemicals 15

2.1.2 Solutions, buffers and media 18

2.1.2.1 Agarose gel electrophoresis 18

2.1.2.2 SDS-PAGE 18

2.1.2.3 Frequently used buffers and solutions $\quad 19$

2.1.3 Laboratory materials 22

2.1.4 Sterilization of solutions and equipments 23

2.1.4 Sterilization of solutions and equipments 23

2.1.5.1 Media for bacteria 23

2.1.5.2 Media for cell culture $\quad 24$

2.1.6 Antibiotics 25

2.1.7 IPTG / X-Gal plate $\quad 25$

2.1.8 Bacterial Strains 25

2.1.9 Eukaryotic strains 26

2.1.10 Plasmids 26

2.1.11 Synthetic oligonucleotides 26

2.1.12 Mouse strains 28

2.1.13 Antibodies 28

2.1.14 Enzymes 28

2.1 .15 Kits 29

2.1.16 Instruments 29

2.2 Methods 30

2.2.1 Isolation of nucleic acids 30

2.2.1.1 Isolation of plasmid DNA 30 
2.2.1.1.1 Small-scale isolation of plasmid DNA 30

2.2.1.1.2 Large-scale preparation of plasmid DNA 31

2.2.1.1.3 Endotoxin free preparation of plasmid DNA 32

2.2.1.2 Isolation of genomic DNA 32

2.2.1.2.1 Isolation of genomic DNA from tissue samples 32

2.2.1.2.2 Isolation of genomic DNA from cultured cells 33

2.2.1.3.1 Isolation of total RNA from tissue samples and cultured cells 33

2.2.2 Determination of nucleic acid concentration 33

2.2.3 Gel electrophoresis $\quad 34$

2.2.3.1 Agarose gel electrophoresis of DNA 34

2.2.3.2 Agarose gel electrophoresis of RNA 34

2.2.3.3 SDS-PAGE for the separation of proteins 35

2.2.4 Isolation of DNA fragments after agarose gel electrophoresis 36

2.2.4.1 QIAquick gel extraction method 36

2.2.5 Enzymatic modifications of DNA 36

2.2.5.1 Restriction of DNA 36

2.2.5.2 Ligation of DNA fragments 36

2.2.5.3 TA-Cloning 37

2.2.6 Preparation of competent E.coli bacteria 37

2.2.7 Transformation of competent bacteria 38

2.2.8 Polymerase Chain Reaction (PCR) 38

2.2.8.1 PCR amplification of DNA fragments $\quad 39$

2.2.8.2 Reverse transcription PCR (RT-PCR) 39

2.2.8.3 One-Step RT-PCR 40

2.2.9 Protein methods $\quad 41$

2.2.9.1 Isolation of total proteins 41

2.2.9.2 Determination of protein concentration 41

2.2.10 Blotting techniques $\quad 42$

2.2.10.1 Southern blotting of DNA to nitrocellulose filters 42

2.2.10.2 Northern blotting of RNA onto nitrocellulose filter 42

2.2.10.3 Western blotting of protein onto PVDF membrane 43

2.2.11 "Random Prime" method for generation of ${ }^{32} \mathrm{P}$ labeled DNA 44 
2.2.12 Non-radioactive dye terminator cycle sequencing 44

2.2.13 Hybridization of nucleic acids $\quad 45$

2.2.14 Histological techniques 45

2.2.14.1.1 Tissue preparation for paraffin-embedding 45

2.2.14.1.2 Sections of the paraffin block 46

2.2.14.1.3 Preparation of paraffin sections 46

2.2.14.1.4 X-gal staining $\quad 47$

2.2.14.2.3 Immunofluorescence staining of mouse testes and tissues $\quad 48$

2.2.14.2.4 Immunofluorescence staining of cells 48

2.2.14.2.5 Immunocytochemical staining of germ cell suspensions. $\quad 49$

2.2.14.3 TUNEL-assay for detection of apoptotic cells. 49

2.2.15. Culture and immunostaining of preimplantation embryos 50

$\begin{array}{ll}2.2 .15 .1 \text { Superovulation } & 50\end{array}$

2.12.15.2 Recovery of preimplantation embryos $\quad 50$

2.2.15.3 In vitro culture of blastocyst stage embryos 51

2.2.15.4 Immunofluorescence staining of mouse preimplantation embryos 51

2.2.16.1Expression of recombinant proteins in the pET system 51

2.2.16.2 GST Pull-down assay 52

2.2.17 Immunoprecipitation $\quad 52$

2.2.18 Transfection of Hela Cells 53

2.2.19 Computer analysis 53

3. RESULTS

3.1 Expression of mouse Faf1 gene $\quad 55$

3.1.1 Expression of the Fafl gene in different tissues of the adult mouse 55

3.1.2 Expression of Fafl protein in mouse tissues $\quad 56$

3.1.3 Expression of Fafl gene during testicular development and in testes of different mutant mice 57

3.1.4 Expression of Fafl protein during testicular development and in the testis of different mutant mice 58

3.1.5 Expression of Fafl in male germ cells $\quad 61$

3.1.5.1 Fafl expression during male germ cell differentiation 61

3.1.5.2 Intracellular distribution pattern of Fafl 63

3.1.6. Expression of Fafl in ovary 64 
3.1.7.1 Expression of the Faf1 protein in oocytes and early cleavage embryos 65

3.1.7.2 Expression of the Faf1 in embryonic stem cells 66

$\begin{array}{ll}\text { 3.2 Functional analysis of Faf1 gene } & 67\end{array}$

3.2.1 Establishment of methods for genotyping the gene trap 98-2C line 67

3.2.2 Identification of the integration site of gene trap vector in

Fafl gene $\quad 68$

3.2.3 Developmental consequences of trapped Fafl gene 72

3.2.4 Expression of embryonic Fafl gene during preimplantation $\quad 77$

3.2.5 Reproductive functions of Fafl in male animals 78

3.2.5.1 Fertility test experiments $\quad 78$

3.2.5.2 Expression analysis of the Fafl trapped allele $\quad 80$

3.2.6 Fafl protein analysis

Identification of the interaction partner of Fafl 85

$\begin{array}{ll}\text { 4. DISCUSSION } & 88\end{array}$

4.1 Expression analysis of the Fafl gene $\quad 88$

4.2 Functional analysis of Faf1 gene $\quad 89$

4.3 Fafl is involved in the ubiquitin-proteasome pathway 91

4.4 Ubiquitin in preimplantation embryonic development 93

4.5 Ubiquitin-proteasome degradation pathway and gametogenesis 94

4.6 Mutant cause preimplantation embryonic death in other genes 96

5. SUMMARY 99

$\begin{array}{ll}\text { 6. REFERENCES } & 101\end{array}$

$\begin{array}{ll}\text { ACKNOWLEDGEMENTS } & 111\end{array}$

$\begin{array}{lr}\text { CURRICULUM VITAE } & 112\end{array}$ 


\section{ABBREVIATIONS}

\begin{tabular}{|c|c|}
\hline $\mathrm{ABI}$ & applied Biosystem Instrument \\
\hline APS & ammonium peroxodisulfate \\
\hline ATP & adenosintriphosphate \\
\hline $\mathrm{BCP}$ & 1-bromo-3-chloropropane \\
\hline$\beta$-gal & $\beta$-galactosidase \\
\hline $\mathrm{bp}$ & base pair \\
\hline BSA & bovine serum albumin \\
\hline${ }^{\circ} \mathrm{C}$ & degree Celsius \\
\hline cDNA & complementary DNA \\
\hline Cy3 & indocarbocyanine \\
\hline dATP & desoxyriboadenosintriphosphate \\
\hline $\mathrm{dH}_{2} \mathrm{O}$ & distil Water \\
\hline DAPI & diamidino-2-phenylindole dihydrochloride \\
\hline $\mathrm{dCTP}$ & desoxyribocytosintriphosphate \\
\hline DMSO & dimethyl sulfoxide \\
\hline DEPC & diethylpyrocarbonate \\
\hline DNA & deoxyribonucleic acid \\
\hline DNase & deoxyribonuclease \\
\hline dNTP & deoxynucleotidetriphosphate \\
\hline dpc & day post coitus \\
\hline DTT & dithiothreitol \\
\hline EDTA & ethylene diamine tetraacetic acid \\
\hline ES & embryonic stem \\
\hline Fafl & Fas-associated factor-1 \\
\hline FCS & fetal calf serum \\
\hline FITC & fluorescein isothiocyanate \\
\hline $\mathrm{g}$ & gravity \\
\hline gm & gram \\
\hline GST & glutathione S-transferase \\
\hline HEPES & N-(-hydroxymethyl) piperazin, N'-3-propansulfoneacid \\
\hline
\end{tabular}




\begin{tabular}{|c|c|}
\hline HPLC & high performance liquid chromatograpy \\
\hline $\operatorname{hr}(s)$ & hour(s) \\
\hline IPTG & isopropyl- $\beta$-thiogalactopyranoside \\
\hline IRES & internal ribosome entry site \\
\hline IVF & in vitro fertilisation \\
\hline $\mathrm{JL}$ & Jackson Laboratory \\
\hline $\mathrm{kb}$ & kilobase pairs \\
\hline LB & luria-Bertrani \\
\hline LIF & recombinant leukaemia inhibitory factor \\
\hline LPS & lipopolysaccharides \\
\hline M & molarity \\
\hline $\mathrm{MEF}$ & mouse embryonic fibroblast \\
\hline MOPS & 3-[N-Morpholino]-Propanesulfate \\
\hline mRNA & messenger Ribonucleic acid \\
\hline $\mathrm{mg}$ & milligram \\
\hline $\mathrm{ml}$ & millileter \\
\hline$\mu l$ & microliter \\
\hline$\mu \mathrm{m}$ & micrometer \\
\hline $\min$ & minute \\
\hline $\mathrm{NaAc}$ & sodium acetate \\
\hline NBT & nitro-blue tetrazolium \\
\hline NCBI & National Center for Biotechnology Information \\
\hline $\mathrm{NeO}$ & neomycin \\
\hline ng & nanogram \\
\hline NLS & nuclear localization sequence \\
\hline $\mathrm{nm}$ & nanometer \\
\hline NTP & nucleotidetriphospate \\
\hline UBA & ubiquitin binding domain \\
\hline UBX & ubiquitin like domain \\
\hline OD & optimal density \\
\hline ORF & open reading frame \\
\hline PAGE & polyacrylamide gel electrophoresis \\
\hline PCR & polymerase chain reaction \\
\hline $\mathrm{pH}$ & preponderance of hydrogen ions \\
\hline
\end{tabular}




\begin{tabular}{ll}
\hline pmol & picomol \\
PBS & phosphatebuffersaline \\
PBT & phosphatebuffersaline + Tween 20 \\
PMSF & phenylmethylsulfonyl fluoride \\
RNA & ribonucleic acid \\
Rnase & ribonuclease \\
RNasin & ribonuclease inhibitor \\
rpm & revolution per minute \\
RT & room temperature \\
RT-PCR & reverse transcriptase-PCR \\
SDS & sodium dodecylsulfate \\
SDS-PAGE & SDS-Polyacrylamide gel electrophoresis \\
sec & second \\
Taq & thermus aquaticus \\
TBE & tris-borate-EDTA-electrophoresis buffer \\
TE & tris-EDTA buffer \\
TEMED & tetramethylethylene diamine \\
Tris & trihydroxymethylaminomethane \\
U & unit \\
UV & ultra violet \\
V & voltage \\
w/v & weight/volume \\
X-Gal & -bromo-4-chloro-3-indolyl \\
&
\end{tabular}

\section{Symbol of amino acids}

$\begin{array}{lll}\text { A } & \text { Ala } & \text { Alanine } \\ \text { B } & \text { Asx } & \text { Asparagine or Asparatic acid } \\ \text { C } & \text { Cys } & \text { Cystine } \\ \text { D } & \text { Asp } & \text { Asparatic acid } \\ \text { E } & \text { Glu } & \text { Glutamic acid } \\ \text { F } & \text { Phe } & \text { Phenylalanine } \\ \text { G } & \text { Gly } & \text { Glycine } \\ \text { H } & \text { His } & \text { Histidine } \\ \text { I } & \text { Ile } & \text { Isoleucine } \\ \text { K } & \text { Lys } & \text { Lysine }\end{array}$


Abbreviations

\begin{tabular}{lll}
\hline L & Leu & Leucine \\
M & Met & Methionine \\
N & Asn & Asparagine \\
P & Pro & Proline \\
Q & Gln & Glutamine \\
R & Arg & Arginine \\
S & Ser & Serine \\
T & Thr & Threonine \\
V & Val & Valine \\
W & Trp & Tryptophan \\
Y & Tyr & Tyrosine \\
Z & Glx & Glutamine or Glutamic acid
\end{tabular}

\section{Symbols of nucleic acid}
A
Adenosine
C
Cytidine
G
Guanosine
$\mathrm{T}$
Thymidin 


\section{INTRODUCTION}

\subsection{Gene trapping in the mouse genome}

Manipulation of the genome for in vivo identification of gene functions requires reliable and predictable strategies to disrupt a given locus. Gene trap strategies have proven to be powerful tools not only to study the expression of genes in vivo, but also to identify their functions, because gene trap constructs commonly cause disruption of the targeted gene (Skarnes et al., 1992; Zambrowicz et al., 1998; Stanford et al., 2001). Gene trapping (GT) is a method of random insertional mutagenesis that uses a gene trap vector containing a DNA coding for a reporter or marker gene as a mutagen. Generally, a gene trap vector contains the intron and splice acceptor (SA) sequence from the mouse gene engrailed-2 (En-2), joined upstream of promoterless reporter $\beta$ - galactosidase gene (lacZ) and neomycin phosphotransferase gene (neo) as selector, and is then followed by the SV40 polyadenylation signal at the 3' end. In some GT vectors, the internal ribosomal entry site (IRES) from the encephalomyocarditis virus is located in front of the reporter gene to allow the cap-independent translation of the lac $Z$ from fusion transcript. Integration of the gene trap vector into the intron of a gene in the correct orientation was predicted to create lac $Z$ fusion transcript, and if the reading frames of the endogenous genes and lac $Z$ are the same, an active $\beta$-galactosidase fusion protein should be produced. A gene trap vector was designed to generate a spliced fusion transcript between the reporter gene and the endogenous gene present at the site of integration (Fig. 1.1) (Brenner et al., 1989; Gossler et al., 1989; Kerr et al., 1989).

To generate a large scale of gene trapped cells, embryonic stem cells (ES) are electroporated with linearized GT vector. After culture of transfected cells in G418 selection medium, lacZ expressing clones are detected by staining the cells for Bgalactosidase activity. The lac $Z$ reporter gene can only be expressed if it is inserted in an intron of a transcriptionally active gene. Using $5^{\prime}$ rapid amplification of cDNA end (5'RACE), the 5' trapped exon can be easily determined from the spliced fusion transcript without having to clone the insertion site from the genomic DNA. Alignment of 5'RACE sequence in genomic, cDNA and EST databases will allow identifying a trapped gene. 
$\mathbf{A}$

\begin{tabular}{|c|c|c|c|c|c|c|c|}
\hline $\begin{array}{c}\text { pBluescrit } \\
\text { KS }\end{array}$ & En 2-SA & IRIS & LacZ & $\begin{array}{c}\text { SV40 } \\
\text { pA }\end{array}$ & $\begin{array}{l}\text { B actin } \\
\text { promotor }\end{array}$ & Neo & Pax2 \\
\hline
\end{tabular}

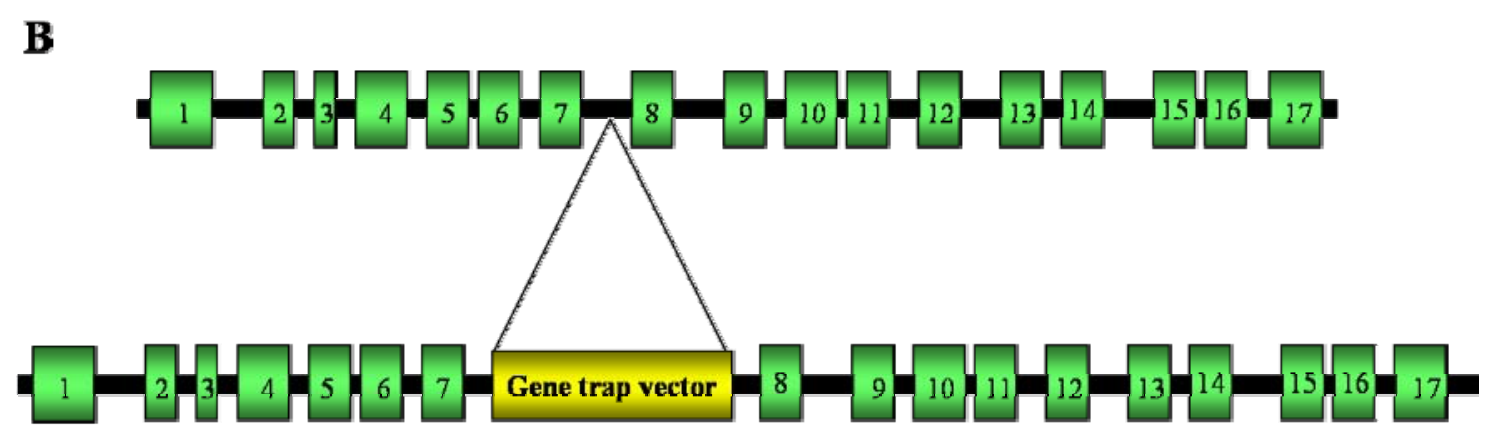

Figure 1.1 (A) Schematic representation of the gene trap vector used in this study. The gene trap vector contains the intron and splice acceptor (SA) sequence from the mouse gene engrailed-2 (En-2) joined upstream of promoterless reporter $\beta$-galactosidase gene (lacZ) and followed by the SV40 polyadenylation signal (pA) at the 3' end and the internal ribosomal entry site (IRES) from the encephalomyocarditis virus. ATG (translation initiation codon) is located in front of the reporter gene to allow the cap-independent translation of the lac $Z$ from fusion transcript. The vector contains also the human $\beta$-actin promoter and neomycin phosphotransferase (neo) gene as selector. In this vector transcription of neo is under the control of a constitutive promoter and the LacZ expression depends on the activity of the trapped gene. (B)The gene trap cassette is inserted in intron 7 of the Fafl gene. 
To determine the function of a trapped gene, chimeric mice are produced by injection of gene trapped ES cells into blastocyts. The recombinant ES cells and the endogenous ES cells of blastocyts participate in the development of chimeric mice. If the gene trapped EScells are involved in development of germ cells of chimeras, then the trapped allele will be transmitted to their offspring. Breeding of heterozygous offspring will result in mice homozygous for the trapped gene in the F2 generation. Because LacZ expression in gene trapped mice is under control of the promoter of the trapped gene, monitoring the lac $Z$ activity in heterozygous embryos should enable one to readily visualize the expression pattern of endogenous gene during development. Using the gene trap strategy (Fig.1.2), several groups were able to isolate and study new developmental regulatory genes and to produce the corresponding mutant mice. 


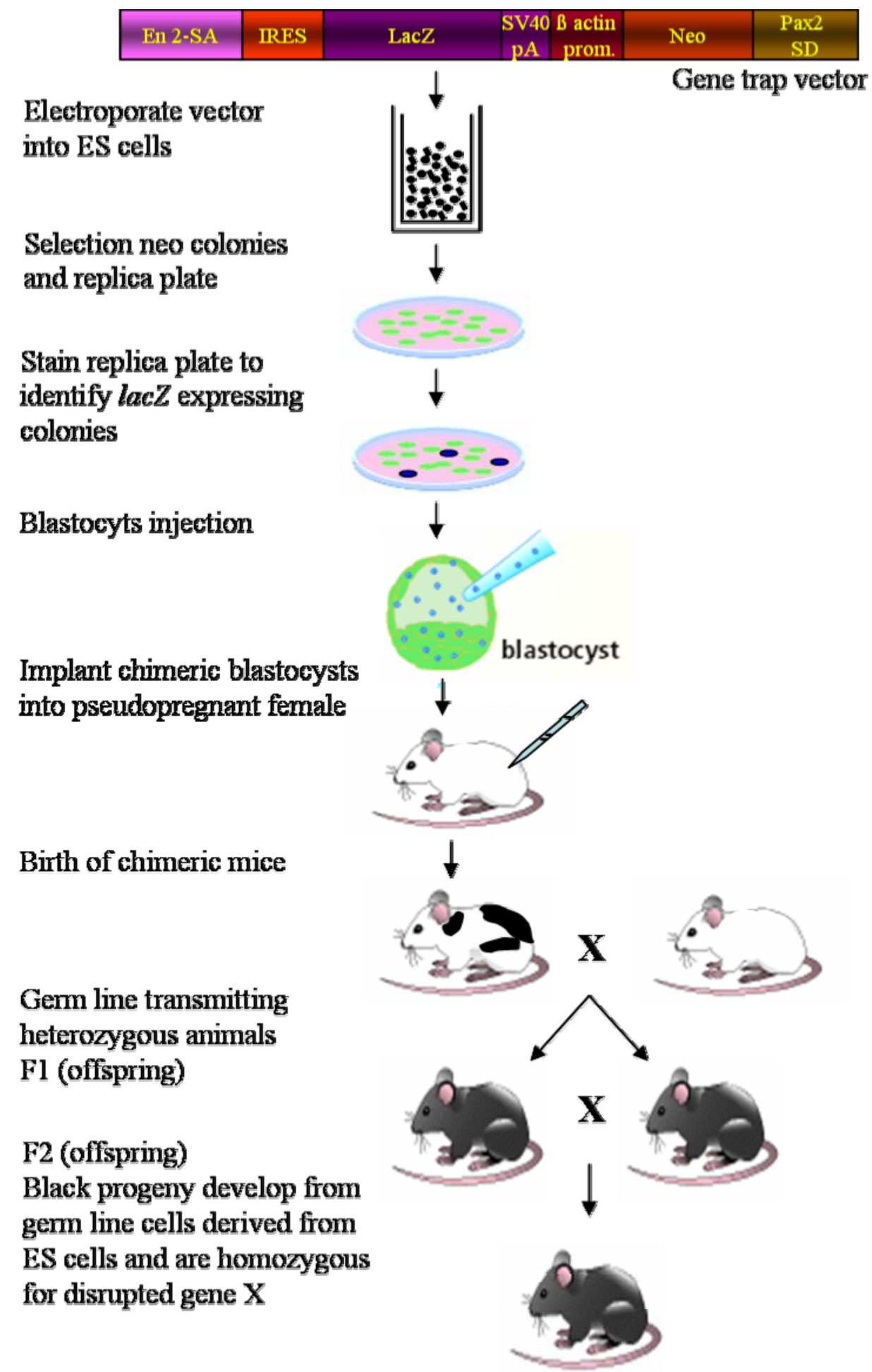

Figure 1.2 Generation of a gene trap mouse line. 


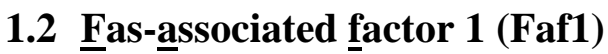

Faf1 was first identified by yeast two hybrid assay using the cytoplasmic domain of FAS as bait (Chu et al., 1995). Fas, a member of the tumor necrosis factor receptor family (TNF-R), induces apoptosis when crosslinked with Fas ligand (Nagata, 1997). Fas mediated apoptosis has been implicated in the down regulation of the immune response, the depletion of peripheral autoreactive $\mathrm{T}$ lymphocytes and maintenance of sites of immune privilege (Abbas, 1996; Nagata, 1997). In testis, FasL is expressed in Sertoli cells (Suda et al., 1994; French et al., 1996) and has proven to be a major determinant in maintaining the immune privilege of testis (Bellgrau et al., 1995; Sanberg et al., 1996). Functional role for Sertoli cell-expressed FasL in inducing apoptosis of Fas-expressing germ cells has been recently demonstrated (Lee et al., 1997; 1999).

The specific binding of Faf1 to the cytoplasmic domain of Fas led to suggest that the Faf1 is a component of the death-inducing signaling complex in Fas-mediated apoptosis. Recently, several groups reported that overexpression of human Fafl can initiate apoptosis in transfected cell lines (Chu et al., 1995; Ryu et al., 2003).

Fafl has been cloned in human (Walzak and Krammer 2000), in mouse (Chu et al., 1995) and in quail (Fröhlich et al., 1998). Human Fafl gene was localized to chromosome 1p32 (Ryu et al., 2000) and the mouse gene to chromosome 4C6 (Kikyo et al., 1996). A sequence similarity search revealed that the quail Fafl shares an amino acid sequence similarity of $88 \%$ with mouse Fafl and has $84 \%$ identical amino acids (Fröhlich et al., 1998). Mouse Fafl amino acid sequence has $96 \%$ homology with that of human FAF1 (Ryu and Kim 2001).

Although Faf1 apoptotic potential has been demonstrated, sequence homology search in protein databases does not show typical death motifs such as the death domain and death effector domain (DED) in primary structure of Faf1. Instead, Fafl has sequence motifs that are present in the proteins of the ubiquitination pathway. The Fafl contains a UBX (ubiquitin-like) domain at the N-terminal end and the UBA (ubiquitin-associated) domain at the C-terminal end (Buchberger, 2002). The presence of both domains in Fafl suggests that the Faf1 is involved in the ubiquitination pathway. Northern blot analysis revealed that the Fafl is expressed as a $2.8-\mathrm{kb}$ mRNA in various human tissues. High expression of Faf1 was seen in testis, brain and thymus. Western blot analysis of various human cell lines with a polyclonal antibody against Faf1 revealed protein products of two sizes, 74-kDa and 40- 
$\mathrm{kDa}$ (Ryu et al., 1999). The 74-kDa protein corresponds well with the expected protein size of the predicted amino acid sequence of human FAF1. Expression analysis of Faf1 during embryonic development of quail revealed that Fafl is bearly detected in pluripotent embryonic cells (Eo). After induction of differention by basic FGF, Fafl mRNA was detected as early as two hours after induction. The inducibility of quail Fafl was restricted to the pluripotent embryonic cells. Whole mount in situ hybridization of E1 embryos (at the definitive primitive streak stage) revealed an intense and ubiquitous staining throughout the three embryonic germ layers (Fröhlich et al., 1998).

\subsection{Faf1 gene is trapped in the mouse line 98-2C}

In a large gene trap screen, the group of Prof. Dr. Peter Gruss in Max-Plank-Institute for biophysical Chemistry, Göttingen, has analysed the $L a c Z$ expression pattern in several mouse lines. Analysis of $L a c Z$ expression in the mouse $98-2 \mathrm{C}$ line revealed that the $L a c Z$ is highly expressed in brain and testis. 5' RACE method was not able to amplify the trapped sequence. Therefore, a genomic phage library of a heterozygous mouse was generated in the DASH-II vector .Two independent recombinant phage clones carrying inserts of 21and 17.2-kb were isolated with $L a c Z$ and neo-specific hybridization probes. Regions flanking the integrated vector were sequenced and searched using Blast against mouse genome databases. Sequence alignment revealed that the gene trap vector is integrated in the intron 7 of the Fafl gene. To genotype animals of the 98-2C mouse line, a LacZ specific probe we used. Analyses of homozygous mutant mice, which have been genotyped with the quantative Southern blot, revealed that male and female mutant mice appear normal but mutant males are infertile.

Aims of this work

1. Analysis of Fafl expression during embryonic and germ cell development

2. Establishment of a direct method for genotyping the 98-2C gene trap line

3. Identification of the function of the Fafl gene 


\section{MATERIALS AND METHODS}

\subsection{Materials}

\subsubsection{Chemicals}

Acrylamide

Acetic acid

Agar

Agarose

Ammonium acetate

Ammonium persulfate

Ampicillin

Ampuwa

Bacto-tryptone

Bacto-Yeast-Extract

BCIP

Bisacrylamide

Blocking powder

BSA

Coomasie G-250

Choloroform

DAPI

Dextran sulfate

Diethyl pyrocarbonate (DEPC)

Dimethyl sulfoxid (DMSO)

Dithiothreitol

DNA Markers

dNTPs (100 mM)

Dye Terminator Mix

Ethanol

Ethidium bromide

Ficoll 400
Serva, Heidelberg

Merck, Darmstadt

Difco, Detroit, USA

Invitrogen, Karlsruhe

Fluka, Neu Ulm

Sigma, Deisenhofen

Sigma, Deisenhofen

Fresenius, Bad Homburg

Difco, Detroit, USA

Difco, Detroit, USA

Boehringer, Mannheim

Serva, Heidelberg

Boehringer, Mannheim

Biomol, Hamburg

Sigma, Deisenhofen

Baker, Deventer, NL

Vector, Burfingame

Amersham pharmalia, Freiburg

Sigma, Deisenhofen

Merck, Darmstadt

Sigma, Deisenhofen

Invitrogen, Karlsruhe

Invitrogen, Karlsruhe

Applied Biosystems

Baker, Deventer, NL

Sigma, Deisenhofen

Amersham Pharmalia, Freiburg 
FCS

Formaldehyde

Formamide

Glutaraldehyde

Glycerol

Glycine

Goat serum

$\mathrm{HCl}$

$\mathrm{H}_{2} \mathrm{O}_{2}$

HEPES

IPTG

Isopropanol

$\mathrm{KCl}$

Lambda DNA

Methanol

$\mathrm{MgCl}_{2}$

MOPS

Methyl benzoat

$\beta$-Mercaptoethanol

Mineral oil

$\mathrm{NaCl}$

$\mathrm{Na}_{2} \mathrm{HPO}_{4}$

$\mathrm{NaH}_{2} \mathrm{PO}_{4}$

$\mathrm{NaHCO}_{3}$

$\mathrm{NaN}_{3}$

$\mathrm{NaOH}$

NBT

Orange $\mathrm{G}$

PBS

Phosphoric acid

Picric acid

Phenol

Proteinase K
Invitrogen, Karlsruhe

Invitrogen, Karlsruhe

Fluka, Neu Ulm

Sigma, Deisenhofen

Invitrogen, Karlsruhe

Biomol, Hamburg

Sigma, Deisenhofen

Merck, Darmstadt

Merck, Darmstadt

Merck, Darmstadt

Biomol, Hamburg

Merck, Darmstadt

Merck, Darmstadt

Roche, Penzberg

Merck, Darmstadt

Merck, Darmstadt

Merck, Darmstadt

Fulka, Neu Ulm

Serva, Heidelberg

Sigma, Deisenhofen

Merck, Darmstadt

Merck, Darmstadt

Merck, Darmstadt

Merck, Darmstadt

Merck, Darmstadt

Merck, Darmstadt

Roche, Penzberg

Sigma, Deisenhofen

Invitrogen, Karlsruhe

Merck, Darmstadt

Fulka, Neu Ulm

Invitrogen, Karlsruhe

Roche, Penzberg 
Protein marker

$\left[\alpha^{32} \mathrm{P}\right]-\mathrm{dCTP}$

Rediprime $^{\mathrm{TM}}$ II

RNase Inhibitor

RNA length standard

RNase away

Salmon sperm DNA

SDS

Select Peptone

Sodium acetate

Sodium citrate

TEMED

Triton X-100

Tris

Tween-20

X-Gal

Xylencyanol

Cell culture media
Biorad, Sigma

Amersham Pharmalia, Braunschweig

Amersham Pharmalia, Freiburg

Roche, Penzberg

Invitrogen, Karlsruhe

Biomol, Hamburg

Sigma, Deisenhofen

Serva, Heidelberg

Gibco/BRL, Eggenstein

Merck, Darmstadt

Merck, Darmstadt

Serva, Heidelberg

Serva, Heidelberg

Sigma, Deisenhofen

Sigma, Deisenhofen

Biomol, Hamburg

Bio-Rad, München

Invitrogen, Karlsruhe

All those chemicals which are not mentioned above were bought from Merck, Darmstadt, or Roth, Karlsruhe. 


\subsubsection{Solutions, buffers and media}

\subsubsection{Agarose gel electrophoresis}

5x TBE buffer

Glycerol loading buffer -I

Glycerol loading buffer -II

\subsubsection{SDS-PAGE}

40\% Acrylamide stock solution

Sample buffer $(2 \mathrm{x})$
$450 \mathrm{mM}$ Trisbase

$450 \mathrm{mM}$ Boric acid

20 mM EDTA (pH 8)

$10 \mathrm{mM}$ Tris/HCl (pH 7.5)

10 mM EDTA (pH 8)

0.025\% Bromophenol blue

$0.025 \%$ Xylenecyanol

$30 \%$ Glycerol

10 mM Tris/HCl (pH 7.5)

10 mM EDTA (pH 8)

$0.025 \%$ Orange $\mathrm{G}$

$30 \%$ Glycerol

Acrylamide $29.2 \%(\mathrm{w} / \mathrm{w})$

Bis-acrylamide $0.8 \%(\mathrm{w} / \mathrm{w})$

10\% Ammonium persulfate

solution in $\mathrm{H}_{2} \mathrm{O}$

0.5 M Tris/HCl (pH 6.8)

$20 \%$ Glycerol

$4 \%$ SDS

$10 \% \beta$-Mercaptoethanol 
Running buffer (5x)

Stacking gel buffer $(4 \mathrm{x})$

Separating gel buffer $(4 \mathrm{x})$
25 mM Tris/ $\mathrm{HCl}(\mathrm{pH} 8.3)$

192 mM Glycine

$0.1 \%$ SDS

0.5 M Tris/HCl (pH 6.8)

$0.4 \%$ SDS

1.5 M Tris/HCl (pH 8.3)

$0.4 \%$ SDS

\subsubsection{Frequently used buffers and solutions}

Denaturation solution

$1.5 \mathrm{M} \mathrm{NaCl}$

$0.5 \mathrm{M} \mathrm{NaOH}$

Denhardt's solution (50x)

$1 \% \mathrm{BSA}$

1\% Polyvinylpyrrolidon

1\% Ficoll 400

Denaturization solution

$0.25 \mathrm{~N} \mathrm{HCl}$

E-buffer (10x)

$300 \mathrm{mM} \mathrm{NaH} 2 \mathrm{PO}_{4}$

$50 \mathrm{mM}$ EDTA

Elution buffer

$1.5 \mathrm{M} \mathrm{NaCl}$

$20 \mathrm{mM}$ Tris/ $\mathrm{HCl}$ (pH 7.5)

$1 \mathrm{mM}$ EDTA

Bouin's solution

15 volume of picric acid (in $\left.\mathrm{H}_{2} \mathrm{O}\right)$

5 volumes Formaldehyde

1 volume Acetic acid 
Hybridisation solution I

Hybridisation solution II

Ligation buffer (10x)

Lysis buffer I

Lysis-buffer II

Lysis-buffer III(embryo)

Lysis-buffer IV 5x SSPE solution

5x Denhardt's solution

$0.1 \%$ SDS

$5 \mathrm{x} \mathrm{SSC}$

$5 \mathrm{x}$ Denhardt's solution

$10 \%$ Dextran sulfate

$0.1 \%$ SDS

$600 \mathrm{mM}$ Tris/HCl (pH 7.5)

$80 \mathrm{mM} \mathrm{MgCl}_{2}$

$100 \mathrm{mM}$ DTT

$100 \mathrm{mM}$ Tris/HCl (pH 8.0)

$100 \mathrm{mM} \mathrm{NaCl}$

100 mM EDTA

$0.5 \%$ SDS

$100 \mathrm{mM}$ Tris/HCl (pH 8.0)

5 mM EDTA

$200 \mathrm{mM} \mathrm{NaCl}$

$0.2 \% \mathrm{SDS}$

$100 \mu \mathrm{g} / \mathrm{ml}$ proteinase $\mathrm{K}$

$50 \mathrm{mM}$ Tris/ $\mathrm{HCl}(\mathrm{pH} 8.0)$

0.5 mM EDTA (pH 8.0)

$0.5 \%$ Tween 20

$0.2 \mathrm{mg} / \mathrm{ml}$ proteinase $\mathrm{K}$

1\% Tween20

1\% Tritonx-100

5mM EDTA

10mM Tris $\mathrm{pH} 7.5$

2mM DTT 
$20 \mu \mathrm{l} / \mathrm{ml}$ Proteinase K

Lysis buffer A

10mM Tris/HCl pH 8.0

$1 \mathrm{mM}$ EDTA

$2.5 \%$ SDS

$1 \mathrm{mM}$ PMFS

Lysis buffer B

50mM Tris-HCl, $\mathrm{pH} 7.5$

$150 \mathrm{mM} \mathrm{NaCl}$

$1 \%$ Nonidet P40

$0.5 \%$ sodium deoxycholate

1 Protease inhibitor cocktail tablet

10 X MOPS Buffer

$41.8 \mathrm{~g}$ MOPS

$16.6 \mathrm{ml} 3 \mathrm{M}$ Sodium acetate

$20 \mathrm{ml} 0.5 \mathrm{M}$ EDTA

in 1 liter of DEPC Water

adjust $\mathrm{pH}$ to 6.75

Neutralisation solution

$1.5 \mathrm{M} \mathrm{NaCl}$

$1 \mathrm{M}$ Tris $/ \mathrm{HCl}(\mathrm{pH} 7.0)$

PBS buffer

$130 \mathrm{mM} \mathrm{NaCl}$

$7 \mathrm{mM} \mathrm{Na}_{2} \mathrm{HPO}_{4}$

$4 \mathrm{mM} \mathrm{NaH}_{2} \mathrm{HPO}_{4}$

PBT buffer

$0.1 \%$ Tween-20 in PBS $(1 \mathrm{x})$

$\operatorname{SSC}(20 \mathrm{x})$

$3 \mathrm{M} \mathrm{NaCl}$

$0.3 \mathrm{M} \mathrm{Na}_{3}$ citrate (pH 7.0)

SSPE (20x)

0.02 M EDTA

$0.2 \mathrm{M} \mathrm{NaH}_{2} \mathrm{PO}_{4}$ 
3.6 $\mathrm{M} \mathrm{NaCl}(\mathrm{pH} 7.0)$

Stop-Mix I

95\% Formamide

$20 \mathrm{mM}$ EDTA

0.05\% Bromphenol blue

$0.05 \%$ Xylene cyanol

Stop-Mix II

15\% Ficoll 400

$200 \mathrm{mM}$ EDTA

$0.1 \%$ Orange $\mathrm{G}$

TE-buffer

10 mM Tris/HCl (pH 8.0)

1 mM EDTA

Washing solution I

2x SSC

$0.1 \%$ SDS

Washing solution II

$0.2 \mathrm{x}$ SSC

\subsubsection{Laboratory materials}

The laboratory materials, which are not listed here, were bought from Schütt and Krannich (Göttingen).

Whatman blotting paper

Cell culture flask

Culture slides

Disposable filter Minisart NMI

Filter paper 0858

Hybond C
Schleicher and Schüll, Dassel (GB 002, GB 003 and GB 004) Greiner, Nürtingen

Falcon

Sartorius, Göttingen

Schleicher and Schüll, Dassel

Amersham, Braunschweig 
Hybond N

Petri dishes

Pipette tips

Microcentrifuge tubes

Transfection flasks

$\mathrm{X}$-ray films

Superfrost Slides
Amersham, Braunschweig

Greiner, Nürtingen

Eppendorf, Hamburg

Eppendorf, Hamburg

Lab-Tek/Nalge, Nunc, IL, USA

Amersham, Braunschweig

Menzel, Gläser

\subsubsection{Sterilisation of solutions and equipments}

All solutions that are not heat sensitive were sterilised at $121^{\circ} \mathrm{C}, 10^{5} \mathrm{~Pa}$ for $60 \mathrm{~min}$ in an autoclave (Webeco, Bad Schwartau). Heat sensitive solutions were filtered through a disposable sterile filter ( 0.2 to $0.45 \mu \mathrm{m}$ pore size). Plastic wares were autoclaved as above. Glasswares were sterilised overnight in an oven at $220^{\circ} \mathrm{C}$.

\subsubsection{Media, antibiotics and agar-plates}

\subsubsection{Media for bacteria}

LB Medium ( $\mathrm{pH} 7.5)$ :

$1 \%$ Bacto-trypton

$0.5 \%$ Yeast extracts

$1 \% \mathrm{NaCl}$

LB-Agar:

$$
\begin{aligned}
& 1 \% \text { Bacto-trypton } \\
& 0.5 \% \text { Yeast extracts } \\
& 1 \% \mathrm{NaCl} \\
& 1.5 \% \mathrm{Agar}
\end{aligned}
$$

The LB medium was prepared with distilled water, autoclaved and stored at $4^{\circ} \mathrm{C}$. 


\subsubsection{Media for cell culture}

M2 and M16 media were purchased from Sigma, (Deisenhofen) and were used for washing and cultivation of mouse preimplantation embryos.

Embryonic stem (ES) cell medium:

$\begin{array}{ll}\text { DULBECCO's MEM (DMEM) } \\ 1 \mathrm{mM} & \text { Non essential amino acids } \\ 1 \mathrm{mM} & \text { Sodium pyruvate } \\ 10 \mu \mathrm{M} & \text { B-Mercaptoethanol } \\ 2 \mathrm{mM} & \text { L-Glutamine } \\ 20 \% & \text { Fetal calf serum (FCS) } \\ 1000 \mathrm{U} / \mathrm{ml} & \text { Recombinant leukaemia inhibitory factor (LIF) }\end{array}$

Fibroblast cell medium (MEFs):

$\begin{array}{ll}\text { DULBECCO's MEM (DMEM) } \\ 2 \mathrm{mM} & \text { L-Glutamine } \\ 10 \% & \text { FCS }\end{array}$

For long time storage of the cells in liquid nitrogen, the following freezing media were used:

Freezing medium: $\quad$ DULBECCO's MEM (DMEM)

$\begin{array}{ll}50 \% & \text { FCS } \\ 20 \% & \text { DMSO }\end{array}$


Embryo culture medium: M16 contains pyruvate and lactate as energy sources since preimplantation embryos do not utilize glucose efficiently. M2 Medium is a further modification of M16 that substitutes HEPES buffer in place of some of the bicarbonate. M2 is used for collecting and handling embryos for prolonged periods outside a CO2 incubator.

\subsubsection{Antibiotics}

Stock solutions were prepared for the antibiotics. The stock solutions were then filtered through sterile disposable filters and stored at $-20^{\circ} \mathrm{C}$. When antibiotics were needed, in each case, it was added after the autoclaved medium has cooled down to a temperature lower than $55^{\circ} \mathrm{C}$.

Master solution Solvent Final concentration

$\begin{array}{llll}\text { Ampicillin } & 50 \mathrm{mg} / \mathrm{ml} & \mathrm{H}_{2} \mathrm{O} & 50 \mu \mathrm{g} / \mathrm{ml} \\ \text { Kanamycin } & 25 \mathrm{mg} / \mathrm{ml} & \mathrm{H}_{2} \mathrm{O} & 50 \mu \mathrm{g} / \mathrm{ml}\end{array}$

\subsubsection{IPTG / X-Gal plate}

LB-agar with $50 \mu \mathrm{g} / \mathrm{ml}$ ampicillin, $100 \mu \mathrm{M}$ IPTG and $0.4 \%$ X-Gal was poured into petri dishes. The dishes were stored at $4^{\circ} \mathrm{C}$.

\subsubsection{Bacterial strains}
E. coli $\mathrm{DH} 5 \alpha$
(Invitrogen, Karlsruhe)
E. coli BL21
(Novangen, Darmstadt) 


\subsubsection{Eucaryotic strains}

F9 mouse teratocarcinoma cell line, Sherman et al., (1976), American Type Culture Collection (ATCC), Rockville, USA.

Tera1 human embryonic carcinoma cell line, Beatrice et al., (1997), American Type Culture Collection (ATCC), Rockville, USA.

Hela human cervical adenocarcinoma cell line, American Type Culture Collection (ATCC), Rockville, USA.

\subsubsection{Plasmids}

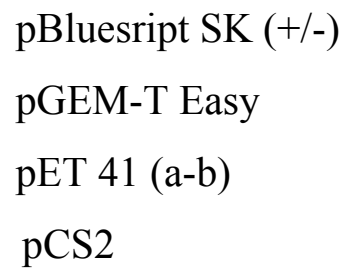

(Stratagene, La Jolla, USA)

(Promega, Wisconsin, USA)

(Novagen, Darmstadt)

(Dr.H.Hammerschmidt, Freiburg) to generate epitop tagged fusion protein, expressed in mammalian cells

\subsubsection{Synthetic oligonucleotides}

The synthetic oligonucleotide primers used in this study were obtained from OPERON and dissolved in water to a final concentration of $100 \mathrm{pmol} / \mu 1$.

L-40 WTF4: 5'CACGCTGGGACATACAAATG3'

L-40 WTR3: 5'TCACACAGAATTGTCAGAAAACAG 3'

L-40 MF3: 5'GCGTTGGGAAGACTACAGGA3'

L-40WTF5: 5'CCTTTCCTTCTACCCAGTTTGA3'

L-40MF5: $\quad$ 5'GGAACTCTGTGCTTCGGGT3'

L-40WTR5: 5'AAATTGCAATGACTTAAAGGTAGAA3' 
R6

SB probe1F1:

SB probe1R1:

SB probe2F2:

SB probe2R2:

FafcF2:

Fafc R2:

FafcF4:

FafcR4:

FafcF15:

FafcR15:

UBAF1:

UBAR1:

UBXF1:

UBXR1:

UBAF2

UBAR2:

UBXF2:

UBXR2:

Act F1:

Act R1:

SHIIR:

SHIIIR:

IRESF1:

IRESF2:

IRESF6:

IRESR6:

T7:

T3:

SP6:
5'TCCCTGAAGCCTATTTAGAG3'

5'TACTGCCCTGCAAGACACAG3'

5'ATGTGGCATCGTGAGAAACA3'

5'ATGTTTAAGGCCTGGCACTG3'

5'TCAAATCCAATTCTGCCTGA3'

5'ATGAGCTTCAGATACCTGTGC3'

5'GCATGGCATCATCTACCCTGA3'

5'CTGTACAGACCCGTGAGCAA3'

5'AGAAACCCTTTTCCTTCAAGCA3'

5'GGGGATATCCCGCCATGGCGTCCAACATGG3'

5'CCCCTCGAGGCTGGCCAGGAAACGCCGTTCC3'

5'TTTGGGGATCCACTGTGGGAAGAAGGGCTTC3'

5'TTCCCGAGCTCAAATGTCTTCCTGTTGTTG3'

5'CCCAAGGATCCCCGAAGGAAGAAAATGCTGA3'

5'GGGGGGGAGCTCGCTGCTTCCACCTCTCAGTC3'

5'TTTGGGTCGACTGTGGGAAGAAGAACTTC3'

5'TTCCCGCGGCCGCTGTCTTCCTGTTGTTGAGC3'

5'CCCAAGTCGACGAAGGAAGAAAATGCTGA3'

5'GGGGGGGCGGCCGCTGCTTCCACCTCTCAGTC3'

5'CCCGAATTCGTGCAAAGCCGCCTTTGCTGG3'

5'CCCCTCGAGCTAGAAGCATTTGCGGTGGACG3'

5'GAATAAGGCCGGTGTGCGTT3'

5'CCAACAGGTACCTGACAGAGCAGC3'

5'TAACAAAGAGGACAAGCGGCCT3'

5'TCTTCTTGACGAGCATTCCTAG3'

5'CCCGAAAACCAAAGAAGAAG3'

5'ATTCGATGATCTTCCGGGTA3'

5'TAATACGACTCACTATAGGG3'

5'ATTAACCCTTCACTAAAG3'

5'AGGTGACACTATAGAATAC3' 


\subsubsection{Mouse strains}

L-40 gene-trap line obtained from the group of Prof. Gruss, from MPI Göttingen.

\subsubsection{Antibodies}

Alkaline phosphatase-conjugated anti-goat

FIFC-conjugated anti-mouse

Cy3-conjugated anti-goat

Mouse monoclonal antibody against $a$-tubulin

Mouse monoclonal antibody against actin

Goat polyclonal antibody against Faf1 C terminal (Santa Cruz Biotechnology, Inc.)
(Sigma, Deisenhofen)

(Sigma, Deisenhofen)

(Sigma, Deisenhofen)

(Sigma, Deisenhofen)

(Sigma, Deisenhofen)

\subsubsection{Enzymes}

Restriction enzymes (with supplied buffers)

(Invitrogen, Karlsruhe)

Collagenase (Type II)

(Sigma, Deisenhofen)

Klenow Fragment

(Invitrogen, Karlsruhe)

Proteinase K

(Sigma, Deisenhofen)

Platinum Taq polymerase

(Invitrogen, Karlsruhe)

RNase A

(Qiagen, Hilden)

RNase H

(Invitrogen, Karlsruhe)

RNase inhibitor

(Invitrogen, Karlsruhe)

Superscript-II

(Invitrogen, Karlsruhe)

Taq polymerase

(Invitrogen, Karlsruhe)

T4 DNA ligase

(Promega, Mannheim)

Trypsin

(Invitrogen, Karlsruhe) 


\subsubsection{Kits}

BigDye Terminator Cycle

Endo Free Plasmid Maxi Kit

GST-Bind kit

Megaprime DNA Labeling Kit

Maxi Plasmid Kit

Mega Plasmid Kit

Mini Plasmid Kit

PCR Purification Kit

QIAquick Gel Extraction Kit

RNA Easy Kit

Rediprime $^{\mathrm{TM}}$ II Random Prime

Labeling System

Immunoprecipitation kit (protein $\mathrm{G}$ )

In Situ Cell Death Detection Kit, POD

One step RT PCR kit
(Applied Biosystems)

(Qiagen, Hilden)

(Novagen, Darmstadt)

(Amersham Pharmacia)

(Qiagen, Hilden)

(Qiagen, Hilden)

(Qiagen, Hilden)

(Qiagen, Hilden)

(Qiagen, Hilden)

(Qiagen, Hilden)

(Amersham Pharmacia)

(Qiagen, Hilden)

(Roche, Penzberg)

(Roche, Penzberg)

(Qiagen, Hilden)

\subsubsection{Instruments}

Autoclave

Centrifuge 5415D

Centrifuge 5417R

Biophotometer

DNA Sequencer Modell Megabace 1000

Microscope BX60

GeneAmp PCR System 9600

Histocentre 2 embedding machine

Microtiterplate-Photometer

Molecular Imager FX
(Webeco, Bad Schwartau)

(Eppendorf, Hamburg)

(Eppendorf, Hamburg)

(Eppendorf, Hamburg)

(Amersham, Freiburg)

(Olympus, München)

(Perkin Elmer, Berlin)

(Shandon, Frankfurt aM.)

(BioRad laboratories, München)

(BioRad laboratories, München) 
Phosphoimager Screen

Semi-Dry-Blot Fast Blot

Spectrophotometer Ultraspec 3000

SpeedVac concentrator SVC 100H

Thermomixer 5436

Turboblotter $^{\mathrm{TM}}$

UV Stratalinker $^{\mathrm{TM}} 1800$

X-Ray Automatic Processor Curix 60
(BioRad laboratories, München)

(Biometra, Göttingen)

(Amersham Pharmacia,Freiburg)

(Schütt, Göttingen)

(Eppendorf, Hamburg)

(Schleicher \& Schüll, Dassel)

(Leica, Nußloch)

(Agfa, München)

\subsection{Methods}

\subsubsection{Isolation of nucleic acids}

\subsubsection{Isolation of plasmid DNA}

(Sambrook et al., 1989)

\subsection{Small-scale isolation of plasmid DNA}

(adapted from Birnboim and Doly, 1979)

A single E.coli colony was inoculated in $5 \mathrm{ml}$ of LB medium with the appropriate antibiotic and incubated in a shaker for $16 \mathrm{hrs}$ at $37^{\circ} \mathrm{C}$ with a speed of $160 \mathrm{rpm} .1 \mathrm{ml}$ of this saturated culture was used for making glycerol stocks and rest of the culture was centrifuged at $5000 \mathrm{xg}$ for $15 \mathrm{~min}$. The pellet was resuspended in $150 \mu \mathrm{l}$ of solution P1. The bacterial cells were lysed with $300 \mu$ of P2 solution and then neutralised with $200 \mu$ of solution P3. The precipitated solution was incubated on ice for $15 \mathrm{~min}$, and centrifuged at $13000 \mathrm{xg}$ at $4^{\circ} \mathrm{C}$. The supernatant was transferred into a new tube, and $1 \mathrm{ml}$ of $100 \%$ ethanol was added to precipitate the DNA. It was then stored in ice for $15 \mathrm{~min}$, centrifuged at full speed for $20 \mathrm{~min}$, and finally the pellet was washed with $70 \%$ ethanol and after airdrying dissolved in $30 \mu 1$ of TE buffer. 


$\begin{array}{lll}\text { P1: } & 50 \mathrm{mM} & \text { Tris-Cl, } \mathrm{pH} 8.0 \\ & 10 \mathrm{mM} & \text { EDTA } \\ & 100 \mu \mathrm{g} / \mathrm{ml} & \text { RNase A } \\ \text { P2: } & 200 \mathrm{mM} & \mathrm{NaOH} \\ & 1 \% & \text { SDS } \\ \underline{\mathrm{P} 3}: & 3.0 \mathrm{M} & \text { Potassium acetate, } \mathrm{pH} 5.5\end{array}$

\subsection{Large-scale preparation of plasmid DNA}

A single clone was inoculated in $2 \mathrm{ml} \mathrm{LB}$ medium with appropriate antibiotic as a preculture for $8 \mathrm{hrs}$ in a $37^{\circ} \mathrm{C}$ shaker. In $100 \mathrm{ml} \mathrm{LB}$ medium with appropriate antibiotic, this pre-culture was added in a dilution of $1 / 100$ fold and incubated overnight at $37^{\circ} \mathrm{C}$ with shaking. The saturated culture was centrifuged at $6000 \mathrm{xg}$ for $15 \mathrm{~min}$. The pellet was resuspended in $5 \mathrm{ml}$ of solution P1 and cells were lysed with P2 and P3 as described above. The precipitated solution was centrifuged at $20000 \mathrm{xg}$ for $30 \mathrm{~min}$ at $4^{\circ} \mathrm{C}$. Meanwhile, the column (Qiagen-tip) that was provided with the midi preparation kit was equilibrated with $10 \mathrm{ml}$ of QBT solution. After centrifugation, the lysate was poured into this equilibrated column to allow the DNA to bind with the resin present in the bed of the column. The column was then washed twice with $10 \mathrm{ml}$ of solution QC. Finally, the DNA was eluted with $5 \mathrm{ml}$ of QF solution. To precipitate the DNA, $3.5 \mathrm{ml}$ of isopropanol was added and mixed thoroughly and centrifuged at $14000 \mathrm{xg}$ for $30 \mathrm{~min}$ at $4{ }^{\circ} \mathrm{C}$. The DNA pellet was washed with $70 \%$ ethanol and dissolved in $100 \mu$ of TE.

\begin{tabular}{|c|c|c|}
\hline \multirow[t]{3}{*}{ QBT: } & $750 \mathrm{mM}$ & Sodium chloride \\
\hline & \multicolumn{2}{|c|}{50 mMMOPS pH 7.0} \\
\hline & $15 \%$ & Ethanol \\
\hline & $0.5 \% \mathrm{~T} 1$ & $X-100$ \\
\hline \multirow[t]{3}{*}{ QC: } & $1 \mathrm{mM}$ & Sodium chloride \\
\hline & $50 \mathrm{mM}$ & MOPS pH 7.0 \\
\hline & $15 \%$ & Ethanol \\
\hline
\end{tabular}




$\begin{array}{lll}\text { QF: } & 1.25 \mathrm{M} & \text { Sodium chloride } \\ & 50 \mathrm{mM} & \text { Tris/ } \mathrm{HCl} \mathrm{pH} \mathrm{8,5}\end{array}$

\subsection{Endotoxin free preparation of plasmid DNA}

Endotoxins, also known as lipopolysaccharides or LPS, are cell membrane components of Gram-negative bacteria (e.g., E.coli). During lysis of bacterial cells, endotoxin molecules are released from the outer membrane into the lysate. Endotoxins strongly influence the transfection efficiency of cultured cells. Increased endotoxin levels lead to sharply reduced transfection efficiencies. Endofree plasmid preparation kit integrates endotoxin removal into standard plasmid preparation procedure. The neutralised bacterial lysate was filtered through a QIA filter cartridge (provided in kit) and incubated on ice with a specific Endotoxin Removal buffer (patented by Qiagen). The endotoxin removal buffer prevents LPS molecules from binding to the resin in the columns (QIAGEN-tips), thus allowing purification of DNA containing less than 0.1 endotoxin units per $\mu \mathrm{g}$ plasmid DNA.

\subsubsection{Isolation of genomic DNA}

\subsection{Isolation of genomic DNA from tissue samples}

(Laird et al., 1991)

The method employed was the same as that of Laird et al., (1991). 1 to $2 \mathrm{~cm}$ of the tail from a mouse was incubated in $700 \mu$ of lysis buffer I containing $35 \mu$ proteinase $\mathrm{K}$ $(10 \mu \mathrm{g} / \mu \mathrm{l})$ at $55^{\circ} \mathrm{C}$ overnight in Thermomixer 5436. To the tissue lysate, equal volume of phenol was added, mixed by inverting several times, and centrifuged at $8000 \mathrm{xg}$ for $5 \mathrm{~min}$ at room temperature. After transferring the upper aqueous layer into a new tube, the same procedure was repeated, first with 1:1 ratio of phenol and chloroform and then with chloroform. Finally, the DNA was precipitated with 0.7 volume of isopropanol, washed with $70 \%$ ethanol, and dissolved in 100-200 $\mu \mathrm{l}$ of TE buffer and incubated at $60^{\circ} \mathrm{C}$ for 15 $\min$. 


\subsection{Isolation of genomic DNA from cultured cells}

To isolate the DNA from cultured cells, cells in a 24 well plate were washed with PBS and incubated overnight in $500 \mu \mathrm{l}$ of lysis buffer II at $37^{\circ} \mathrm{C}$. Equal volume of isopropanol was added and mixed for 15 min to precipitate the DNA. After washing with $70 \%$ ethanol, the DNA was transferred into a microcentrifuge cup containing $60 \mu \mathrm{l}$ of TE buffer and incubated at $60^{\circ} \mathrm{C}$ for $15 \mathrm{~min}$.

\subsection{Isolation of total RNA from tissue samples and cultured cells}

Total RNA isolation reagent is an improved version of the single-step method for total RNA isolation. The composition of reagent includes phenol and guanidine thiocyanate in a mono-phase solution. 100-200 mg of tissue sample was homogenised in 1-2 ml of TRI Reagent by using a glass-teflon homogeniser. The sample volume should not exceed $10 \%$ of the volume of reagent used for the homogenisation. To isolate total RNA from cultured cells, $350 \mu \mathrm{l}$ of reagent was added to the Petri dish (6 $\mathrm{cm}$ diameter). Cells were homogenised with a rubber stick and the lysate was transferred into a microcentrifuge tube. The homogenate was incubated at $4^{\circ} \mathrm{C}$ for $5 \mathrm{~min}$ to permit the complete dissociation of nucleoprotein complexes. Then, $0.2 \mathrm{ml}$ of chloroform was added, mixed vigorously, and stored at $4^{\circ} \mathrm{C}$ for $10 \mathrm{~min}$. After centrifugation at $12000 \mathrm{xg}$ for $15 \mathrm{~min}$ at $4^{\circ} \mathrm{C}$, the colourless upper aqueous phase was transferred into a new tube. The RNA was precipitated by adding $0.5 \mathrm{ml}$ of isopropanol. Finally, the pellet was washed twice with $75 \%$ ethanol and dissolved in 80-100 $\mu$ of DEPC- $\mathrm{H}_{2} \mathrm{O}$.

\subsubsection{Determination of nucleic acid concentration}

The concentration of nucleic acids was determined spectrophotometrically by measuring absorption of the samples at $260 \mathrm{~nm}$. The quality of nucleic acids i.e. contamination with salt and protein was checked by the measurements at 230, 280, and $320 \mathrm{~nm}$. The concentration was calculated according to the formula: 


$$
\begin{aligned}
& \qquad \mathrm{C}=(\mathrm{E} 260-\mathrm{E} 320) \mathrm{fc} \\
& \mathrm{C}=\text { concentration of sample }(\mu \mathrm{g} / \mu \mathrm{l}) \\
& \mathrm{E} 260 \quad=\text { ratio of extinction at } 260 \mathrm{~nm} \\
& \mathrm{E} 320 \quad=\text { ratio of extinction at } 320 \mathrm{~nm} \\
& \mathrm{f} \quad=\text { dilution factor } \\
& \mathrm{c} \quad=\text { concentration }(\text { standard }) / \mathrm{absorption}(\text { standard) } \\
& \text { For double stranded DNA: c }=0.05 \mu \mathrm{g} / \mu \mathrm{l} \\
& \text { for RNA : c }=0.04 \mu \mathrm{g} / \mu \mathrm{l} \\
& \text { for single stranded DNA : c }=0.03 \mu \mathrm{g} / \mu \mathrm{l}
\end{aligned}
$$

\subsubsection{Gel electrophoresis}

Gel electrophoresis is the technique by which mixtures of charged macromolecules, especially nucleic acids and proteins, are separated in an electrical field according to their mobility which is directly proportional to macromolecule's charge to mass ratio.

\subsubsection{Agarose gel electrophoresis of DNA}

Agarose gels are used to electrophorese nucleic acid molecules from as small as 50 bases to more than $20 \mathrm{~kb}$, depending on the concentration of the agarose. Usually, $1 \mathrm{~g}$ of agarose was added to $100 \mathrm{ml}$ of $0.5 \mathrm{x}$ TBE buffer and boiled in the microwave to dissolve the agarose, then cooled down to about $60^{\circ} \mathrm{C}$ before adding $3 \mu \mathrm{l}$ of ethidium bromide $(10$ $\mathrm{mg} / \mathrm{ml}$ ). This $1 \%$ agarose gel was poured into a horizontal gel chamber.

\subsubsection{Agarose gel electrophoresis of RNA}

(Hodge, 1994)

Single-stranded RNA molecules often have complementary regions that can form secondary structures. Therefore, RNA was run on a denaturing agarose gel that contained formaldehyde, and before loading, the RNA was pre-treated with formaldehyde and 
formamide to denature the secondary structure of RNA. $1.25 \mathrm{~g}$ of agarose was added to 100 $\mathrm{ml}$ of $1 \mathrm{x}$ MOPS Buffer and dissolved by heating in a microwave. After cooling it to about $50^{\circ} \mathrm{C}, 25 \mathrm{ml}$ of formaldehyde $(37 \%)$ was added, stirred and poured into a horizontal gel chamber.

RNA samples were treated as follows:

$$
\begin{aligned}
& 10-20 \mu \mathrm{g} \text { RNA } 2 \mu \mathrm{l} \\
& \text { 10x MOPS Buffer } \\
& 3 \mu 1 \text { Formaldehyde } \\
& 8 \mu 1 \text { Formamide }(40 \%) \\
& 1.5 \mu 1 \text { Ethidium bromide }
\end{aligned}
$$

Samples were denatured at $65^{\circ} \mathrm{C}$ for $10 \mathrm{~min}$ and chilled on ice before loading into the gel. The gel was run at $40 \mathrm{~V}$ at $4^{\circ} \mathrm{C}$ for about $12 \mathrm{hrs}$.

\subsubsection{SDS-PAGE for the separation of proteins}

(Laemmli, 1970)

SDS gel electrophoresis is a method for separating proteins according to molecular weight. The proteins are denatured and rendered monomeric by boiling in the presence of reducing agents ( $\beta$-mercaptoethanol or dithiotheitol) and negatively charged detergent (SDS). The proteins, which normally differ according to their charges, are all coated with the SDS molecules, which are negatively charged. Hence, all the proteins in the sample become negatively charged and achieve constant charge to mass ratio. In this way, the separation is according to the size of the proteins. A SDS-PAGE consists of two gels; firstly, a 10-12\% separating gel was poured. In order to achieve a smooth boundary between separating and stacking gel, the separating gel was covered with a layer of water. After polymerisation of the separating gel, a $4 \%$ stacking gel was poured over it. The samples were boiled in sample buffer for $10 \mathrm{~min}$ at $95^{\circ} \mathrm{C}$ before loading into the gel. The gel was run at $15 \mathrm{~mA}$ for $1 \mathrm{hr}$ and then at a constant current of $30 \mathrm{~mA}$. 


\subsubsection{Isolation of DNA fragments after agarose gel electrophoresis}

\subsubsection{QIAquick gel extraction method}

This method is designed to extract and purify DNA of $70 \mathrm{bp}$ to $10 \mathrm{~kb}$ in length from agarose gels. Up to $400 \mathrm{mg}$ agarose can be processed per spin column. The principle of this method depends on selective binding of DNA to uniquely designed silica-gel membranes. To the excised DNA fragment from agarose, and 3 volumes of QG buffer was added then incubated at $50^{\circ} \mathrm{C}$ for $10 \mathrm{~min}$. After the gel slice was dissolved completely, it was applied over a QIAquick column and centrifuged for $1 \mathrm{~min}$. The flow through was discarded and the column was washed with $0.75 \mathrm{ml}$ of PE buffer. After drying the column, it was placed into a fresh microcentrifuge tube. To elute DNA, $50 \mu$ of EB buffer was applied to the centre of the QIAquick membrane and centrifuged for $1 \mathrm{~min}$.

\subsubsection{Enzymatic modifications of DNA}

\subsubsection{Restriction of DNA}

Restriction enzyme digestions were performed by incubating double-stranded DNA with an appropriate amount of restriction enzyme in its respective buffer as recommended by the supplier, and at the optimal temperature for the specific enzyme. Standard digestions included 2-10 U enzyme per microgram of DNA. These reactions were usually incubated for 1-3 hrs to ensure complete digestion at the optimal temperature for enzyme activity, which was typically $37^{\circ} \mathrm{C}$. For genomic DNA digestion, the reaction solution was incubated overnight at $37^{\circ} \mathrm{C}$.

\subsubsection{Ligation of DNA fragments}

The ligation of an insert DNA into a vector (digested with appropriate restriction enzyme) was carried out in the following reaction mix:

30 ng vector DNA (digested)

50-100 ng insert DNA (1:3, vector: insert ratio) 


$$
\begin{aligned}
& 1 \mu \mathrm{l} \text { ligation buffer }(10 \mathrm{x}) \\
& 1 \mu \mathrm{l} \text { T4 DNA ligase }(5 \mathrm{U} / \mu \mathrm{l}) \\
& \text { in a total volume of } 10 \mu \mathrm{l}
\end{aligned}
$$

Blunt-end ligations were carried out at $16^{\circ} \mathrm{C}$ for overnight, whereas overhang-end ligations were carried out at room temperature for 2-4 hrs.

\subsubsection{TA-Cloning}

(Clark, 1988; Hu, 1993)

Taq polymerase and other DNA polymerases have a terminal transferase activity that results in the non-template addition of a single nucleotide to the $3^{\prime}$ ends of PCR products. In the presence of all $4 \mathrm{dNTPs}$, dATP is preferentially added. This terminal transferase activity is the basis of the TA- cloning strategy. For cloning of PCR products, the pGEM-T or pGEM-T Easy vector systems that has $5^{\circ} \mathrm{T}$ overhangs were used.

The followings were mixed:

$$
\begin{aligned}
& 50 \text { ng of pGEM-T Easy Vector } \\
& 150 \mathrm{ng} \text { PCR product } \\
& 1 \mu \mathrm{l} \text { of T4 DNA Ligase buffer (x10) } \\
& 1 \mu \mathrm{l} \text { of T4 DNA Ligase } \\
& \text { in a total volume of } 10 \mu \mathrm{l}
\end{aligned}
$$

The content was mixed by pipetting and the reaction was incubated overnight at $16^{\circ} \mathrm{C}$.

\subsubsection{Preparation of competent E.coli bacteria}

(Dagert and Ehrlich, 1979)

The competent bacterial cells are generated by a physical cell wall modification that facilitates DNA uptake. LB medium $(100 \mathrm{ml})$ was inoculated with a single colony of E.coli (strain DH5 $\alpha$ ) and the culture was grown at $37^{\circ} \mathrm{C}$ to $\mathrm{OD} 600=0.6$. Bacteria were centrifuged $\left(10 \mathrm{~min}, 4^{\circ} \mathrm{C}, 3000 \mathrm{xg}\right)$ and the pellet was resuspended in $50 \mathrm{ml}$ of sterile 50 $\mathrm{mM} \mathrm{CaCl} 2$ solution $\left(4^{\circ} \mathrm{C}\right)$ and incubated on ice for $30 \mathrm{~min}$. The suspension of bacteria 
was centrifuged $\left(10 \mathrm{~min}, 4^{\circ} \mathrm{C}, 3000 \mathrm{xg}\right)$ and the pellet was resuspended in $10 \mathrm{ml}$ of sterile $50 \mathrm{mM} \mathrm{CaCl}_{2}\left(4^{\circ} \mathrm{C}\right)$ with $15 \%$ glycerol. The mixture was dispensed into aliquots of $100 \mu \mathrm{l}$ and stored at $-80^{\circ} \mathrm{C}$. Mostly, competent $\mathrm{DH} 5 \alpha$ were purchased from Invitrogen.

\subsubsection{Transformation of competent bacteria}

(Ausubel et al., 1994)

Transformation of bacteria was done by gently mixing one aliquot of competent bacteria $(50 \mu 1)$ with $10 \mu \mathrm{l}$ of ligation reaction. After incubation for $30 \mathrm{~min}$ on ice, bacteria were heat shocked for $45 \mathrm{sec}$ at $42^{\circ} \mathrm{C}$, cooled down for 2 min on ice. After adding $450 \mu \mathrm{l}$ of LB medium, bacteria were incubated at $37^{\circ} \mathrm{C}, 200 \mathrm{rpm}$ for $1 \mathrm{hr}$ to allow recovery of heat shocked bacteria and then plated out on LB-agar plates.

\subsubsection{Polymerase Chain Reaction (PCR)}

The polymerase chain reaction (PCR) represents the single most important technique in the field of molecular biology. It is a very sensitive and powerful technique (Saiki et al., 1988) that is widely used for the exponential amplification of specific DNA sequences in vitro by using sequence specific synthetic oligonucleotides (primers). The general principle of PCR starts from a pair of oligonucleotide primers that are designed so that a forward or sense primer directs the synthesis of DNA towards a reverse or antisense primer, and vice versa. During the PCR, the Taq DNA polymerase (a heat stable polymerase) (Chien et al., 1976) catalyses the synthesis of a new DNA strand that is complementary to a template DNA from the 5' to 3 ' direction by a primer extension reaction, resulting in the production of the DNA region flanked by the two primers. It allows the rapid and unlimited amplification of specific nucleic acid sequences that may be present at very low concentrations in very complex mixtures. 


\title{
2.2.8.1 PCR amplification of DNA fragments
}

The amplification cycles were performed in an automatic thermocycler. The PCR reaction contains in general, the following substances:

\begin{tabular}{|c|c|}
\hline $10 \mathrm{ng}$ & DNA \\
\hline $1 \mu 1$ & forward primer (10pmol) \\
\hline $1 \mu \mathrm{l}$ & reverse primer (10pmol) \\
\hline $1 \mu 1$ & $10 \mathrm{mM}$ dNTPs \\
\hline $5 \mu \mathrm{l}$ & 10x PCR buffer \\
\hline $1.5 \mu l$ & $50 \mathrm{mM} \mathrm{MgCl}_{2}$ \\
\hline $0.5 \mu l$ & Taq DNA Polymerase $(5 \mathrm{U} / \mu \mathrm{l})$ \\
\hline Up to $50 \mu 1$ & $\mathrm{H}_{2} \mathrm{O}$ \\
\hline
\end{tabular}

The reaction mixture was placed in a $200 \mu \mathrm{l}$ reaction tube and placed in a thermocycler. Thermal cycling was carried out for 35 cycles with denaturation at $97^{\circ} \mathrm{C}$ for $30 \mathrm{sec}$, annealing at $55-60^{\circ} \mathrm{C}$ for $30 \mathrm{sec}$, and extension at $72^{\circ} \mathrm{C}$ for $1 \mathrm{~min}$.

\subsubsection{Reverse transcription PCR (RT-PCR)}

RT-PCR generates cDNA fragments from RNA templates and is very useful to determine the expression of genes in specific tissues or in different development stages. 1-5 $\mu \mathrm{g}$ of total RNA was mixed with $1 \mu \mathrm{l}$ of oligo $(\mathrm{dT})_{18}$ primer $(10 \mathrm{pmol} / \mu \mathrm{l})$ in a total volume of $12 \mu \mathrm{l}$. To avoid the possible secondary structure of the RNA, which might interfere with the synthesis, the mixture was heated to $70^{\circ} \mathrm{C}$ for $10 \mathrm{~min}$, and then quickly chilled on ice. After a brief centrifugation, the followings were added to the mixture:

\author{
$4 \mu 15 x$ First strand buffer \\ $2 \mu 10.1$ M DTT \\ $1 \mu 1$ 10mM dNTPs \\ $1 \mu \mathrm{R} \operatorname{Rasin}(10 \mathrm{U} / \mu \mathrm{l})$
}


The content of the tube was mixed gently and incubated at $42^{0} \mathrm{C}$ for $2 \mathrm{~min}$. Then, $1 \mu 1$ of reverse transcriptase enzyme (Superscript II) was added and incubated at $42^{\circ} \mathrm{C}$ for 50 min for the first strand cDNA synthesis. Next, the reaction was inactivated by heating at $70^{\circ} \mathrm{C}$ for $15 \mathrm{~min}$. One $\mu \mathrm{l}$ of the first strand reaction was used for the PCR reaction $(2.2 .8 .1)$.

\subsubsection{One-Step RT-PCR}

To obtain specific RT-PCR products, the QIAGEN OneStep RT-PCR kit was employed which contains optimized components that allow both reverse transcription and PCR amplification to take place in what is commonly referred to as a "one-step" reaction.

Master mix;

5 x Qiagen OneStep RT-PCR buffer

dNTP mix (containing $10 \mathrm{mM}$ of each dNTP)

Forward primer $(10 \mathrm{pmol})$

Reverse primer (10 pmol)

Qiagen OneStep RT-PCR Enzyme Mix

RNase inhibitor (20 units per $1 \mu 1$ )

RNase-free water $\underline{\text { Per reaction }}$

$10 \mu 1$

$2 \mu 1$

$1 \mu 1$

$1 \mu 1$

$2 \mu 1$

$1 \mu 1$

$31 \mu 1$

$2 \mu \mathrm{l}(2 \mu \mathrm{g})$ of total RNA isolated from mouse tissues was added to $48 \mu \mathrm{l}$ of prepared Master mix in a PCR tube, the sample was placed in the thermal cycler and the RT-PCR program run according to the user manual. Reverse transcription reaction was performed at $50^{\circ} \mathrm{C}$ for $30 \mathrm{~min}$. To denaturate the DNA-RNA hybrid molecules, the reaction was heated to $94^{\circ} \mathrm{C}$ for $10 \mathrm{~min}$. Thermal cycling was carried out for 35 cycles with denaturation at $94^{\circ} \mathrm{C}$ for $30 \mathrm{sec}$, annealing at $56^{\circ} \mathrm{C}-60^{\circ} \mathrm{C}$ for $40 \mathrm{sec}$, and extension at $72^{\circ} \mathrm{C}$ for $1 \mathrm{~min}$. After the amplification step, the sample was checked on an agarose gel. 


\subsubsection{Protein methods}

\subsubsection{Isolation of total proteins}

$100 \mathrm{mg}$ of tissue was homogenized in $500 \mu \mathrm{l}$ Lysis buffer A with a Teflon-glass headed pestle. Then, homogenization samples were handled with ultrasound on ice $2 \times 2 \mathrm{~min}$. The samples were centrifuged at $8000 \mathrm{xg}$ for $20 \mathrm{~min}$ at $4^{\circ} \mathrm{C}$ and supernatant was distributed in several microcentrifuge tubes. The tubes were frozen in liquid nitrogen and stored at $-80^{\circ} \mathrm{C}$. $5 \times 10^{6}$ cells $/ \mathrm{ml}$ were washed with cold phosphate buffered saline and resuspended in $50 \mu \mathrm{l}$ of lysis buffer B. The cells were allowed to swell on ice for $30 \mathrm{~min}$, after which the cells were resuspended in $300 \mu \mathrm{l}$ of lysis buffer B. After homogenization, samples were handled with ultrasound on ice $2 \times 30 \mathrm{sec}$ and centrifuged at $24000 \mathrm{x} \mathrm{g}$ for $20 \mathrm{~min}$ at $4{ }^{\circ} \mathrm{C}$. The protein extract was either used immediately or stored at $-80^{\circ} \mathrm{C}$ for later use.

\subsubsection{Determination of protein concentration}

(Bradford, 1976)

To determine the protein concentration, Bio-Rad protein assay was employed which is a dye-binding assay based on the differential colour change of a dye in response to various concentrations of protein. The assay is based on the observation that the absorbance maximum for an acidic solution of Coomassie Blue G-250 shifts from 494 to $595 \mathrm{~nm}$ when the binding to protein occurs. The BSA stock solution of $1 \mathrm{mg} / \mathrm{ml}$ was diluted in order to obtain standard dilutions in range of $10 \mu \mathrm{g} / \mathrm{ml}$ to $100 \mu \mathrm{g} / \mathrm{ml}$. The Bio-Rad's color reagent was diluted 1:5 with $\mathrm{H}_{2} \mathrm{O}$, and filtered through $0.45 \mu \mathrm{m}$ filters. In a 96-well microtiter plate, $20 \mu \mathrm{l}$ of each standard dilution and the samples to be measured were pipetted with $280 \mu \mathrm{l}$ of the color reagent. The absorption of the colour reaction was measured at $595 \mathrm{~nm}$ in a microplate reader (Microplate Reader 450, Bio-Rad). 


\subsubsection{Blotting techniques}

\subsubsection{Southern blotting of DNA to nitrocellulose filters}

(Southern, 1975)

In Southern blotting, the transfer of denatured DNA from agarose gels to nitrocellulose membrane is achieved by capillary flow. 20x SSC buffer, in which nucleic acids are highly soluble, is drawn up through the gel into the nitrocellulose membrane, taking with it the single-stranded DNA that becomes immobilised in the membrane matrix.

After electrophoresis of DNA, the gel was treated with $0.25 \mathrm{M} \mathrm{HCl}$ for depurination. It was followed by denaturation solution for $30 \mathrm{~min}$ and $45 \mathrm{~min}$ in neutralization solution. The transfer of the DNA to the nitrocellulose membrane was done in a Turbo-Blot-apparatus (Schleicher \& Schuell, Dassel). About 20 Whatman filter papers (GB 003) were layered on a Stack Tray, followed by 4 Whatman filter papers (GB 002) and 1 Whatman filter paper GB 002 soaked with $2 x$ SSC. The equilibrated nitrocellulose filter that was also soaked with 2x SSC was laid on the top. The agarose gel, which was treated as described above, was placed on the filter and was covered with 3 Whatman filter papers GB 002 soaked with 2x SSC. The buffer tray was placed and filled with 20x SSC. Finally a wick, which was soaked with 20x SSC, and the wick cover were put on the top of the blot. The transfer was carried out for overnight. Finally, after disassembling of the blot, the filter was washed briefly in 2x SSC and the DNA was fixed onto the filter by either baking it at $80^{\circ} \mathrm{C}$ for 2 hrs or by UV-crosslinking in UV Stratalinker 1800.

\subsubsection{Northern blotting of RNA onto nitrocellulose filter}

For the transfer of RNA onto a nitrocellulose filter, the same procedure as described above (2.2.10.1) was performed. In this case, however, the gel does not need to be denatured, but was transferred directly onto the filter. 


\subsubsection{Western blotting of protein onto PVDF membrane}

(Gershoni and Palade, 1982)

Anode I buffer

Anode II buffer

Cathode buffer
0.3 M Tris/HCl, pH 10.4

$20 \%$ Methanol

25 mM Tris/HCl, pH 10.4

$20 \%$ Methanol

$40 \mathrm{mM} \varepsilon$-Aminocaproic acid

25 mM Tris/HCl, pH 9.4

$20 \%$ Methanol

After electrophoresis of proteins on a SDS-PAGE, the gel and the PVDF membrane, which was cut at the size of the gel, was first moistened with methanol and then equilibrated in anode II buffer. Six pieces of GB004 Whatman filter paper were also cut at the size of the gel. Two pieces of filter papers were soaked in anode buffer I and one paper in anode II buffer. First, the papers soaked with anode I buffer were placed on semi dry transfer machine's lower plate and than papers soaked with anode II buffer were placed over it. The equilibrated membrane was placed over them and then the gel were placed avoiding any air bubbles. Another three Whatman papers soaked with cathode buffer was placed over to complete the sandwich model. The upper plate was placed over this sandwich and the transfer was carried out at $3.5 \mathrm{~mA} / \mathrm{cm}^{2}$ for $1 \mathrm{hr}$.

\section{Membrane staining}

Membrane was stained with Coomassie blue for $30 \mathrm{~min}$ in room temperature.

Coomassie blue: $\quad-0.1 \%$ coomassie

- $90 \%$ Methanol

$-10 \% \mathrm{CH}_{2} \mathrm{COOH}$

Destaining of the membrane.

Destaining solution: - $40 \%$ Methanol 
$-10 \% \mathrm{CH}_{2} \mathrm{COOH}$

-up to $\mathrm{H}_{2} \mathrm{O}$

\subsubsection{1 "Random Prime” method for generation of ${ }^{32} \mathrm{P}$ labeled DNA}

(Denhardt, 1966; Feinberg and Vogelstein, 1989)

Rediprime $^{\mathrm{TM}}$ II Random Prime Labeling System (Amersham Pharmacia) was used for labelling of DNA probes. The method depends on the random priming principle developed by Feinberg and Vogelstein (1989). The reaction mix contained dATP, dGTP, dTTP, Klenow fragment (4-8 U) and random oligodeoxyribonucleotides. Firstly, 25-50 ng of DNA were denatured in a total volume of $46 \mu$ at boiling water for $10 \mathrm{~min}$ and quick chilled in ice for $5 \mathrm{~min}$. After pipetting the denatured probe in Rediprime ${ }^{\mathrm{TM}}$ II Random Prime Labeling System cup, $4 \mu \mathrm{l}$ of $\left[\alpha-{ }^{32} \mathrm{P}\right] \mathrm{dCTP}(3000 \mathrm{Ci} / \mathrm{mmol})$ were added to the reaction mixture. The labelling reaction was carried out at $37^{\circ} \mathrm{C}$ for $1 \mathrm{hr}$. The labelled probe was purified from uncorporated $\left[\alpha-{ }^{32} \mathrm{P}\right] \mathrm{dCTP}$ by using microspin columns (Amersham Pharmacia).

\subsubsection{Non-radioactive dye terminator cycle sequencing}

Non-radioactive sequencing was performed with the Dye Terminator Cycle SequencingKit (ABI PRISM). The reaction products were analysed with automatic sequencing equipment, MegaBace DNA Sequencer. For the sequencing reaction, four different dye labelled dideoxy nucleotides were used (Sanger et al., 1977), which, when exposed to an argon laser, emit fluorescent light which can be detected and interpreted. The reaction was carried out in a total volume of $10 \mu \mathrm{l}$ containing $1 \mu \mathrm{g}$ plasmid DNA or 100-200 ng purified PCR products, 10 pmol primer and $4 \mu \mathrm{l}$ reaction mix (contains dNTPs, dideoxy dye terminators and Taq DNA polymerase). Elongation and chain termination take place during the following program in a thermocycler: 4 min denaturation followed by 25 cycles at $95^{\circ} \mathrm{C}, 30 \mathrm{sec} ; 55^{\circ} \mathrm{C}, 15 \mathrm{sec}$, annealing; $60^{\circ} \mathrm{C}, 4 \mathrm{~min}$, elongation. After the sequencing reaction, the DNA was precipitated with $1 / 10$ volume $3 \mathrm{M}$ sodium acetate and 2.5 volume 
$100 \%$ ethanol and washed in $70 \%$ ethanol. The pellet was dissolved in $4 \mu$ l of loading buffer, denatured at $95^{\circ} \mathrm{C}$ for $3 \mathrm{~min}$, and finally loaded into the sequence gel.

\subsubsection{Hybridisation of nucleic acids}

(Denhardt, 1966)

The membrane to be hybridised was equilibrated in $2 \mathrm{x}$ SSC and transferred to a hybridisation bottle. After adding $10 \mathrm{ml}$ of hybridisation solution and sheared denatured salmon DNA, the membrane was incubated for $2 \mathrm{hrs}$ in the hybridization oven at an appropriate temperature, which was usually $65^{\circ} \mathrm{C}$. Then, the labelled probe was denatured at $95^{\circ} \mathrm{C}$ for $10 \mathrm{~min}$, quick by chilled, and added to the hybridisation solution. The hybridisation was carried out overnight in the oven. Next day, the filter was washed for 10 min with $2 \mathrm{x}$ SSC at room temperature. Finally, was washed with $0.2 \mathrm{x}$ SSC containing 0.1 $\%$ SDS at the hybridisation temperature. After drying the filter, it was sealed in Saran wrap and exposed to autoradiography overnight at $-80^{\circ} \mathrm{C}$ or to Phosphoimager screen for $1-4 \mathrm{hrs}$. The film was developed in X-Ray Automatic Processor Curix 60 or screen was scanned in Phosphoimager. For quantification of detected bands, the program Quantity One (Bio-Rad) was used.

\subsubsection{Histological techniques}

\subsection{Tissue preparation for paraffin-embedding}

The freshly prepared tissues were fixed in Bouin's solution or $4 \%(\mathrm{w} / \mathrm{v})$ paraformaldehyde for $24 \mathrm{hrs}$ to prevent alterations in the cellular structure. The tissue to be embedded in paraffin should be free of water. The dehydration process was accomplished by passing the tissue through a series of increasing alcohol concentrations. For this purpose, the tissue was let in $30 \%, 70 \%, 90 \%$, and $100 \%(2 \mathrm{x})$ ethanol for $1 \mathrm{hr}$ room temperature. Later, the alcohol 
was removed from the tissue by incubating it in methylbenzoat overnight. It was then incubated in $5 \mathrm{ml}$ of histoclear (Xylol) for 10-30 min at room temperature. The second histoclear was not discarded but $5 \mathrm{ml}$ of paraplast were added and the incubation was continued at $60^{\circ} \mathrm{C}$ for another $30 \mathrm{~min}$. The histoclear and paraffin mixture was discarded and the tissue was further incubated in $5 \mathrm{ml}$ of paraplast at $60^{\circ} \mathrm{C}$ overnight. Before embedding, the paraffin was changed at least three times. Finally, the tissue was placed in embedding mold and melted paraffin was poured into the mold to form a block. The block was allowed to cool and was then ready for sectioning.

\subsection{Sections of the paraffin block}

The paraffin blocks were pre-cut to the optimal size and clamped into the microtome (Hn 40 Ing., Nut hole, Germany). The cut-thickness of the section was for $5 \mu \mathrm{m}$. The sections were floated on $40^{\circ} \mathrm{C}$ water to allow actual spread and subsequently put onto pre-treated slides. In order to achieve a better adhesion of the sections, the slides were treated with a drop of serum-formalin. A fine brush was used to transfer the sections to the pre-treated slides. After complete evaporation at $37^{\circ} \mathrm{C}$ for $2-5$ days, slides were stored at $4{ }^{\circ} \mathrm{C}$ for further analysis.

\subsection{Preparation of paraffin sections}

For X-gal staining, tissues were dehydrated for $1 \mathrm{hr}$ each in an increasing series of ethanol $(50 \%, 70 \%, 90 \%$, and $96 \%)$. For the paraffin embedding, the alcohol must be removed from the tissue, which was achieved with an overnight incubation in methyl benzoate. Washing twice for $10 \mathrm{~min}$ with Roticlear, the methyl benzoate was also removed. The embedding was done with a paraffin mixture with the commercial name of ParaplastTM, which contains DMSO for a better infiltration in the tissue. The jars used in the procedure are temperated at $60^{\circ} \mathrm{C}$. The ParaplastTM was melt at $60^{\circ} \mathrm{C}$ in an oven for $1 \mathrm{hr}$. The Roticlear was replaced with a 1:1 mix of Roticlear and ParaplastTM, and the tissue was incubated at $60^{\circ} \mathrm{C}$ in this medium twice for $20 \mathrm{~min}$. Then, the tissue was incubated $2 \times 20$ min in ParaplastTM alone. The tissue was transferred to the embedding mould, which was 
filled with liquid ParaplastTM and laid at room temperature to solidify. After this, the paraffin block was cut and mounted onto the microtome to make sections of 2-10 $\mu \mathrm{m}$. The sections were mounted on superfrost slides. The paraffin sections were then stored at $4^{\circ} \mathrm{C}$. Tissue sections were incubated twice for $10 \mathrm{~min}$ in Roticlear to remove the paraffin. Then, sections were re-hydrated in a decreasing ethanol series $(100 \%, 96 \%, 70 \%, 50 \%$, and $30 \%)$ for 2 min each, finally washed in PBS and air-dried. Now the sections were ready for light microscopical analysis.

\subsection{X-gal staining}

\section{X-gal staining of adult mouse tissues}

A histochemical staining procedure for $E$. coli $\beta$-galactosidase activity in adult mouse tissue was used to detect Lac $\mathrm{Z}$ expression. Tissues were rinsed in cold PBS and fixed in FixA solution for $30 \mathrm{~min}$ on ice with shaking. Than the tissues were washed again in PBS and fixed in FixB solution for $1 \mathrm{hr}$ on ice shaking. After final washing with PBS, tissues were incubated overnight in X-gal staining solution at $30^{\circ} \mathrm{C}$ under dark condition.

FixA

$1 \% \mathrm{v} / \mathrm{v}$ formaldehyde

$0.2 \% \mathrm{v} / \mathrm{v}$ glutaraldehyde

$0.02 \% \mathrm{v} / \mathrm{v} \mathrm{NP}-40$

in PBS

FixB

$1 \% \mathrm{v} / \mathrm{v}$ formaldehyde

$0.2 \% \mathrm{v} / \mathrm{v}$ glutaraldehyde

$0.2 \% \mathrm{v} / \mathrm{v} \mathrm{NP}-40$

$0.1 \% \mathrm{w} / \mathrm{v}$ sodium deoxycholate

in PBS 


\begin{tabular}{|c|c|}
\hline X-gal staining solution & $1 \mathrm{mg} / \mathrm{ml} \mathrm{X-gal}$ \\
\hline & $5 \mathrm{mM}$ potassium ferricyanide \\
\hline & $5 \mathrm{mM}$ potassium ferrocyanide \\
\hline & $2 \mathrm{mM} \mathrm{MgCl}_{2}$ \\
\hline & in PBS \\
\hline
\end{tabular}

\subsection{Immunofluorescence staining of mouse testes and tissues}

Fixation and subsequent treatment of mouse testicular tissue was performed as described in section 2.2.15.1. Adult mouse testis cross sections $(5-10 \mu \mathrm{m})$ were dewaxed with roticlear solution and rehydrated by descending ethanol concentrations. For immunofluorescence staining, sections were washed in PBS and were then incubated with a blocking solution containing 5\% horse serum and $0.02 \%$ Tween-20 in PBS for $1 \mathrm{hr}$ at room temperature. The testis sections were incubated with affinity-purified primary polyclonal antibody for $16 \mathrm{hrs}$ at $4^{\circ} \mathrm{C}$. The tissue sections were rinsed four times in PBS and subsequently incubated with (Cy3)-conjugated mouse anti goat $\operatorname{IgG}(1: 100)$ for $1 \mathrm{hr}$ at room temperature. After the tissue sections were washed three times with PBS, the nuclei were counterstained with DAPI. Immunostaining of the sections was examined using a fluorescence equipped microscope (BX60; Olympus).

\subsection{Immunofluorescence staining of cells}

Cells were fixed in 4\% paraformaldehyd in PBS for $20 \mathrm{~min}$ at room temperature, followed by $100 \%$ methanol at $-20^{\circ} \mathrm{C}$ for $5 \mathrm{~min}$. The cells were rinsed in PBS. An initial blocking step was performed with the blocking solution (2\% horse serum and $0.5 \%$ Triton $\mathrm{X}-100$ in PBS) for $1 \mathrm{hr}$. A mouse anti-goat Fafl was applied for overnight at $4^{\circ} \mathrm{C}$ in a dilution of 1:100. Cells were subsequently incubated with Cy3- conjugated mouse anti-goat IgG for 1 $\mathrm{hr}$ at room temperature. One drop of mounting medium with DAPI was dispensed onto the slides after washing with PBS. Fluorescent cells were visualised with Olympus BX60 microscope using $20 \mathrm{X}$ or $60 \mathrm{X}$ Neofluor lens, photographed using digital camera and analysed by analysis 3.0 soft imaging system. 


\subsection{Immunocytochemical staining of germ cell suspensions.}

Germ cell suspensions were prepared from mouse testes by using the collagenase/trypsin method according to published procedure (Romrell et al., 1976). Testes from 60 days old mice were collected in serum-free culture medium, rinsed in 0.1 M PBS, pH 7.2. After removal of the tunica albuginea, seminiferous tubules were enzymatically dissociated by the addition of $1 \mathrm{ml}$ collagenase $(1 \mathrm{mg} / \mathrm{ml})$. The slurry maintained at $37^{\circ} \mathrm{C}$ for $15 \mathrm{~min}$, was triturated every $5 \mathrm{~min} .5 \mathrm{ml}$ of Hank's solution was added and then spun at $350 \mathrm{x} \mathrm{g}$ to sediment the dissociated cells. The pellet was resuspended in $3 \mathrm{ml}$ trypsin and then trypsin was inactivated by adding $5 \mathrm{ml}$ FKS. The slurry was passed through $80 \mu \mathrm{m}$ nylon mesh. The filtrate was spun at $350 \mathrm{x}$ g to sediment the cells. Cells were resuspended in $1 \mathrm{ml}$ PBS and spread onto superfrost slides, air-dried and fixed in $100 \%$ methabol for $10 \mathrm{~min}$. The immunocytochemical staining procedure was performed as described (2.2.15.4).

\subsubsection{TUNEL-assay for detection of apoptotic cells.}

Testes were fixed in 4\% paraformaldehyde and embedded in paraffin. Sections were cut at $5 \mu \mathrm{m}$. TdT- mediated nick labeling (TUNEL) staining was performed using the In Situ Cell

Death Detection Kit (Roche Diagnostic GmbH, Mannheim) according to the manufacturer's instructions. After rehydration, the sections were incubated in $2 \times$ SSC at $80^{\circ} \mathrm{C}$ for $20 \mathrm{~min}$ followed by washing twice with water and once with proteinase $\mathrm{K}$ buffer (29 mM Tris/HCl, pH7.5, 2mM CaCl) for 5 min each. The slides were then treated with proteinase $\mathrm{K}(10 \mu \mathrm{g} / \mathrm{ml})$ at $37^{\circ} \mathrm{C}$ for $30 \mathrm{~min}$. An aliquot of 3'-end labeling reaction mixture containing $4 \mu \mathrm{l}$ of $5 \mathrm{x}$ terminal deoxynucleotidyl transferase (TdT) buffer, $0.1 \mu 1$ of digoxigenin-11-ddUTP $(10 \mathrm{nmol} / \mu \mathrm{l}) 0,2 \mu \mathrm{l}$ of ddATP $(5 \mathrm{mM}), 1 \mu \mathrm{l}$ of TdT and $14.7 \mu \mathrm{l}$ nuclease-free water was applied to one section. The slides were kept in a humidified box, incubated at $37^{\circ} \mathrm{C}$ for $1 \mathrm{~h}$, and then washed three times with TBST buffer $(10 \mathrm{mM}$ Tris/ $\mathrm{HCl}$, $\mathrm{pH}-8.0,100 \mathrm{mM} \mathrm{NaCl}$, and $0.1 \%$ Tween-20) for $20 \mathrm{~min}$ each. An anti-digoxigeninhorseradish peroxidase monoclonal antibody (DAKO, 1:200 dilution in TBST containing $1 \%$ BSA) was applied, and the slides were incubated in the humidified box at room temperature for $1 \mathrm{~h}$ and then washed three times with TBST for 5 min each time. Finally, 
the labeled cells were visualized by 3,3'-diaminobenzidine tetrahydrochloride for $0.5-2$ $\min$.

\subsubsection{Culture and immunostaining of preimplantation embryos}

\subsubsection{Superovulation}

Seven to eight week old female mice were superovulated by intraperitoneal injections of 5 IU of pregnant mare's serum gonadotropin (PMSG, Sigma St Louis, MO, USA) followed 44-48 hrs later by 5 IU of human chorionic gonadotrophin (HCG; Sigma). After the second injection, females were housed overnight with males and were checked by a vaginal plug the following morning. The E0.5 was considered to be $12^{00}$ noon at the day of vaginal plug.

\subsubsection{Recovery of preimplantation embryos}

Matings were set up between superovulated female and male Faf1 GT/+ mice. Pregnant females were killed by cervical dislocation at 0.5 days pc. 1-cell stage embryos (E-05) were isolated from oviducts and washed through several large volume changes of M2 medium to eliminate any contaminating maternal cells. Embryos were cultured in M16 medium. Embryos at 1-cell (18-20 hrs p.c.), 2-cell-(42-44 hrs p.c.), 4-cell-(50-52 hrs p.c.), 8-cell stage (66-72 hrs p.c.), morula and blastocyts (90-92 hrs p.c.) were washed and then individually treated into $5 \mu \mathrm{l}$ drops of acide tyrode to remove the zona pellucida. After washing in two drops of PBS, embryos were treated with warm trypsin for 3 min at $37^{\circ} \mathrm{C}$ to separate the polar bodies from embryo. Embryos were washed into drop of PBS and then placed individually in a PCR tube $(0.2 \mathrm{ml})$ with $5 \mu \mathrm{l}$ PBS. Embryos were lysed by repeatedly ( 3 cycles) freezing on dry ice with methanol and thawing at $90^{\circ} \mathrm{C}$. The entire lysate was used for PCR genotyping.

For isolation of total RNA from preimplantation embryos, cultured embryos were washed with M2 medium and PBS and then collected in an E-cup with RNAase free water. RNA preparation was performed according to QIAGEN® RNAeasy protocol supplied with the 
kit.

\subsubsection{In vitro culture of blastocyst stage embryos}

Embryos were flushed out from the uteri of plugged females at day 3.5 and placed in gelatinized 96-well dishes. Embryos were cultured in ES cell medium without the addition of leukaemia inhibitory factor. The dishes were kept in a humidified incubator at $37^{\circ} \mathrm{C}, 5 \%$ $\mathrm{CO}_{2}$ and embryonic outgrowth was scored daily. Every second day, of fresh medium was added to the wells. DNA was prepared on the fourth day of culture.

\subsubsection{Immunofluorescence staining of mouse preimplantation embryos}

Preimplantation embryos were collected as described (2.12.16.2) and fixed in 4\% paraformaldehyde in PBS for $30 \mathrm{~min}$ at $4^{\circ} \mathrm{C}$. The fixed embryos were washed and transferred to block solution (PBS with $10 \%$ serum and $0.02 \%$ Triton-X) for $30 \mathrm{~min}$. All subsequent incubations were carried out in block solution. The preimplantation embryos were incubated with anti-Fafl antibody (diluted 1/100) overnight at $4^{\circ} \mathrm{C}$, followed by three times (10 min) washing, and then incubate with $3 \mu \mathrm{g} / \mathrm{ml}$ of Cy3-conjugated mouse antigoat IgG for $1 \mathrm{~h}$. Nucleus was counterstained with DAPI for $10 \mathrm{~min}$, rinsed 3 times in PBS for $10 \mathrm{~min}$. Immunostaining of the embryo was examined using a fluorescence-equipped microscope (BX60; Olympus).

\subsubsection{Expression of recombinant proteins in the pET system (Novagen, Darmstadt)}

Plasmid with pET41 constructs were transformed into the host bacterial strain E.coli BL21(DE3). A single bacterial colony containing the vector with the fusion construct was picked from a freshly streacked plate and $50 \mathrm{ml}$ BL culture with kanamycin was inoculated. Bacterial culture was incubated with shaking at $37^{\circ} \mathrm{C}$ until an OD600 of $0.4-1.0$ was reached. A noninduced sample was removed as a control. To the remainder, IPTG from a $100 \mathrm{mM}$ stock was added to a final concentration of $0.4 \mathrm{mM}$ and the incubation step was 
continued for 2-3 hrs. Then, the induced sample was removed and flasks were placed on ice for $5 \mathrm{~min}$. Cells were harvested by centrifugation at $5000 \mathrm{x} \mathrm{g}$ for $5 \mathrm{~min}$ at $4^{\circ} \mathrm{C}$,

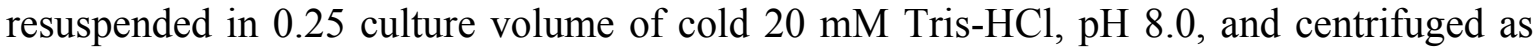
above. Finally, the supernatant was removed and cells were stored as a frozen pellet at $70^{\circ} \mathrm{C}$ or used directly for purification.

\subsubsection{GST Pull-down assay}

GST-fusion proteins were purified from bacterial cell extract using the GST-binding kit (Novagen, Darmstadt). Following reagent were combined in a $1.5 \mathrm{ml}$ microcentrifuge tube on ice. Beads were mixed gently by inverting several times. A sufficient volume of beads was transferred to a clean $1.5 \mathrm{ml}$ microcentrifuge tube. The beads were washed 3 times with $250 \mu \mathrm{l}$ of GST Bind/Wash Buffer (4.3 mM Na $2 \mathrm{HPO}_{4}, 1.47 \mathrm{mM} \mathrm{KH} \mathrm{PO}_{4}, 137 \mathrm{mM}$ $\mathrm{NaCl}, 2.7 \mathrm{mM} \mathrm{KCl}, \mathrm{pH} 7.3$ ) in a microcentrifuge tube and centrifuged at $800 \mathrm{x}$ g for $30 \mathrm{sec}$. The supernatant was removed by aspiration with a micropipette. Steps were repeated and finally, the beads were resuspended to their original volume (i.e., the original beads volume was transferred to microcentrifuge tube) by adding GST Bind/Wash Buffer. $50 \mu \mathrm{l}(100 \mu \mathrm{g})$ GST fusion proteins were added to the GST-beads. To ensure adequate mixing, the reaction tube was rotated at room temperature for $30 \mathrm{~min}$. The tube was centrifuged at 800 $\mathrm{x} g$ for $1 \mathrm{~min}$ and the supernatant discarded. Beads were washed 2 times with lysis buffer B. Then, $100 \mu \mathrm{l}$ of tissue extract $(300-500 \mu \mathrm{g})$ were added to the reaction tube and the mixture was incubated for additional $2 \mathrm{hrs}$ at $4^{\circ} \mathrm{C}$ on a rocking platform. Beads were washed 3 times with $250 \mu \mathrm{l}$ of lysis buffer B for $10 \mathrm{~min}$ at $4^{\circ} \mathrm{C}$. Finally the beads were resuspended in $50 \mu \mathrm{l}$ SDS-PAGE-Loading Buffer, $6 \mu \mathrm{l}$ DTT, and then denaturated and loaded onto a SDS-PAGE minigel. Integrity of the resulting proteins was checked by SDS-PAGE analysis.

\subsubsection{Immunoprecipitation}

Tissues $(200 \mathrm{mg})$ were homogenized in $1 \mathrm{ml}$ lysis buffer and incubated at $4^{\circ} \mathrm{C}$ for $30 \mathrm{~min}$. Lysates were then centrifuged for $30 \mathrm{~min}$ at $4^{\circ} \mathrm{C} 12000 \mathrm{xg}$, the protein concentrations were 
measured and equal amounts of protein were used for immunoprecipitation. $30 \mu 1$ of protein-G-agarose slurry and $5 \mu \mathrm{g}$ of antibody were suspended in $500 \mu \mathrm{l}$ of PBS and an incubated for $1 \mathrm{hr}$ at $4{ }^{\circ} \mathrm{C}$. The beads were washed three times in lysis buffer, then $500 \mu \mathrm{g}$ of lysate protein were added, and the mix was incubated for $3 \mathrm{hrs}$ at $4{ }^{\circ} \mathrm{C}$. The immune complex on the beads was washed three times with washing buffer containing $500 \mathrm{mM}$ $\mathrm{NaCl}$ and $0.1 \%$ Triton $\mathrm{x}-100$ and once with PBS. Beads were boiled in $2 \mathrm{x}$ SDS-PAGE sample buffer, and samples were electrophoresed on 10\% SDS-PAGE gels (Invitrogen).

\subsubsection{Transfection of HeLa cells}

Approximately $4 \times 10^{5}$ Hela cells were plated in a cell chamber (with slide) (Lab-Tek, Wiesbaden) and cultured overnight in $5 \mathrm{ml}$ DMEM medium containing 10\% FCS and penicillin/streptomycin at $37^{\circ} \mathrm{C}$ and $5 \% \mathrm{CO} 2.1 \mu \mathrm{g}$ of DNA (Myc and His fusion) was diluted with the DNA-condensation buffer (buffer EC of the Effection Transfection kit, Qiagen, Hilden) to a total volume of $150 \mu 1,8 \mu \mathrm{l}$ of enhancer was also added to DNA and mixed by vortexing for $1 \mathrm{sec}$. The mixture was incubated at room temperature for $5 \mathrm{~min}$. $25 \mu 1$ of Effectin Transfection Reagent was added to the DNA-Enhancer mixture, mixed by pipetting and incubated for $10 \mathrm{~min}$ at room temperature to allow complex formation. 1 $\mathrm{ml}$ of cell medium was added to the reaction tube, mixed and immediately added into the cell chamber. Cells were incubated for overnight at $37^{\circ} \mathrm{C}, 5 \% \mathrm{CO}_{2}$, to allow for gene expression. The glass slide of the culture chamber was rinsed with PBS and then fixed with methanol for $5 \mathrm{~min}$. One drop of mounting medium with DAPI was dispensed onto the slide. Fluorescent cells were visualised with Olympus BX60 microscope using a 60X neofluor lens, photographed using digital camera and analysed using software 3.0, Soft Imaging System.

\subsubsection{Computer analysis}

For the analysis of the nucleotide sequences, programs like BLAST, BLAST2, MEGABLAST and other programs from National Center for Biotechnology Information (NCBI) were used (www.ncbi.nlm.nih.gov). Information about mouse alleles, phenotypes 
and strains were used from Jackson Laboratory (www.informatics.jax.org). For protein studies ExPASy tools (www.expasy.ch) were used. Mouse genome sequence and other analysis on mouse genes, transcripts and putative proteins were downloaded from Celera discovery system (www.celera.com). 


\section{RESULTS}

\subsection{Expression of mouse Faf1 gene}

\subsubsection{Expression of the Faf1 gene in different tissues of the adult mouse.}

To determine the expression of Fafl gene in different tissues of the adult mouse, $20 \mu \mathrm{g}$ of total RNA from testis, ovary, brain, heart, kidney, liver, lung, thymus, skeletal muscle and spleen was size fractionated in 1\% agarose gel containing formaldehyde and transferred to nitrocellulose membranes. The Northern blot was hybridized with ${ }^{32} \mathrm{P}$-labeled mouse Faf1 cDNA. Only a $2.8-\mathrm{kb}$ transcript of the Fafl gene was detected in the RNA of all studied tissues. Equivalent loading and integrity of the RNA samples were confirmed after hybridization of the blot with human elongation factor 2 (hEF2) cDNA (Fig. 3.1).

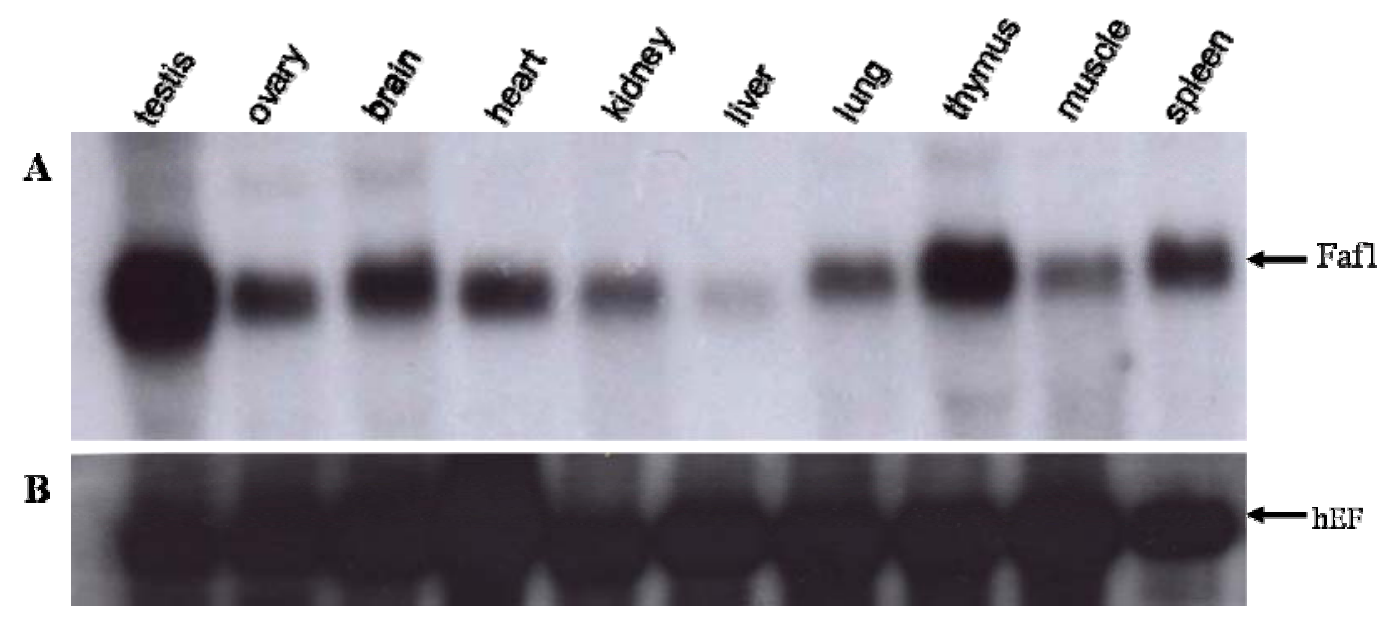

Figure 3.1 Northern blot analysis of Fafl gene expression in adult mouse tissues. Total RNA $(20 \mu \mathrm{g})$ was extracted from different tissues (testis, ovary, brain, heart, kidney, liver, lung, thymus, muscle and spleen) of the adult mouse and subjected to Northern blot hybridization using the Fafl cDNA as a probe (A). Hybridization with the hEF2 cDNA demonstrated the integrity of the loaded RNA (B). 


\subsubsection{Expression of Faf1 protein in mouse tissues.}

To determine the expression pattern of the Faf1 protein, Western blot analysis was performed. Protein was extracted from different tissues of adult mouse, separated on SDS PAGE and transferred onto a nitrocellulose membrane. The polyclonal anti-Faf1 antibody, which was raised against the C-terminal region of protein (sc-1887, Santa Cruz Biotechnology) recognizes a 74-kDa Fafl protein in all studied tissues and a further 49$\mathrm{kDa}$ isoform in testicular extract (Fig. 3.2). The expression level of the 49-kDa isoform was higher than the $74-\mathrm{kDa}$ protein. The membrane was subsequently stripped and probed with anti- $\alpha$ tubulin for monitoring the protein loading.

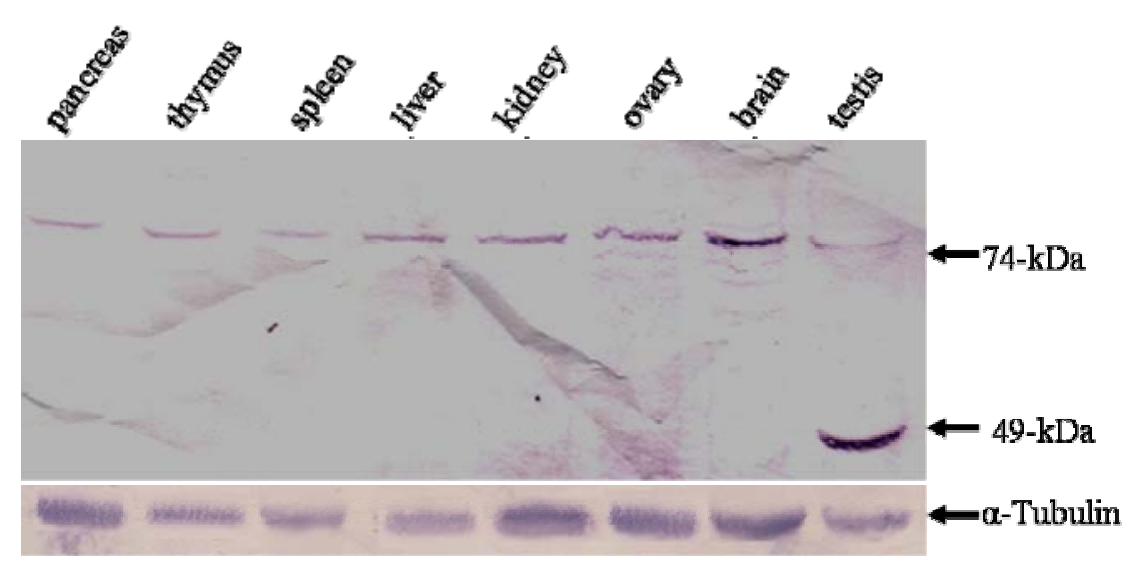

Figure 3.2 Expression of Fafl protein in different mouse tissues. A polyclonal antibody raised against the C-terminus of Fafl protein was used to probe the Western blot with protein extracted from different tissues. The $74-\mathrm{kDa}$ band was found in all tissues, while the $49-\mathrm{kDa}$ isoform was only detected in testis. The membrane was stripped and subsequently probed with an anti- $\alpha$ tubulin monoclonal antibody to monitor the loading. 


\subsubsection{Expression of Faf1 gene during testicular development and in testes of different mutant mice}

To evaluate the expression of the Fafl gene during testicular development, Northern blots with testicular RNAs from 5-, 10-, 15-, 20-, 25- and 60-day-old mice were hybridized with

${ }^{32}$ P-labeled mouse Fafl cDNA. As shown in figure 3.3, a 2.8-kb transcript could be detected during the first three weeks of postnatal development. Thereafter, an increasing level of Fafl expression was observed. This result suggests that the expression of Fafl gene is increased in haploid spermatids.

To examine whether the expression of the Fafl gene is restricted to spermatogenic cells of testis, Northern blot analysis with testicular RNA isolated from $W / W^{\nu}, T f m / Y, I n s l 3, q k / q k$ and olt/olt mutant mice was performed. As shown in figure 3.4, the Fafl transcript was detected at low level in testis of $W / W^{\nu}, T f m / Y$ and at high level in testis of Insl3, $q k / q k$ and olt/olt mice. This result suggests that the Fafl expression is increased in haploid spermatids.

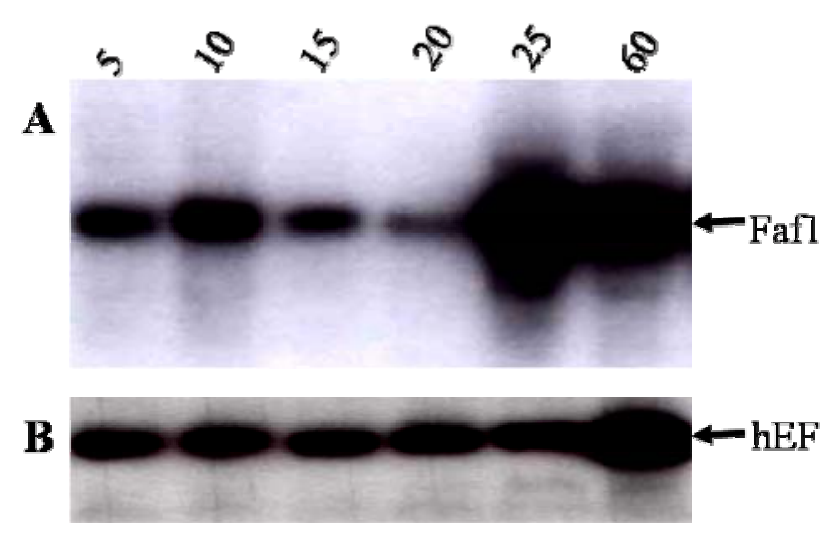

Figure 3.3 Northern blot analysis of Fafl expression during testicular development. (A) Testicular RNA was isolated from 5-, 10-, 15-, 20-, 25- and 60- day-old mice, separated in agarose gel, blotted and hybridized with mouse Fafl cDNA fragment. (B) Rehybridization with human elongation factor to confirm equal amount of RNA loading. 


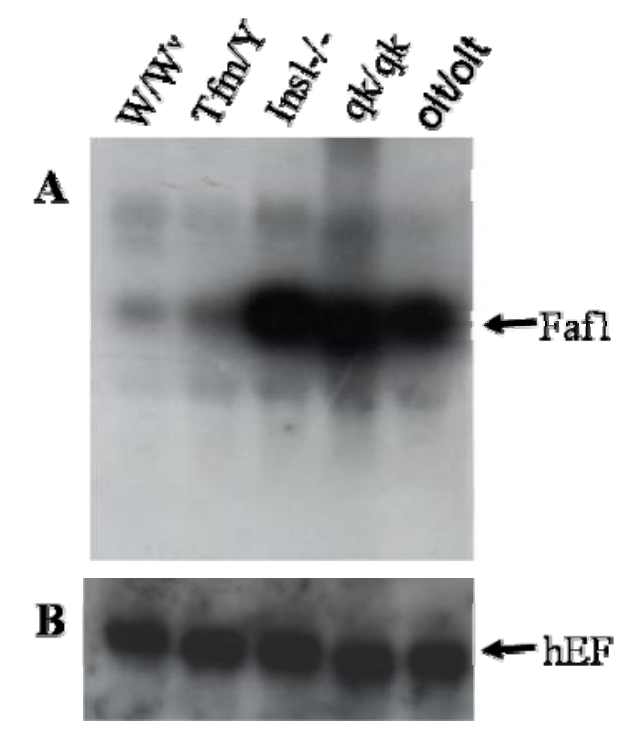

Figure 3.4 Northern blot analysis of Fafl expression in testis of different mutant mice. (A) Total testicular RNA isolated from $W / W^{\nu}, T f m / Y$, Insl3 $3^{--}, q k / q k$, olt/olt mutant mice was hybridized with the mouse Fafl cDNA fragment. (B) Rehybridization of the membrane with human elongation factor2 (hEF2).

\subsubsection{Expression of Faf1 protein during testicular development and in the testis of different mutant mice}

To evaluate the expression of the Fafl during testis development at protein level, total protein extracts from testes of mouse at different developmental stages were analyzed by Western blot. Western blot analysis showed that the $74-\mathrm{kDa}$ isoform is present at equivalent amount throughout testicular development, while the $49-\mathrm{kDa}$ protein is not detectable in mouse testis till postnatal day 21 . The expression of the $49-\mathrm{kDa}$ protein could be first detected at day 25 (Fig. 3.5). Thereafter, we observed an increasing level of the 49$\mathrm{kDa}$ protein.

To verify the specificity of the anti-Fafl polyclonal antibody, competition assay was performed. In this assay, Fafl antibody was incubated with a Fafl oligopeptide which was used to immunize a goat to generate Fafl antibody. After $30 \mathrm{~min}$ of incubation, the solution of competition assay was probed in a Western blot containing protein extracts from testis of wild-type and olt/olt mice. As shown in figure 3.6, the $74-\mathrm{kDa}$ and $49-\mathrm{kDa}$ 
isoforms are abolished in competition assay. This result indicates that the anti-Fafl antibody specifically recognizes the $74-$ and $49-\mathrm{kDa}$ proteins. The observed correlation between the increase of the Fafl transcript and the increase of the 49-kDa isoform in testis of 24- and 30-day-old mice suggests that the $49-\mathrm{kDa}$ isoform is a result of posttranslational modification of the 74-kDa precursor.

The presence of the 49-kDa Fafl was also examined in the testis of mouse mutants, in which spermatogenesis is arrested at different stages. As expected, the 74-kDa protein is found in testes of all mutants. The $49-\mathrm{kDa}$ isoform is present in testes of olt/olt and $q \mathrm{k} / q \mathrm{k}$ mutant mice (in which spermatogenesis is arrested at the spermatid stage), whereas the 49$\mathrm{kDa}$ is not detectable in the testes of $W / W^{v}$ mutant mice (which lack all germ cells), $T \mathrm{fm} / Y$ mice (in which spermatogenesis is arrested at the primary spermatocyte stage) and in cryptorchid testes of Insl3 $3^{-/}$mutant mice (in which spermatogenesis is arrested at the stage of pachytene spermatocytes) (Fig. 3.7). This result indicates that the 49-kDa protein is a spermatid specific isoform.

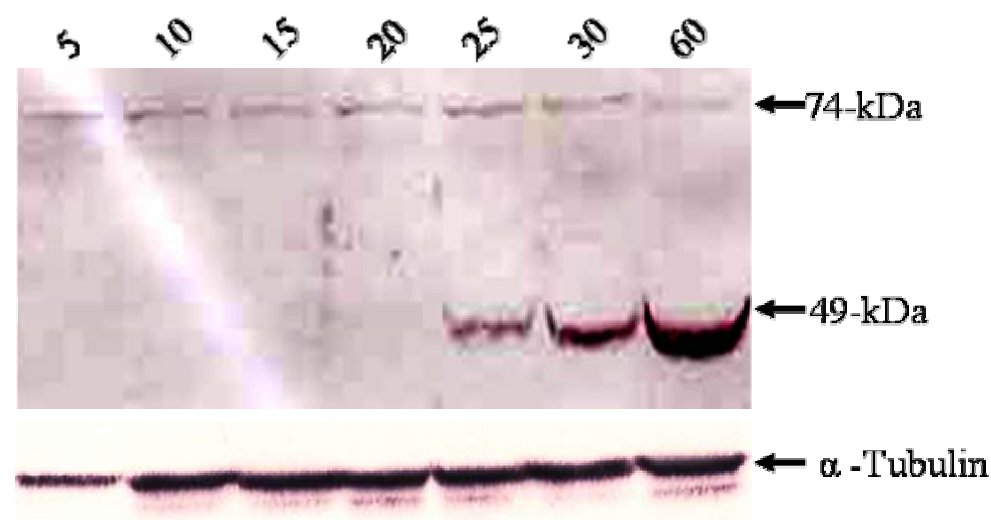

Figure 3.5 Western blot analysis of Faf1 expression during postnatal development of testis. Anti-Faf1 polyclonal antibodies detect a $74-\mathrm{kDa}$ Faf1 protein in testicular lysates from all developmental stages, while 49-kDa Fafl isoform is first detectable in testis of 25-day-old mice. $\alpha$-tubulin in tissue lysates is shown as a control for protein loading. 

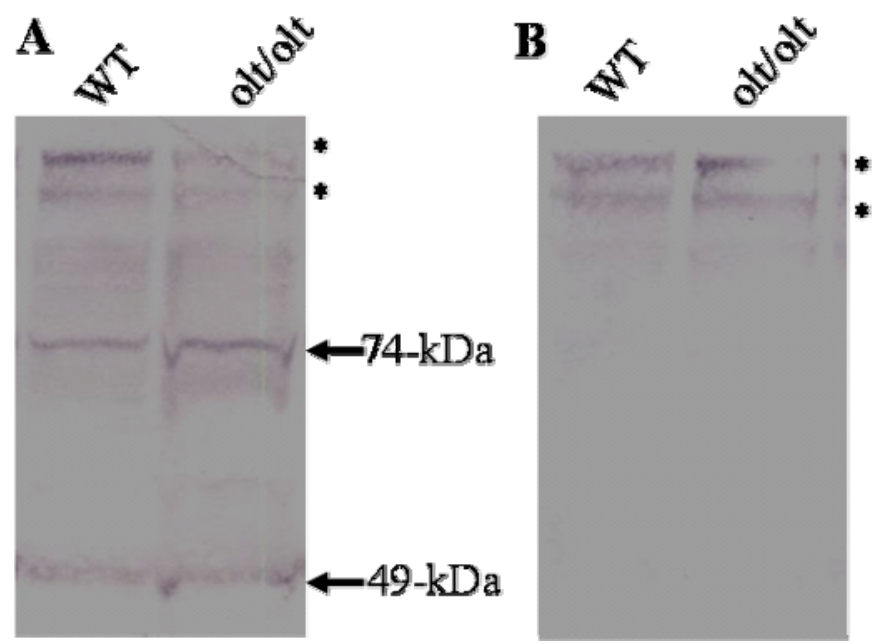

Figure 3.6 Competition assay to verify the specificity of Fafl antibody. (A) Western blot with protein extracts from wild-type and olt/olt testis was probed with Fafl antibody. The Faf1 antibody recognizes the $74-\mathrm{kDa}$ and $49-\mathrm{kDa}$ proteins and high molecular weight proteins (*). (B) In the competition assay, the $74-\mathrm{kDa}$ and $49-\mathrm{kDa}$ Faf1 isoforms were not detected. This result indicates that the anti-Fafl antibody specifically recognizes the 74$\mathrm{kDa}$ and $49-\mathrm{kDa}$ isoforms.

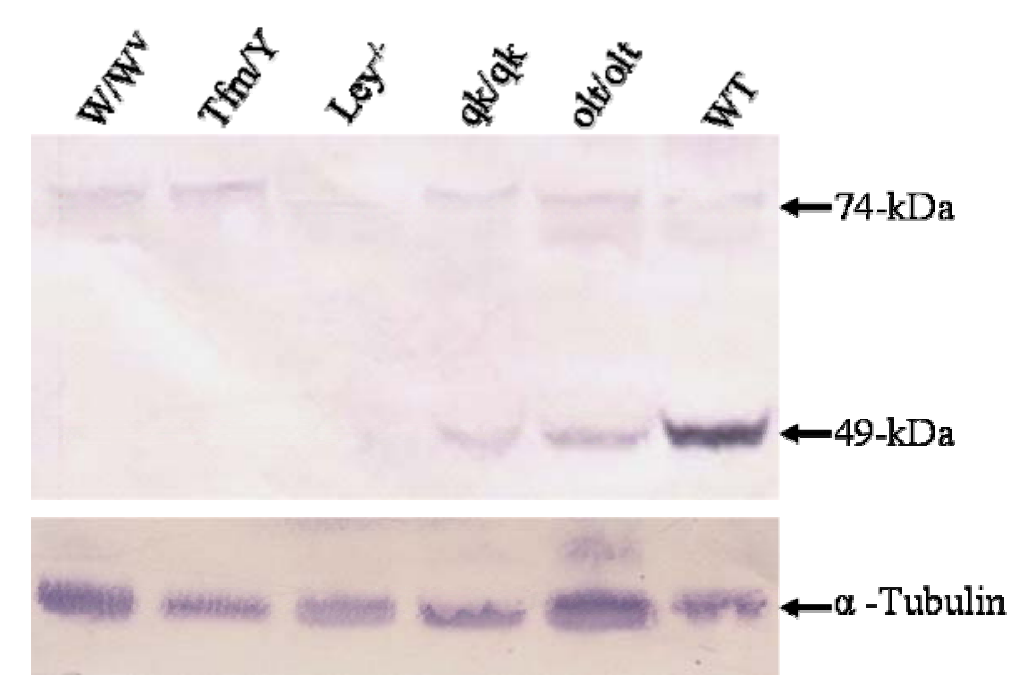

Figure 3.7 Western blot analysis of Fafl expression in testes of different mutant mice. Anti-Fafl antibodies detect 74-kDa protein in testicular lysates from all mutant mice, while the 49-kDa Fafl isoform is present in testes of $q k / q k$ and olt/olt mice. 


\subsubsection{Expression of Faf1 in male germ cells}

\subsubsection{Faf1 expression during male germ cell differentiation}

The cellular localization of Fafl protein in the testis was determined by immunohistochemistry. In testes of wild-type and olt/olt mice, the Faf1 immunoreactivity was mainly detected in the cytoplasm of diploid spermatocytes and haploid spermatids (Fig. 3.8 A, B). In wild-type testis, the highest level of Faf1 protein was observed in haploid spermatids (Fig. $3.8 \mathrm{~A}$ ). In contrast to testes of olt/olt mutant mice, lower level of Faf1 protein was found in round spermatids (Fig. 3.8 B).

Northern blot analysis of Fafl expression revealed that the Fafl is highly expressed in cryptorchid testis of Insl3 $3^{--}$mutant mice in which spermatogenesis is arrested in pachytene spermatocytes (Fig. 3.4). In Western blot, the Fafl antibody recognized only the 74-kDa protein in testicular lysate of Insl3 $3^{--}$mice (Fig. 3.7). Immunohistological staining of testicular sections of $\mathrm{Insl}^{-/-}$mice revealed that the Fafl protein is present at high level in cytoplasm of giant cells, which contain multiple nuclei (Fig.3.8 C, D). 

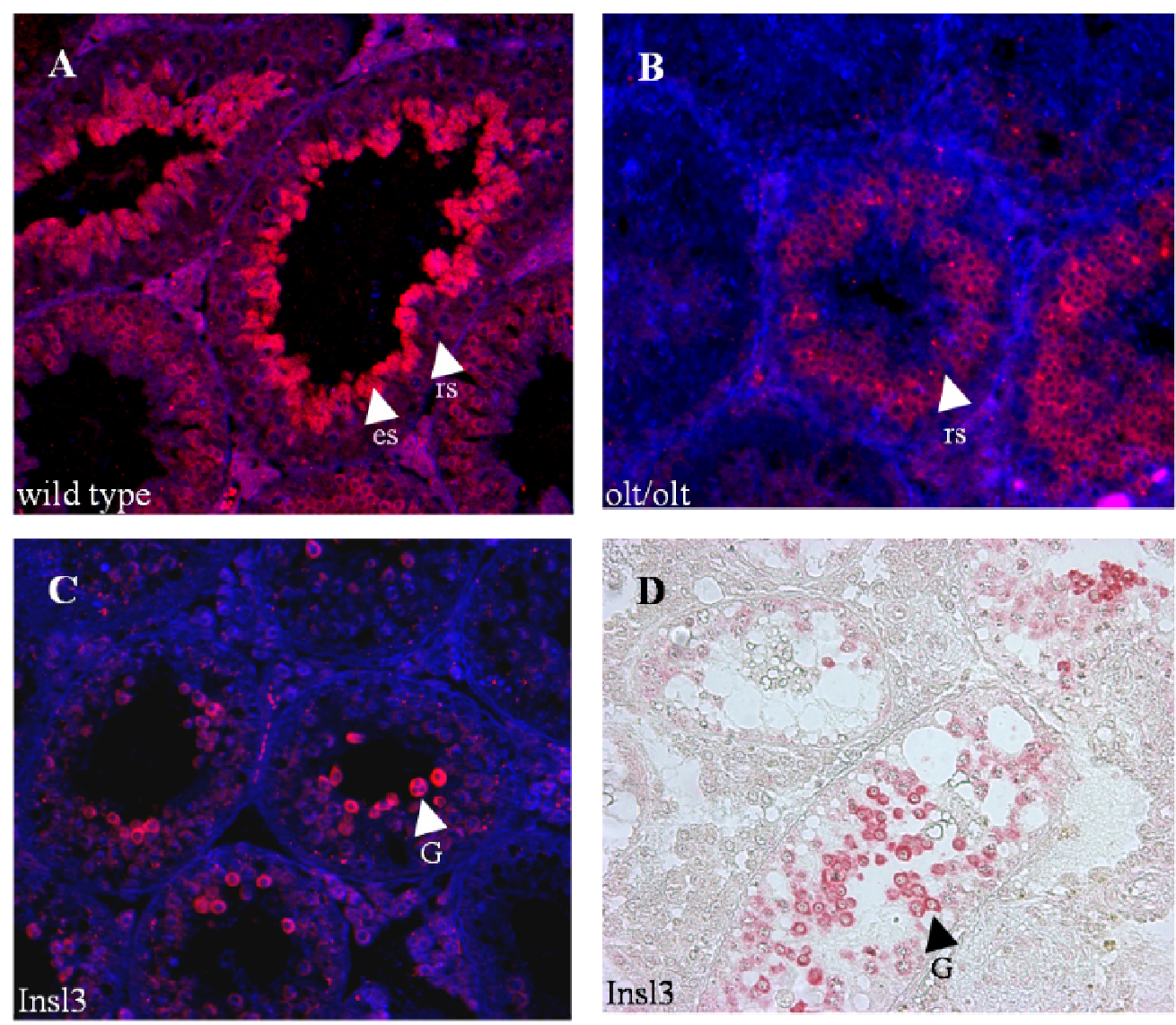

Figure 3.8 Immunohistochemical detection of Faf1 protein in testis of wild-type (A) and olt/olt mutant mice (B). Faf1 protein expression was at low level in diploid spermatocytes and higher in haploid spermatides. In cryptorchid testes of $\operatorname{Insl} 3^{-/}$mice $(\mathrm{C}, \mathrm{D})$ high expression of Fafl protein is restricted to multinuclear giant cells. rs, round spermatid; es, elongated spermatid; G, giant cells. 


\subsubsection{Intracellular distribution pattern of Faf1}

To determine the intracellular localization of Fafl in male germ cells, germ cell suspension of adult mouse testis was prepared, spread on glass slides and stained with anti-Faf1 antibody. The nuclei were counterstained with DAPI. As can be seen in figure 3.9, extensive staining was found in cytoplasm of elongated spermatids and in germ cells containing multiple nuclei. No Fafl expression was found in the mature spermatids. High accumulation of Faf1 in multinuclear germ cells was also observed in cryptorchid testes of Ins13 deficient mice (Fig. 3.8 C, D)
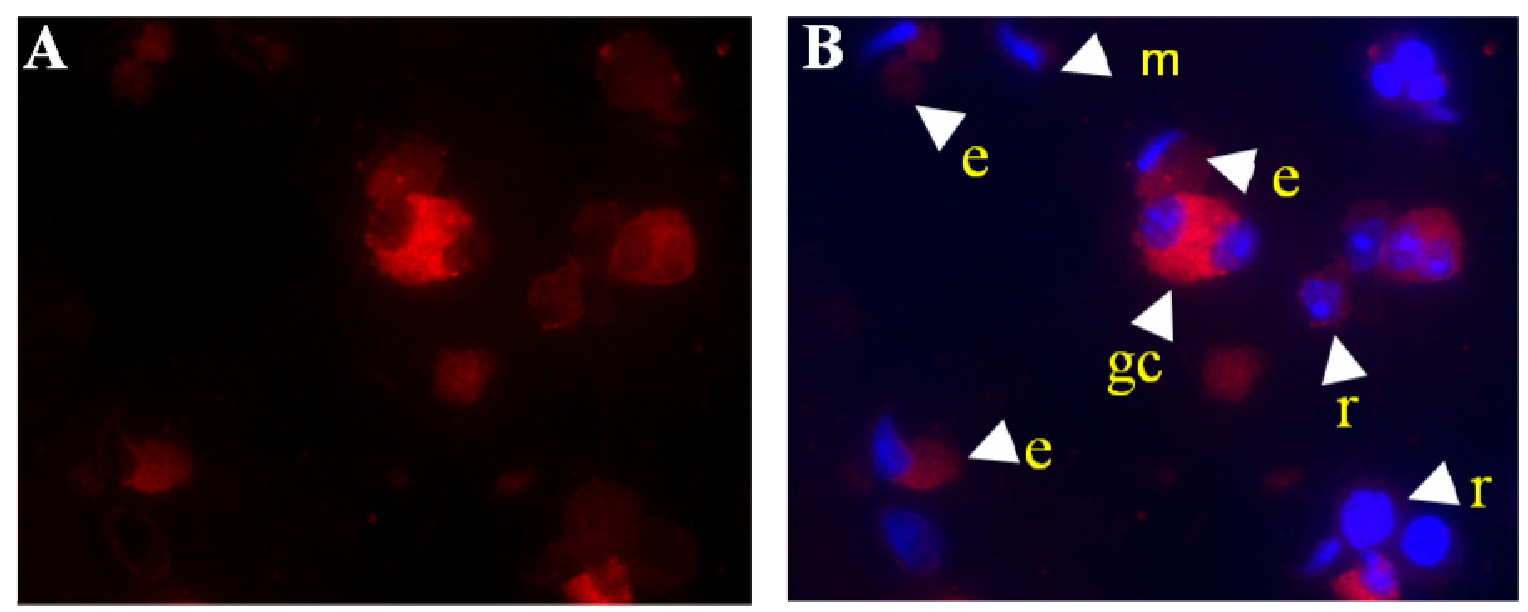

Figure 3.9 Expression pattern of Faf1 protein in male germ cells. In preparations of germ cells suspension, high level of Fafl was found in cytoplasm of elongated spermatids and in multinuclear germ cells. No Fafl protein was detected in mature spermatids. e, elongated spermatids; r, round spermatids; m, mature spermatids; gc, multinuclear germ cells. 


\subsubsection{Expression of Faf1 in ovary}

To determine the expression of Fafl protein in ovary, female mice were injected with 5 IU of human chorionic gonadotropin (HCG; Sigma). Two days later ovaries were isolated and fixed overnight in $4 \%$ paraformaldhyde, dehydrated and embedded in paraffin. Serial sections on glass slides were immunostained with Faf1 antibody.

As shown in figure 3.10 Fafl was only detected in the cytoplasm of oocytes of all follicular stages including primary, secondary and antral follicles. Faf1 was not detectable in ovarian somatic cells.
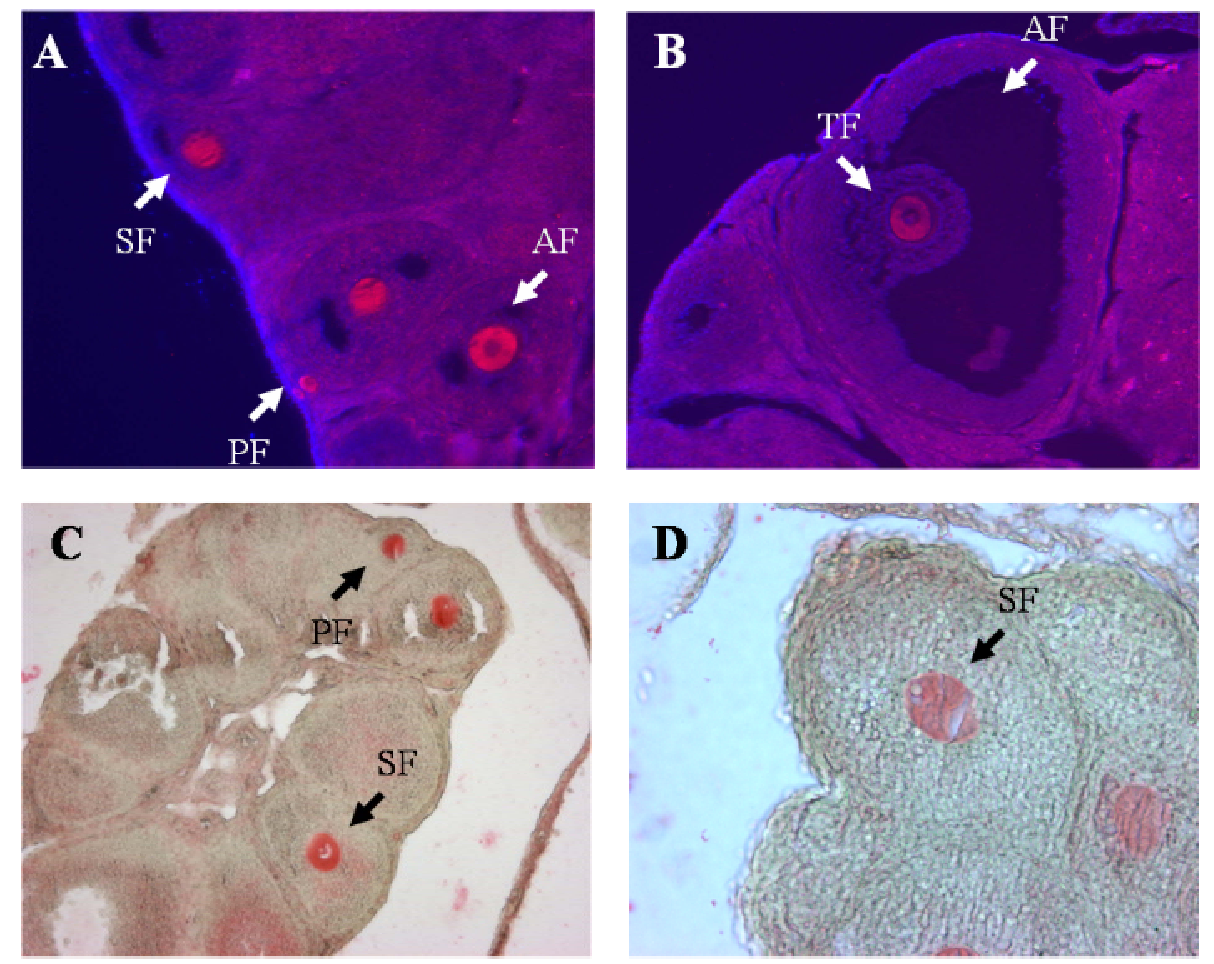

Figure 3.10 Immunohistochemical detection of Fafl protein in mouse ovary. Fafl immunoreactivity was detected in the cytoplasm of oocytes in the primary follicles (PF), secondary follicles (SF) and antral follicles (AF). In (A) and (B), second antibody was antigoat $\mathrm{Cy} 3$ conjugated IgG, while in (C) and (D) it was anti-goat alkaline phosphatase. 


\subsubsection{Expression of the Faf1 protein in oocytes and early cleavage embryos}

Indirect immunofluorescent labeling with the anti-Fafl antisera was used to assess protein expression in oocytes as well as in preimplantation embryos (fertilized oocytes, 2-cell, 4cell, 8-cell stage, morula and blastocyt).

Faf1 protein was localized throughout the cytoplasm in unfertilized oocytes (Fig. $3.11 \mathrm{~A}$ ). This result is consistent with our immunohistochemistry results with ovarian follicles (Fig. 3.10). Faf1 protein assessment after fertilization demonstrates that the maternal protein persists in early zygotes (Fig. 3.11 B) as well as in early cleavage embryos (Fig. 3.11 C, D). Thus, Fafl could theoretically function at any stage of oogenesis and in early embryos.
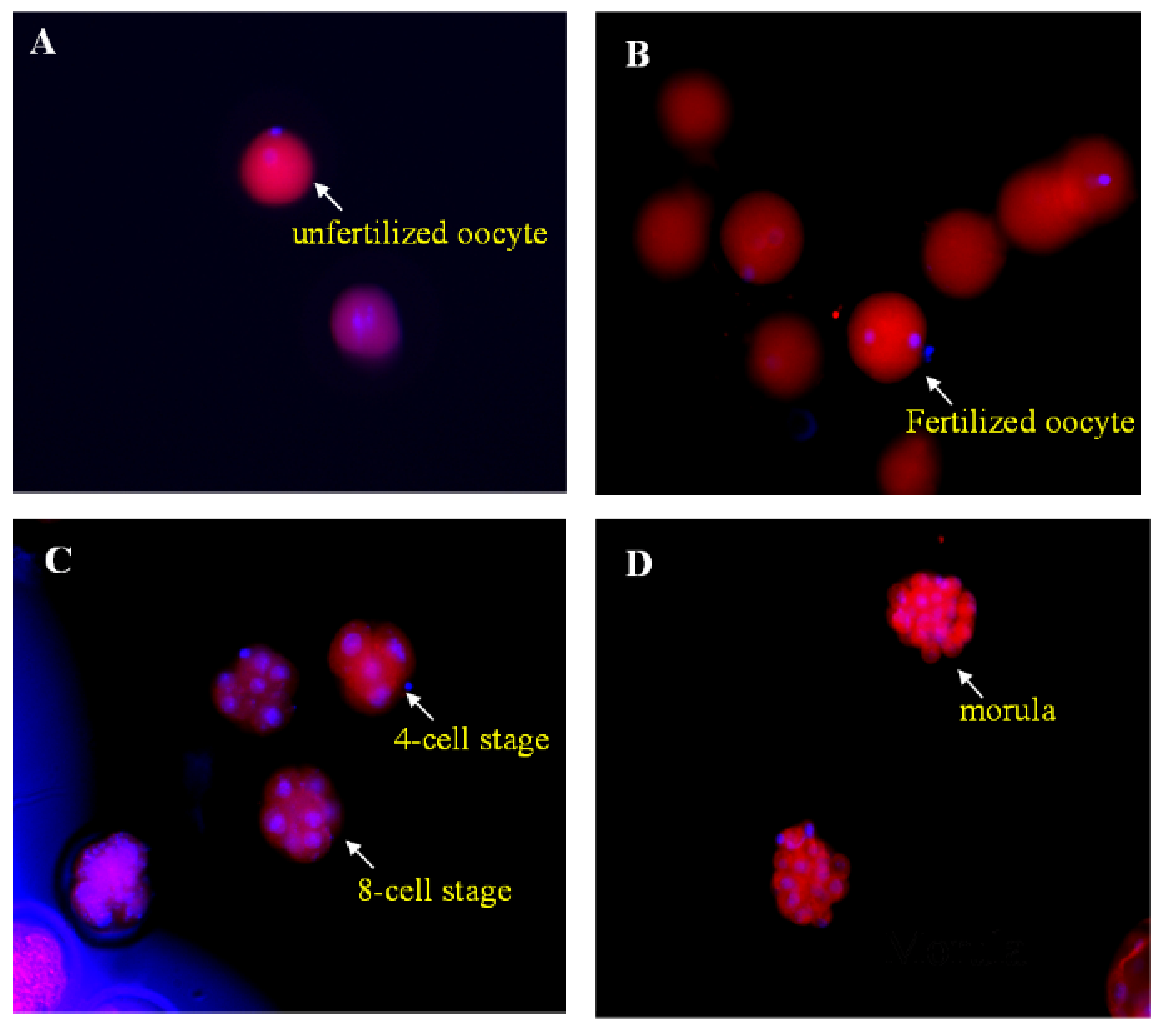

Figure 3.11 Fafl protein was localized using an antibody against Fafl. We studied unfertilized oocytes, fertilized oocytes, 2-cell, 4-cell, 8-cell and morula stage wild-type embryos. Fafl protein assessment after fertilization demonstrates that the protein persists in early zygotes. 


\subsubsection{Expression of the Faf1 in embryonic stem cells}

The high expression of Fafl protein in embryonic cells leads us to examine the expression of the Fafl in different cell lines. Northern blot with RNA from different cell lines was hybridized with Faf1 cDNA. Faf1 gene is highly expressed in embryonic stem cells (ES), murine embryonic teratocarcinoma (F9) and human Teral cell lines (Fig.3.12).

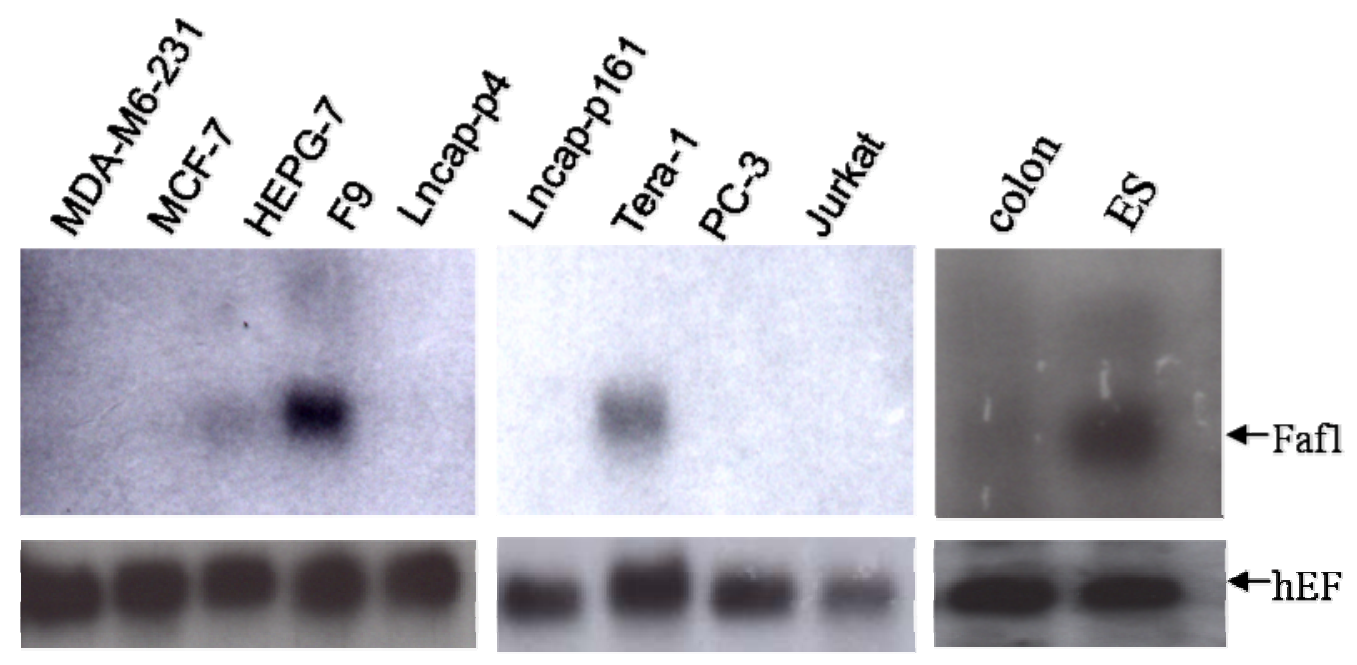

Figure 3.12 Northern blot with RNA from different cell lines reveals that the Fafl gene is highly expressed in embryonic stem cells (ES), murine embryonic teratocarcinoma, (F9), and human Teral cell lines. MDA-M6-231, human breast cancer; MCF-7, human breast cancer; HEPG-7, liver cancer; Lncap-p4, human prostate carcinoma; Lncap-p161, human prostate carcinoma; PC-3, human prostate carcinoma; Jurkat, human T cell leukemia. 


\subsection{Functional analysis of Faf1 gene}

\subsubsection{Establishment of methods for genotyping the gene trap 98-2C line}

Animals of the mouse line 98-2C have been genotyped in the group of Prof. Peter Gruss (Max-Planck-Institute for biophysical Chemistry, Göttingen) by quantitative Southern blot analysis using a LacZ-specific probe. Using this method, we were not able to distinguish between heterozygous and homozygous animals. Therefore, we have designed a breeding program to identify homozygous and heterozygous animals. Animals were first genotyped by PCR using LacZ-specific primers (Fig. 3.13). LacZ-positive mice were intercrossed and offspring were genotyped by PCR. In progeny of these intercrosses, we expected that LacZ-positive animals will be either heterozygous or homozygous for $L a c Z$ gene. To distinguish between heterozygous and homozygous LacZ-mice, LacZ-positive males and females were then backcrossed with-wild type animals. If the LacZ-positive parents would be homozygous, we expected that all offspring in each backcross should be LacZ-positive. Genotyping of progeny from 28 backcrosses revealed the presence of LacZ-positive and negative mice in offspring of all backcrosses. Ratio of the LacZ-positive and LacZnegative offspring in backcross breeding was 1:1 (Table 3.1). This result suggests that all LacZ-positive parents of backcrosses were heterozygous for the trapped gene.

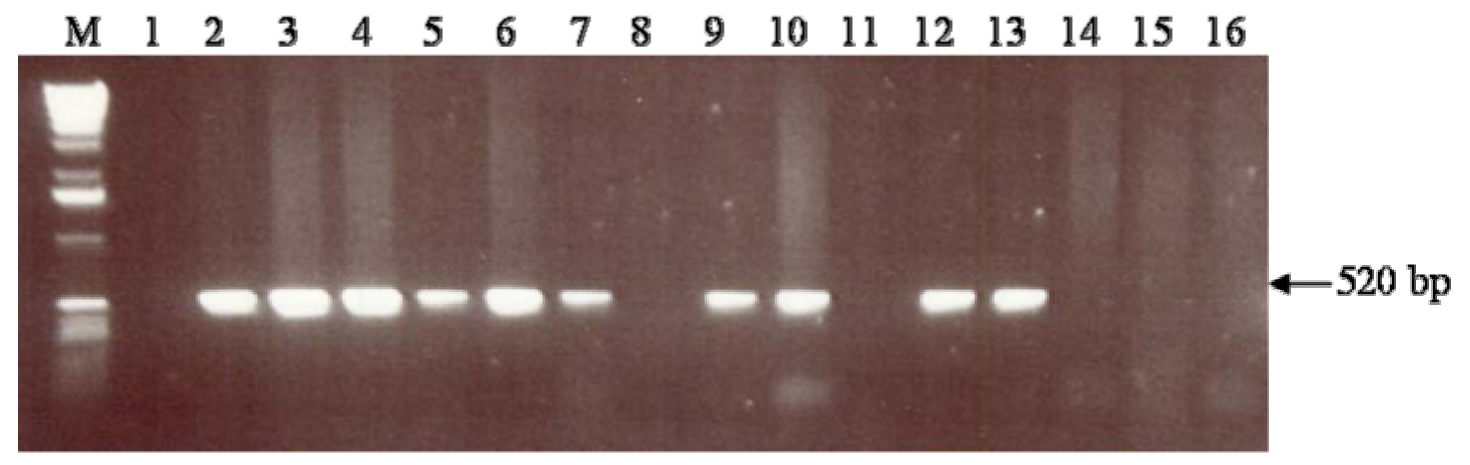

Figure 3.13 Genotyping of offspring in backcrosses between LacZ-positive and wild type mice. LacZ-gene was amplified using the primers LacZF and LacZR. PCR-cycle condition was $94^{\circ} \mathrm{C}$ for $30 \mathrm{sec}, 60^{\circ} \mathrm{C}$ for $30 \mathrm{sec}$ and $72^{\circ} \mathrm{C}$ for $30 \mathrm{sec}$. The PCR products were 
separated on a 1, 5\% agarose gel and stained with ethidium bromide. The length of the amplified LacZ-fragment was 520-bp.

\begin{tabular}{|c|c|c|c|}
\hline \multirow{2}{*}{\multicolumn{2}{|c|}{ Genotype of parent }} & \multicolumn{2}{|c|}{ No of progeny with genotype } \\
\hline & & LacZ-pos. & LacZ-neg. \\
\hline $\begin{array}{l}\hat{0} \text { LacZ- pos. } \\
\hat{0}+/+\end{array}$ & $\begin{array}{l}\text { q }+/+ \\
\text { q LacZ- pos. }\end{array}$ & $\begin{array}{c}130 \\
83\end{array}$ & $\begin{array}{c}133 \\
82\end{array}$ \\
\hline
\end{tabular}

Table 3.1 Genotypes of offspring in backcrosses between LacZ- positive and wild-type animals.

\subsubsection{Identification of the integration site of gene trap vector in Faf1 gene}

The integration site of gene trap vector in the genome of the mouse $98-2 \mathrm{C}$ line was determined by the group of Prof. P.Gruss (Max-Planck-Institute for biophysical Chemistry, Göttingen). This group has cloned and sequenced a genomic fragment containing a gene trap sequence (Fig.3.14 A). Alignment of the genomic sequence in Database revealed the presence of 120-bp sequence of gene trap vector and a sequence of 350-bp located in intron 7 of the Fafl gene (Fig.3.14 B). The 120-bp sequence of the gene trap is located at 3' end of the vector and contains a sequence of intron and splice donor site of Pax-2 gene.

Sequence analysis revealed that the gene trap vector was integrated in the $35-\mathrm{kb}$ long intron 7 of Fafl gene, approximately 23-kb 3'of exon 7 (nucleotide position 108022268108308418 bp of the chromosome 4 genomic counting sequence, GeneBank accession no. NT_039264). We referred the mutated allele in the gene trap 98-2C line as Faf1 ${ }^{G T}$. 


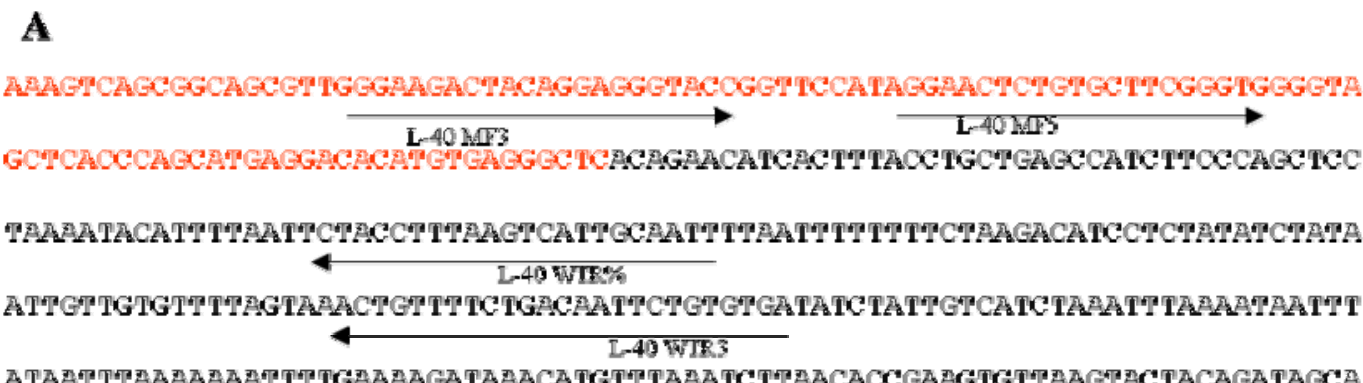

\section{B}

GCAAGAGTCCTATCATATCADCAATATCATTATGTAAATATTTACTATTTTPAAATTAATTGTGATGG

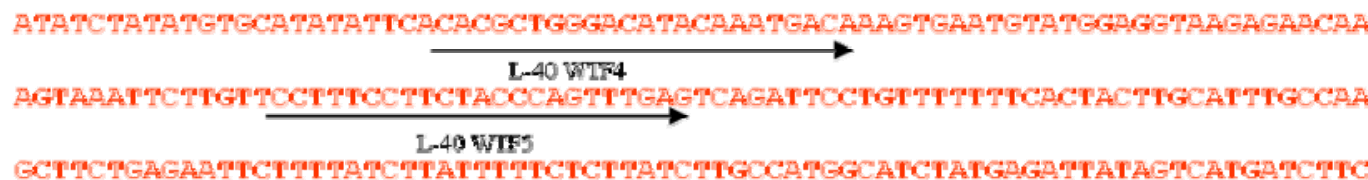

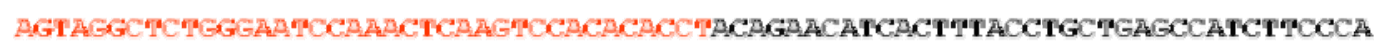

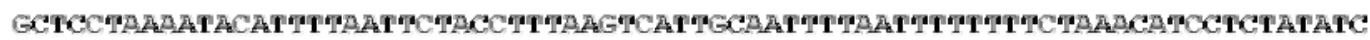

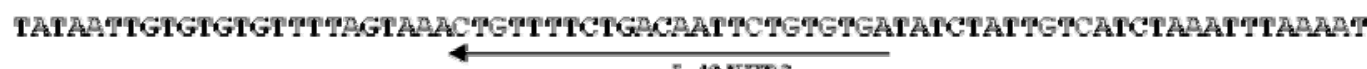

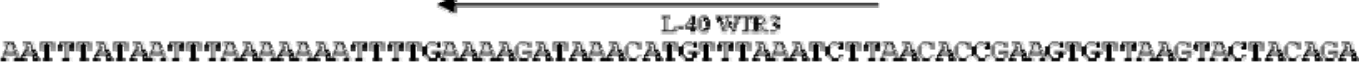

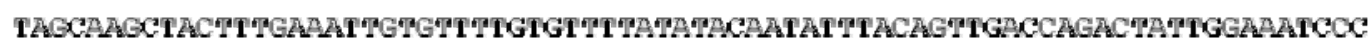
TGTCCAAAAAOCAAATATCTAATATGTAT TAAATATGTAAT TAATCTACAATCTACTATCATAAGCAGAGTTAA

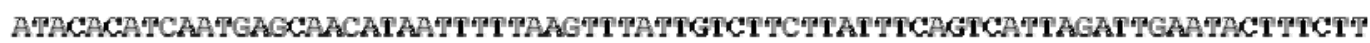

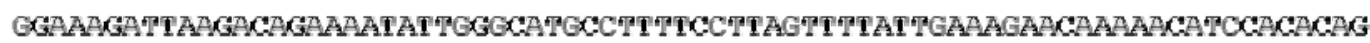
ITCTAAT TAAGGACAAGTGTACICITITICITGAGGIGTAICITIGGTAATCAGCTACIGGATTITACICIXAA ATAGGCTTCAGGGAATITGATCIAATACAGTTOCIAAAGCTATT

Figure 3.14 (A) Sequence of a genomic fragment containing the integration site of gene trap vector in the intron 7 of the Fafl gene. Red letters represent the 3' sequence of gene trap vector. Letter in black are the Fafl flanking sequence. Gene trap specific primers used for genotyping of the Fafl ${ }^{G T}$ allele are indicated. (B) 5' and 3' sequences of Fafl gene, which are flanking the gene trap integration site, are given. Red letters are the 5' sequence, while black letters represent the sequence of 3' sequence of integration site. Locations of the primers, with are used for PCR genotyping of the wild-type and trapped allele, are indicated. 


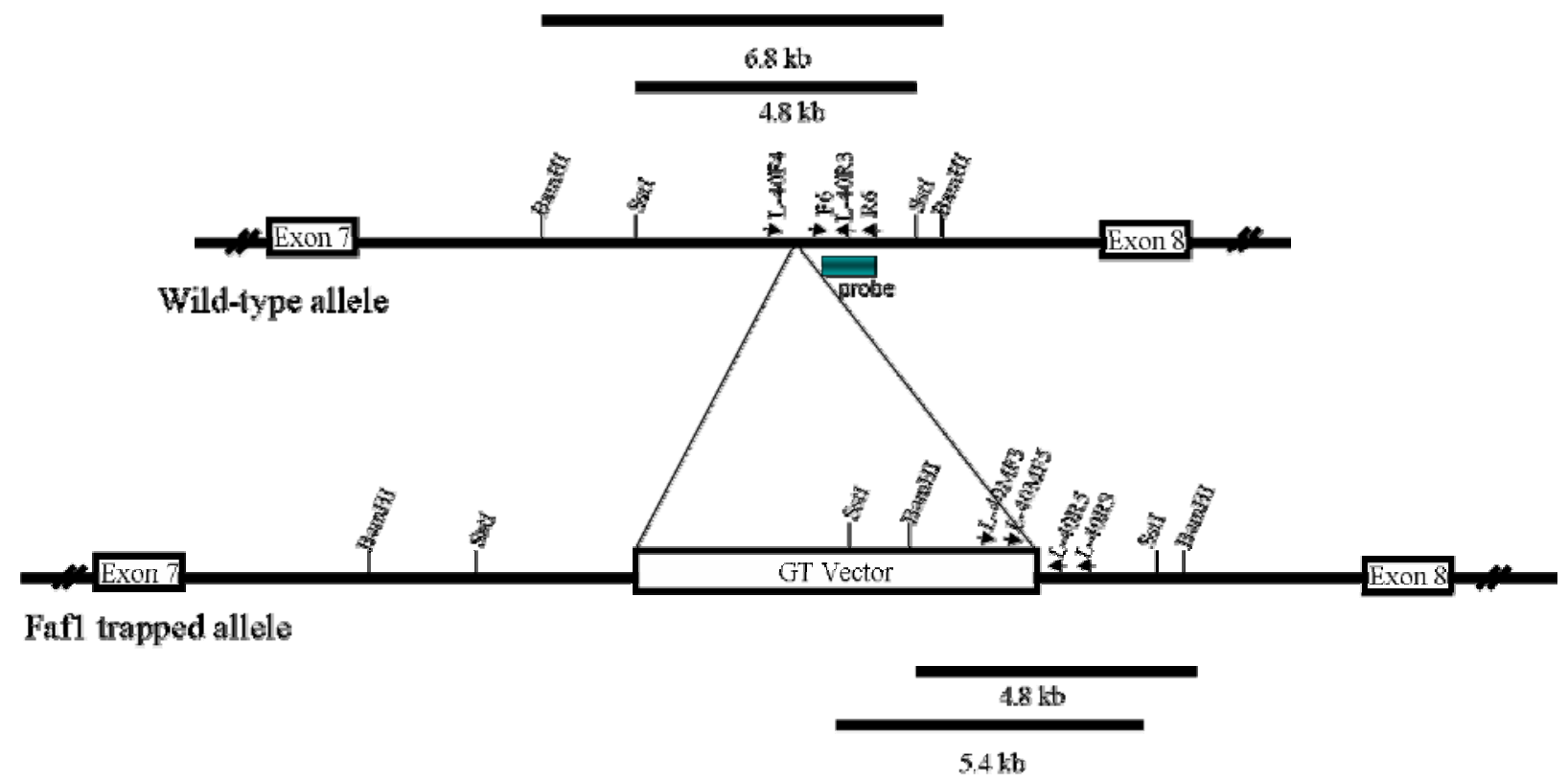

Figure 3.15 Schematic diagrams representing the $\mathrm{Fafl}^{G T}$ and the wild-type allele $\mathrm{Fafl}^{+}$. The positions of the primers L-40 MF3 and L-40 WTR3 used to amplify the trapped allele and primers L-40 WTF4 and L-40 WTR3 used to amplify the wild-type allele are indicated. The primers F6 and R6 were used to amplify the genomic fragment (probe). The lengths of the BamHI- and SstI- wild-type and $\mathrm{Fafl}^{G T}$ genomic fragments, which were hybridized in Southern blot analysis with the probe, are indicated. GT, gene trap.

To establish a Southern blot analysis for genotyping, we have first established a restriction map for the $\mathrm{Fafl}^{+}$and Fafl ${ }^{G T}$ alleles (Fig. 3.15). Using primers F6 and R6, we have amplified a genomic fragment (probe in Fig. 3.15). This 0.6-kb genomic fragment (probe) was radioactively labeled and used to probe a Southern blot with BamHI- and SstIdigested DNA. As expected from restriction map of the Fafl gene, the probe recognizes a 6.8-kb BamHI and a 4.8-kb SstI fragment in DNA of wild-type. In genomic DNA of LacZpositive mice, the probe detected additional $4.8-\mathrm{kb}$ BamHI and 5.4-kb SstI mutant fragments (Fig.3.16 A). We have then used the Southern analysis to genotype 45 LacZpositive mice including animals, which are genotyped as homozygous for trapped allele by using quantitative Southern blot analysis. All 45 mice were found to be heterozygous $\left(F_{a f 1}^{G T /+}\right)$ (Fig. 3.16 B). These results clearly indicated that Faf1 ${ }^{G T / T G}$ homozygotes are lethal. 

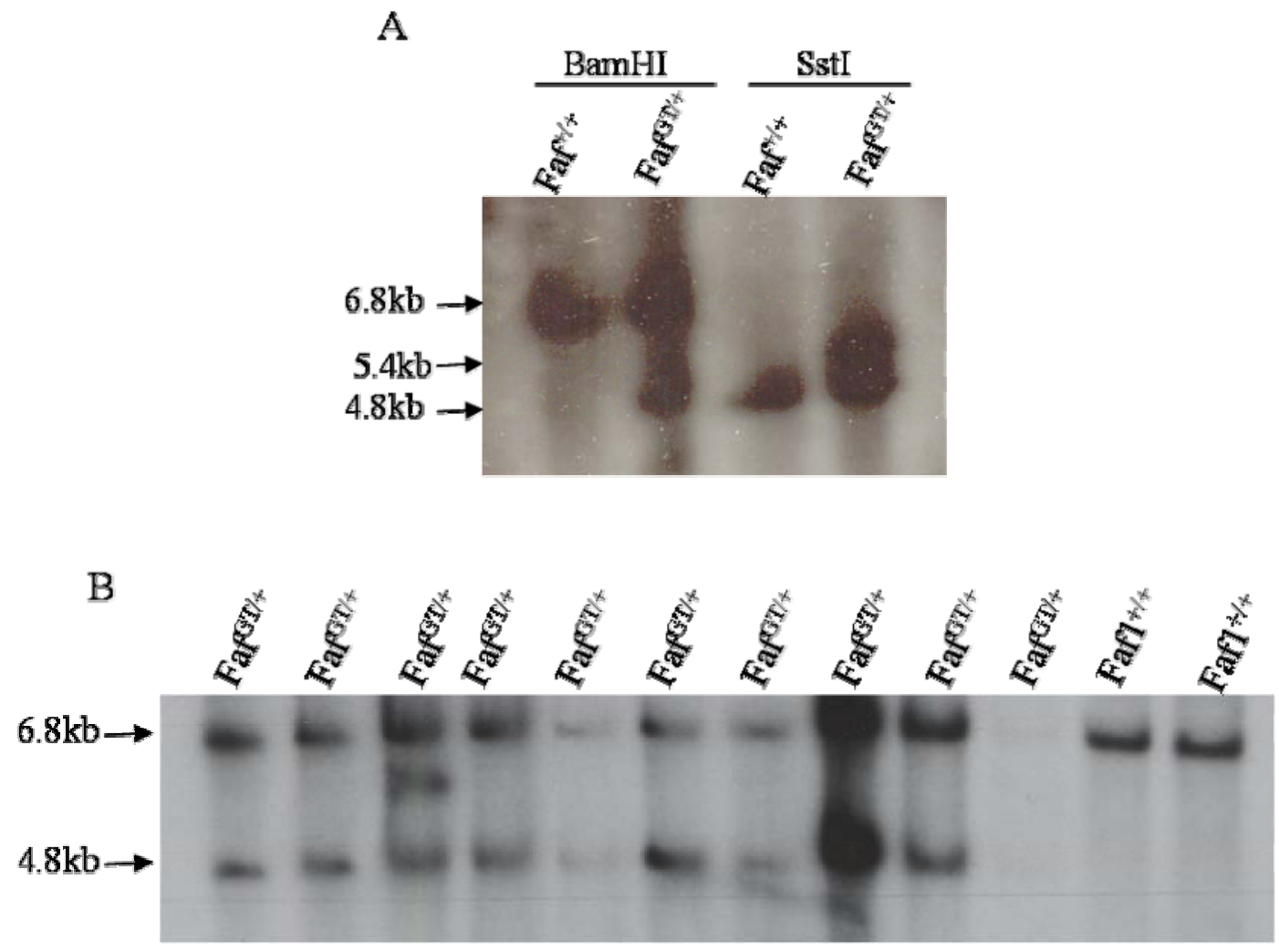

Figure 3.16 Southern blot analyses. (A) Genomic DNA of wild-type and heterozygous mice was digested with BamHI and SstI enzyme, separated on 1\% agarose gel and transferred onto nitrocellulose membrane. The blot was hybridized with radioactively labeled 0.6-kb probe. The probe recognizes a $6.8-\mathrm{kb}$ BamHI and a $4.8-\mathrm{kb}$ SstI wild-type fragment in DNA of wild-type. In genomic DNA of LacZ-positive mice, the probe detected additional 4.8-kb BamHI and 5.4-kb SstI mutant fragments. (B) Genomic DNA from 45 LacZ-positive mice was digested with BamHI and the blots were hybridized with the probe. All analysed LacZ-positive animals were heterozygous for the trapped allele $\left(\right.$ Fafl $\left.^{G T /+}\right)$. 


\subsubsection{Developmental consequences of trapped Faf1 gene}

The Fafl trapped allele was maintained on the 129/Sv X NMRI hybrid and C57 B1/6J inbreed background. Heterozygous mice were mated to obtain homozygous offspring. 291 offspring from 51 litters were analysed by PCR. No homozygous offspring were detected. Similar results were also obtained in the breeding of heterozygous mice on the C57 BL/6J inbreed background (Table 3.2). Because of these results, we have used animals with Faf1 trapped allele on the 129/Sv X NMRI hybrid background for further experiments.

To investigate whether the homozygous $F a f 1^{G T / G T}$ survived until birth, animals of 4 newborn litters obtained from heterozygous intercrosses were genotyped. We could not obtain any homozygous $\mathrm{Fafl}^{G T / G T}$ mice. This result suggests that the homozygotes for the trapped $\mathrm{Fafl}$ allele are embryonic lethal. In crosses between $\mathrm{Fafl}{ }^{\mathrm{GT/+}}$ and $\mathrm{Fafl}{ }^{+/+}$mice in either gender combinations, the ratio of wild-type to heterozygous offspring was close to Mendelian ratio 1:1 (Table 2). All Fafl ${ }^{G T /+}$ females used in the backcrosses were fertile. In contrast, $9 \%$ of $\mathrm{Fafl}^{\mathrm{GT/+}}$ males were infertile.

\begin{tabular}{|c|c|c|c|c|}
\hline \multicolumn{5}{|c|}{ Genotyping analysis of offspring from different breedings } \\
\hline \multirow[b]{2}{*}{ Breeding } & \multicolumn{3}{|c|}{ Genotyping } & \multirow[b]{2}{*}{$\begin{array}{c}\text { Litter } \\
\text { size }\end{array}$} \\
\hline & $\mathrm{Fafl}^{+/+}$ & $\mathrm{Fafl}^{\mathrm{GT} /+}$ & $\mathrm{Faf1}^{\mathrm{GT} / \mathrm{GT}}$ & \\
\hline$\tilde{\mathrm{GTT}} /+\mathrm{x} \quad \mathrm{GT} /+$ (hybrid background) & 93 & 198 & 0 & 6 \\
\hline$\zeta \mathrm{GT} /+\mathrm{x}+\mathrm{GT} /+(\mathrm{C} 57 \mathrm{BL} / 6 \mathrm{~J}$ inbreed background $)$ & 48 & 85 & 0 & 5 \\
\hline$\widehat{\delta}+/+\mathrm{x} \quad \mathrm{GT} /+$ & 29 & 27 & 0 & 7 \\
\hline$\widehat{\jmath} \mathrm{GT} /+\mathrm{x} \quad++/+$ & 34 & 32 & 0 & 7 \\
\hline$\widehat{\partial}+/+\mathrm{x} q+/+(\mathrm{NMRI})$ & 100 & - & - & 10 \\
\hline
\end{tabular}

Table 3.2 Genotypes of offspring from heterozygous and backcross breeding.

To assess the consequences of the Faf1 mutation for embryonic development, embryos were collected from heterozygous intercrosses at different days of postimplantation development (E15.5, E12.5 and E9.5). Genomic DNA was isolated from whole embryos and genotyped by PCR assay using primers L-40WTF4, L-40WTR3 and L-40MF3 (Fig. 3.17 A, B). As shown in table 3.3, no Faf1 ${ }^{G T / G T}$ embryos at E15.5, E12.5 and E9.5 were 
found. Heterozygous intercrosses segregated $\mathrm{Fafl}^{\mathrm{GT/+}}$ and $\mathrm{Fafl}^{+/+}$in a 2:1 ratio indicating that homozygous trapped Fafl allele results in early lethal phenotype. There was no indication of increased uterine resorption at E9.5 and 12.5, suggesting that Faf1 ${ }^{G T / G T}$ embryos do not implant. To investigate whether the Fafl deficient embryos die during preimplantation stages, blastocysts (E3.5) were isolated from heterozygous breedings and cultured for 4 days. Microscopic examination of embryos after four days of culture showed that cells of the inner cells mass (ICM) is able to proliferate in all cultured embryos. DNA was then extracted from cultured embryos and genotyped by PCR analysis. None of these embryos was homozygous for the trapped Fafl allele (data not shown). We have then isolated E0.5 (1-cell stage), E1.5 (2-cell stage), E2.5 (4 cell stage and morula) and E3.5 (blastocyts). To avoid a contamination of genomic DNA of embryos with that of polar bodies, single 1-, 2-, and 4-cell stages were treated with acid tyrode and then trypsin to remove the polar bodies. Single embryos were than genotyped by PCR (Fig. 3.17 A-D). As shown in table 3.3, all blastocyts, morula and 4-cell stages were either $\mathrm{Fafl}^{+/+}$or ${ }^{\mathrm{FaflGT} /+}$, while Faf1 ${ }^{G T / G T}$ embryos were only detected in 1- and 2- cell stage embryos. These results demonstrate that the $\mathrm{Fafl}^{G T / G T}$ embryos die between 2-cell and 4-cell stage. 


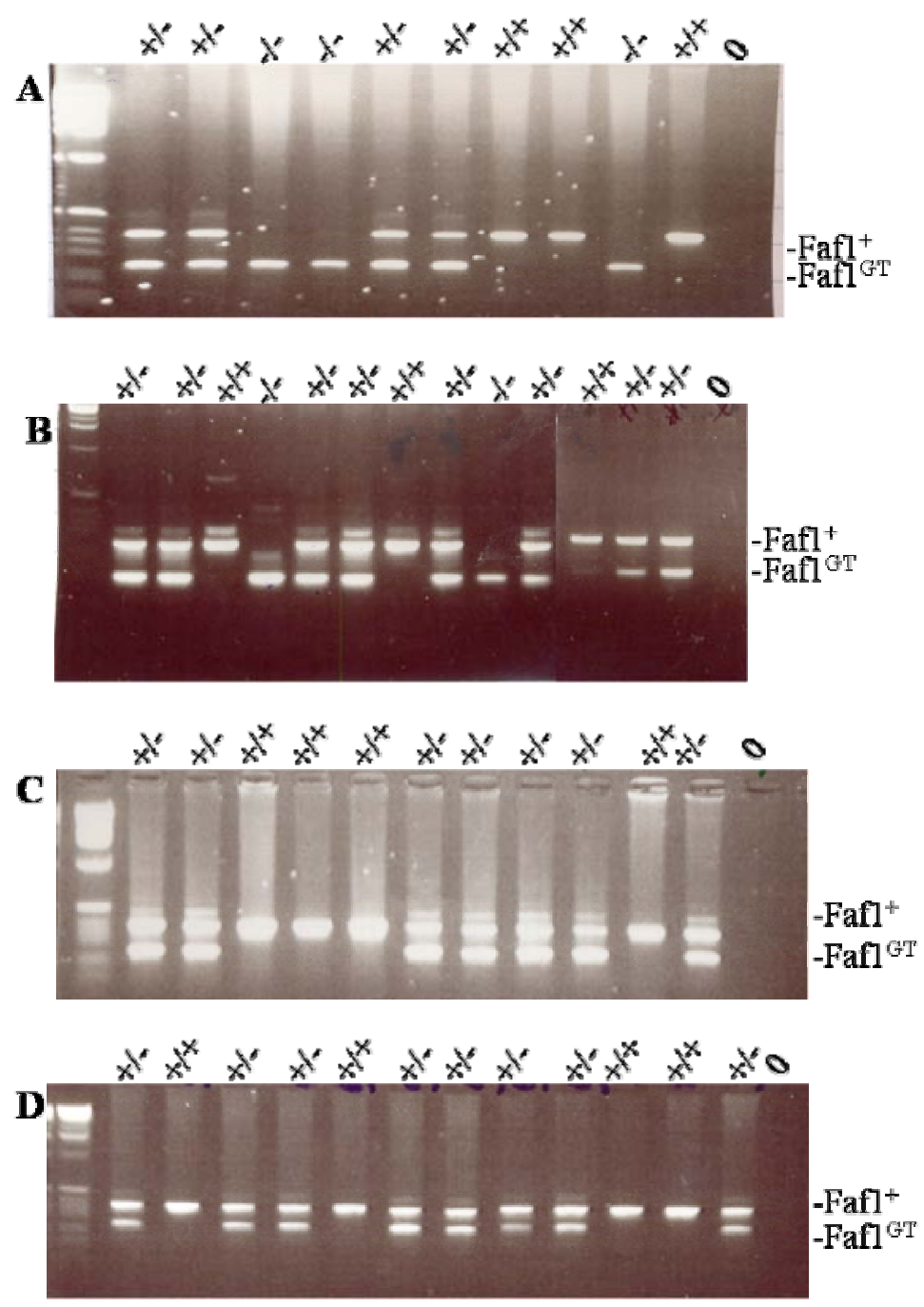

Figure 3.17 Results of the second-round PCR with DNA from E0.5 (A), E1.5 (B), E2.5 (C) and E3.5 (D) embryos which were derived from heterozygous intercrosses. The primers L40WTF4, L-40MF3 and L-40WTR3 (Fig. 3.13 A, B) were used in the first round PCR. Cycle conditions were $94^{\circ} \mathrm{C}$ for $45 \mathrm{sec}, 60^{\circ} \mathrm{C}$ for $45 \mathrm{sec}, 72^{\circ} \mathrm{C} 45 \mathrm{sec}$. The nested primer L40WTF5, L-40MF5 and L-40WTR5 were used in the second round PCR. Cycle conditions were $90^{\circ} \mathrm{C}$ for $30 \mathrm{sec}, 60^{\circ} \mathrm{C}$ for $30 \mathrm{sec}, 72^{\circ} \mathrm{C} 30 \mathrm{sec}$. 


\begin{tabular}{cccc}
\hline & \multicolumn{3}{c}{ No. of progeny with genotyping } \\
\cline { 2 - 4 } Stage & Faf1 $^{\text {+/+ }}$ & Faf1 $^{\text {GI/+ }}$ & Faf1 $^{\text {GT/GT }}$ \\
\hline E15.5 & 7 & 14 & 0 \\
E12.5 & 5 & 13 & 0 \\
E9.5 & 8 & 15 & 0 \\
in vitro culture of E3.5 & 6 & 14 & 0 \\
E3.5 & 5 & 12 & 0 \\
4-cell stage & 9 & 22 & 0 \\
2-cell stage & 6 & 13 & 4 \\
1-cell stage & 10 & 18 & 8 \\
\hline
\end{tabular}

Table 3.3 Genotyping of embryos of different age from heterozygous breedings.

To detect the cause for the embryonic lethality, 2-cell stage embryos obtained from heterozygous intercrosses and wild-type breedings, respectively, were isolated and cultured overnight in M16 medium. Of 75 isolated 2-cell embryos stage from heterozygous breedings, 21 embryos failed to divide after one day of culture and turned necrotic $(28 \%)$, while only 12 of 962 -cell embryos recovered from wild-type breedings failed to proceed beyond the 2-cell stage. After one day of culture, single embryos from heterozygous intercrosses were genotyped after removing the polar bodies. 4 embryos were wild-type and 7 were heterozygous. In all necrotic embryos, the polar bodies could not be distinguished from embryonic cells; therefore, the whole necrotic embryo was genotyped. Genotyping of the 13 necrotic embryos recovered after one day in culture revealed that 12 embryos were heterozygotes and 1 was of unknown genotype. The failure to detect $\mathrm{Fafl}^{\mathrm{GT} / \mathrm{GT}}$ and $\mathrm{Fafl}^{+/+}$in necrotic embryos may be due to contamination of the embryonic genome with that of polar bodies. Increased number of embryos (28\%) from heterozygous intercrosses, which failed to proceed beyond the 2-cell stage in vitro, as compared to $13 \%$ in wild-type breeding suggests that the Fafl is essential for cell viability or cell proliferation. To address the question, whether the lethality of the $F a f 1^{G T / G T}$ is due to apoptotic cell death, E1.5 embryos were recovered from heterozygous and wild-type 
crosses and stained by TUNEL assay. No embryo with intensely labeled nuclei, which is indicative of apoptotic cell death, was observed. One embryo which was isolated from wild-type breeding was arrested at one-cell stage and its nucleus was intensely stained (Fig. $3.19 \mathrm{C})$. This result suggests that the developmental arrest of $\mathrm{Fafl}^{G T / G T}$ is not due to apoptotic cell death.
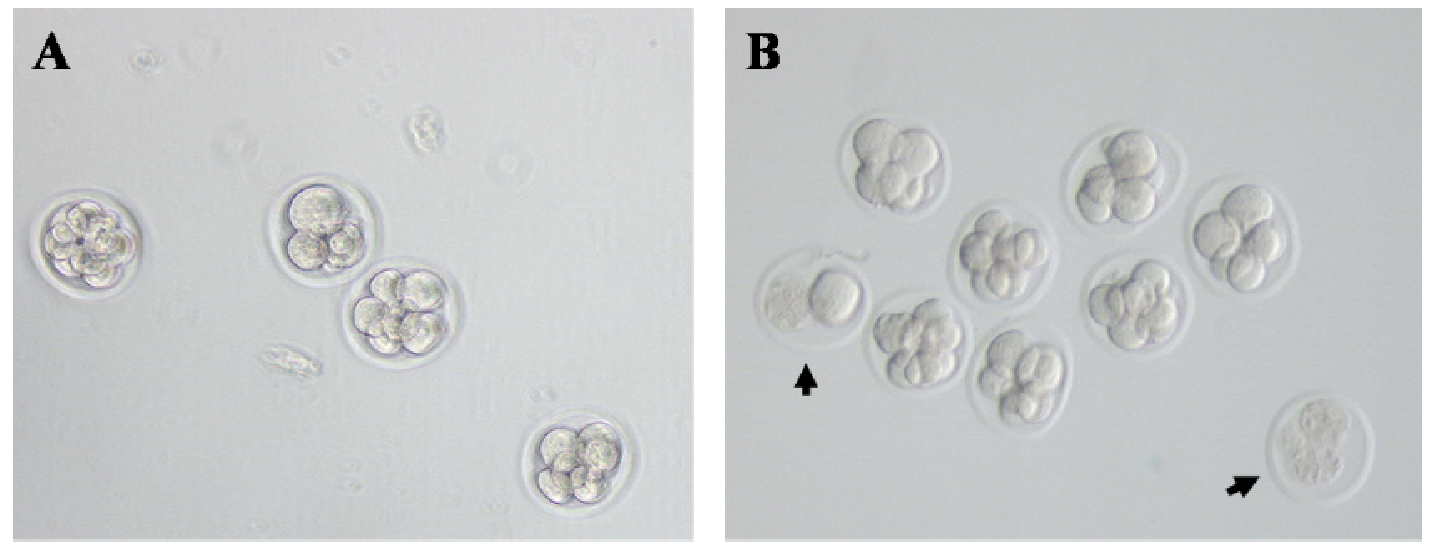

Figure 3.18 E1.5 embryos collected from plugged females of wild-type (A) and heterozygous (B) intercrosses were cultured in M16 medium with $5 \% \mathrm{CO}_{2}$ at $37^{\circ} \mathrm{C}$. Pictures were taken $36 \mathrm{~h}$ after culture. An increased number of necrotic embryos were observed from in vitro cultured of embryos recovered from heterozygous intercrosses. Arrows indicate necrotic embryos. 

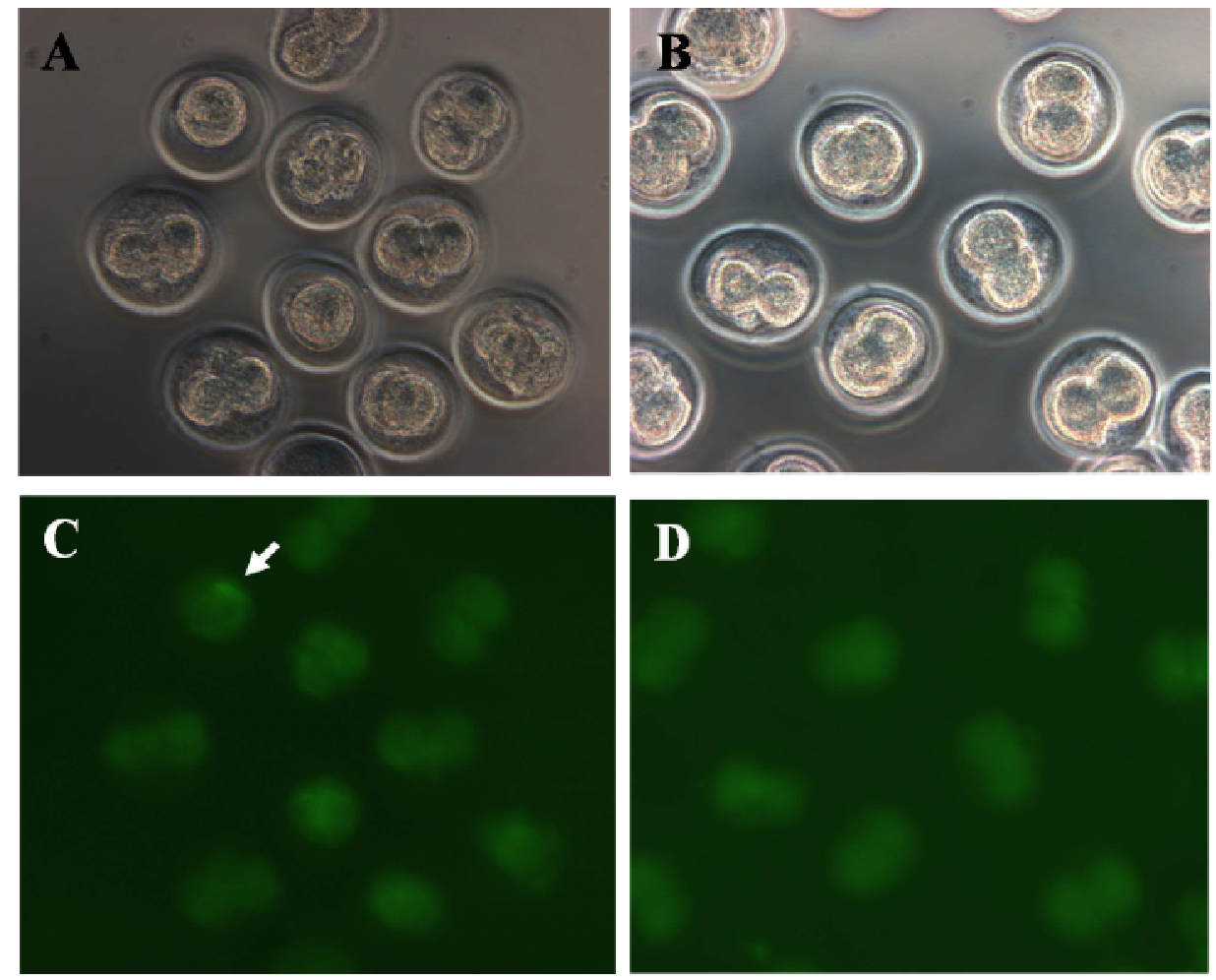

Figure 3.19 TUNEL staining of E1.5 embryos recovered from wild-type and heterozygous breedings. Phase contrast pictures of E1.5 derived from wild-type and heterozygous breedings are shown. (C) Nucleus of one wild-type embryo at 1-cell stage showed strong TUNEL staining (arrow). In contrast, all 2-cell stage embryos from wild-type (A) and heterozygous (B) intercrosses are unstained.

\subsubsection{Expression of embryonic Faf1 gene during preimplantation}

Immunohistochemical staining of ovary and early embryonic stages revealed that Faf1 is highly expressed in oocytes of all follicle stages and in all preimplantation stages. This result demonstrates that the Fafl protein in oocytes is present as maternal storage and may be transferred to and used by early embryonic cells during the first rounds of division. The persistence of maternally Faf1 protein in the embryos could explain the normal development of $\mathrm{Fafl}^{G T / G T}$ to the 2-cell stage despite mutation of the Fafl gene in the embryos. To determine the preimplantation expression profile of Fafl, RT-PCR on total RNA prepared from 1-cell, 2-cell, 4-cell, morula and blastocyt stages was performed. To control for the relative abundance of Fafl transcript, we included RT-PCR analysis for the 
ubiquitously expressed Gapdh gene. Whereas the Gapdh is expressed throughout preimplantation stages, Fafl transcripts are not detectable in 1- and 2-cell stages. The expression of embryonic Fafl starts at 4-cell stage and is increased thereafter (Fig. 3.20).

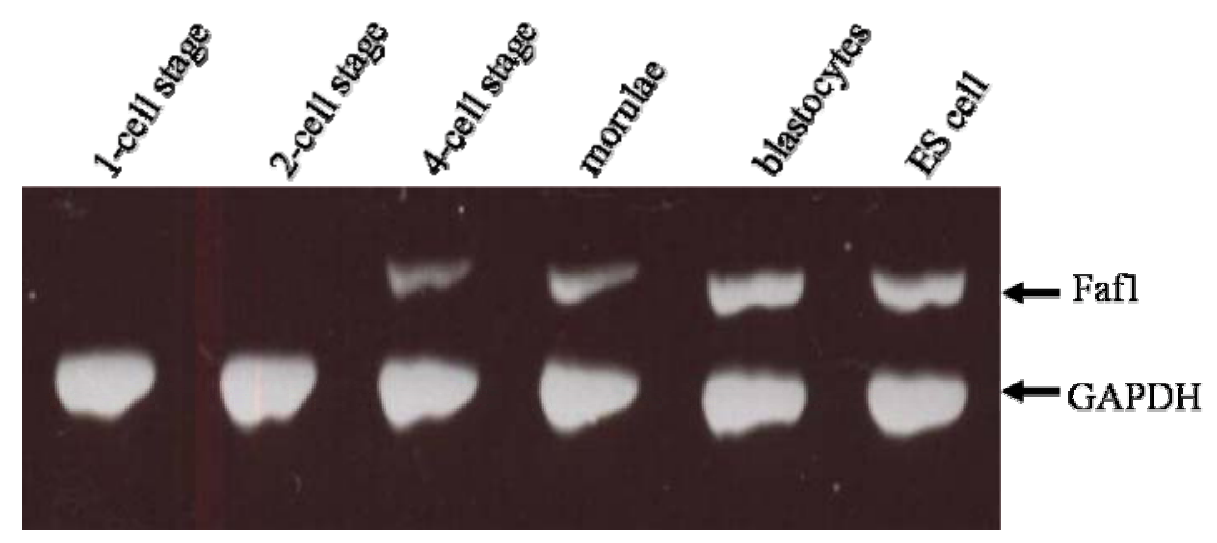

Figure 3.20 embryonic Fafl expressions in preimplantation stages. RT-PCR was used to detect Fafl and Gapdh transcripts in total RNA preparations from wild-type 1-, 2-, 4-cell stage, morula, blastocysts and ES cells.

\subsubsection{Reproductive functions of Faf1 in male animals}

\subsubsection{Fertility test experiments}

In breedings of $\mathrm{Fafl}^{G T /+}$ males with wild-type females, two infertile males were found. We performed hematoxylin-eosin staining of testicular sections from infertile heterozygotes. Histological analysis revealed complete depletion of meiotic and postmeiotic germ cells in testes of both infertile males. By contrast, the full component of spermatogenic cells, including spermatogonia, spermatocytes and spermatids was detected in fertile heterozygous males (Fig. 3.21). The germ cell degradation in testis of some heterozygous animals lead us to determine whether apoptotic cell death in infertile testes of $\mathrm{Fafl}^{G T /+}$ mice is responsible for impaired spermatogenesis. Testicular sections from fertile and 
infertile $\mathrm{Fafl}^{G T /+}$ mice were stained with TUNEL assay. For control, we stained sections from wild-type and from $\mathrm{Apg}^{-/-}$testes, which show high number of apoptotic cells. As shown in figure 3.22 , the number of apoptotic cells in testes of fertile and infertile Faf1 ${ }^{G T /+}$ mice was not significantly different from that observed in sections of wild-type testis.
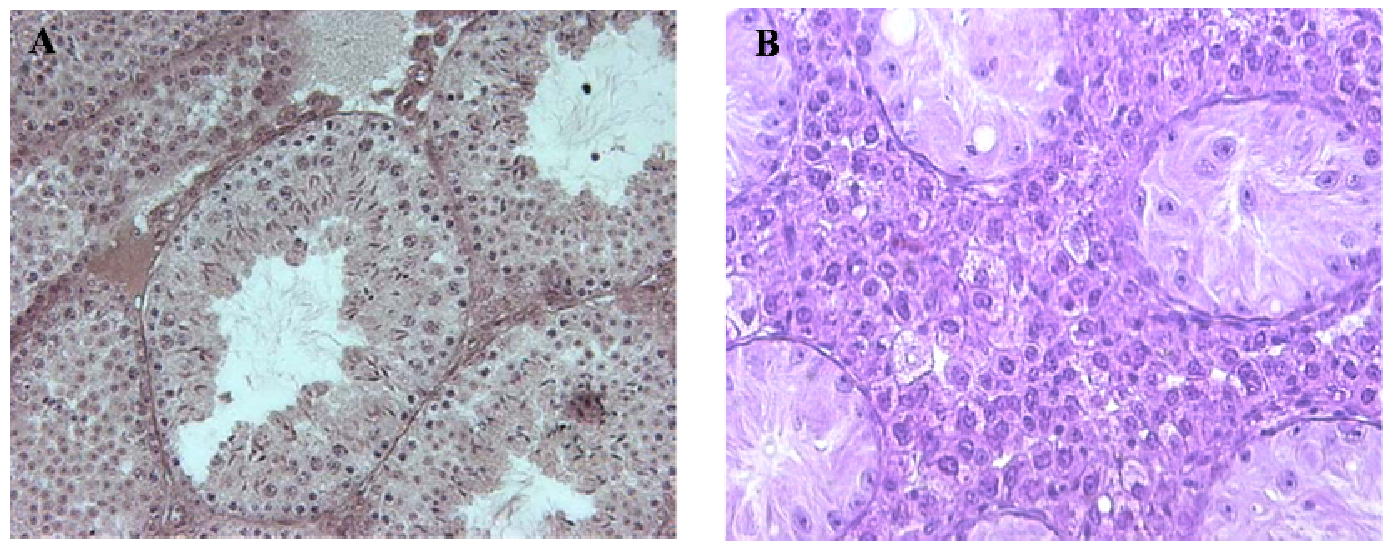

Figure 3.21 Hematoxylin-eosin staining of testicular sections from wild-type (A) and infertile $\mathrm{Fafl}^{G T /+}$ mice (B). Histological analysis revealed complete depletion of meiotic and postmeiotic germ cells in testes of infertile $\mathrm{Fafl}^{\mathrm{GT/+}}$ males. 

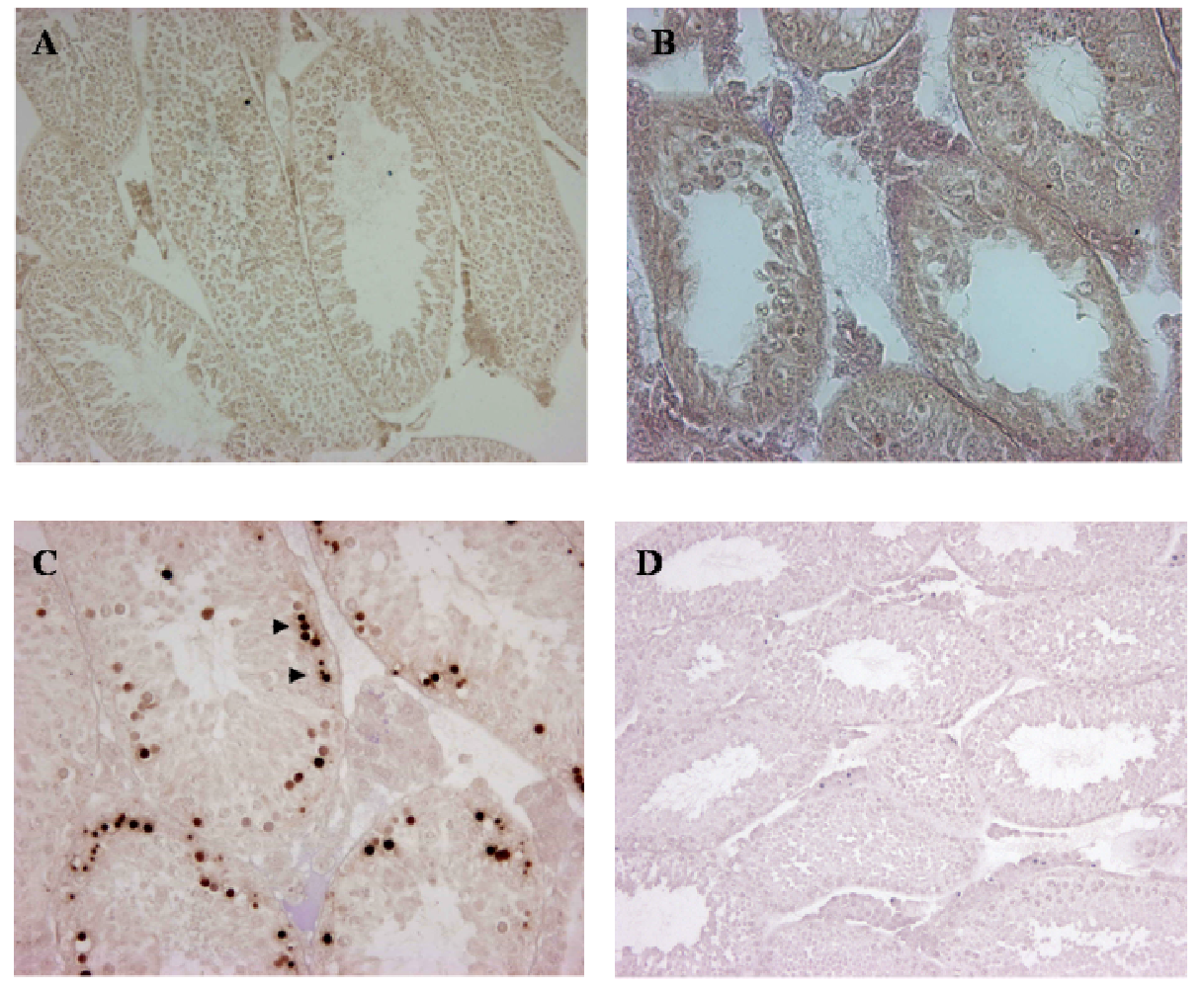

Figure 3.22 TUNEL staining of testicular sections from fertile $F_{a f 1}{ }^{G T /+}$ mice (A) and infertile $\mathrm{Fafl}^{G T /+}$ mice (B). For positive control, testicular sections of $\mathrm{Apg}^{-/-}$mice (C) and wild-type mice were used (D). No significant increase of TUNEL- positive cells was detected in fertile and infertile $F$ af $1^{G T /+}$ testes as compared to wild-type testes.

\subsubsection{Expression analysis of the Faf1 trapped allele}

Gene trap vector, which is integrated in intron 7 of Fafl gene, contains the splicing acceptor site of mouse engrailed-2 gene, followed with IRES sequence and LacZ gene. Therefore, we expected that the mRNA fusion transcript from the Fafl trapped gene contains the sequence of exon 1 to exon 7 of Fafl and the LacZ gene (Fig. 3.23). Furthermore, the vector contains the neomycin gene under the control of the $\beta$-actin promoter. The absence of the poly-A signal in the neomycin gene and presence of the splice donor site of Pax2 gene at 3' end lead to expect that the Fafl trapped allele ubiquitously transcribe a second fusion mRNA. This fusion transcript should contain the sequence of the $\beta$-actin and the 3' located sequence of Fafl (Fig.3.23). 


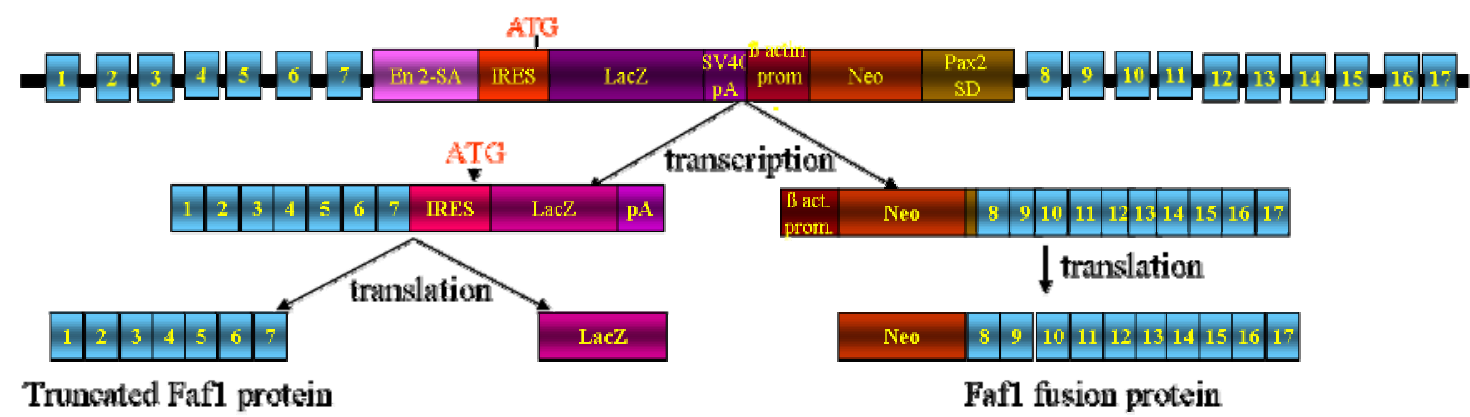

Figure 3.23 Schematic diagrams represent which the Fafl trapped allele, the expected fusion transcripts and proteins. En2-SA, mouse engrailed-2 splice acceptor site; SD, mouse Pax-2 splice donor site; IRES, internal ribosomal entry site from the encephalomyocarditis virus; ATG, translation initiation codon; LacZ, $\beta$-galactosidase ( $\beta g a l)$ expressing gene and neo, neomycin phosphotransferase gene under control of the human $\beta$-actin promoter; $\mathrm{pA}$, SV40 polyadenylation signal.

To evaluate whether Fafl transcripts are affected by integration of the gene trap vector, Northern blot analysis was performed with testicular RNA from wild-type, fertile and infertile $\mathrm{Fafl}^{G T /+}$ mice. By using cDNA probes localized 5' and 3' of the integration site, two transcripts of 2.8-kb (wild-type) and of 3.5-kb (trapped transcript) were detected in testis of $\mathrm{Fafl}^{\mathrm{GT} /+}$ mice (Fig. $3.25 \mathrm{~A}, \mathrm{~B}$ ). Hybridization of the $3.5-\mathrm{kb}$ trapped transcript with the 5' and 3' cDNA probes suggests a partial integration of the gene trap vector in the 3.5$\mathrm{kb}$ transcript. The level of the $3.5-\mathrm{kb}$ trapped transcript is lower than that of the $2.8-\mathrm{kb}$ $\mathrm{Fafl}^{+/+}$transcript in testis of fertile $\mathrm{Fafl}^{\mathrm{GT/+}}$ mice (Fig. $3.25 \mathrm{~A}, \mathrm{~B}$ ). In contrast, the level of Faf1 ${ }^{G T}$ transcript was prominent in testis of infertile $F a f 1^{G T /+}$ animals. Rehybridization of the Northern blot with the LacZ probe revealed a weak hybridization of the 3.5-kb fusion transcript with the LacZ probe. This result suggests that a short sequence of the LacZ gene is integrated in the fusion transcript (Fig. $3.25 \mathrm{C}$ ). The variation in the expression of the gene trapped allele in testis of fertile and infertile $\mathrm{Fafl}^{\mathrm{GT/+}}$ mice lead us to study the expression of $\mathrm{Fafl}^{G T}$ allele in different tissues of fertile and infertile $\mathrm{Fafl}^{G T /+}$ mice. The expression level of the $2.8-\mathrm{kb} \mathrm{Fafl}^{+}$transcript is higher than that of the $3.5-\mathrm{kb} \mathrm{Faf1}{ }^{G T}$ transcript in all examined tissues of fertile $\mathrm{Fafl}^{G T /+}$ mice $(3.24 \mathrm{E})$. In contrast, the expression level of the $3.5-\mathrm{kb} \mathrm{Fafl}^{G T}$ transcript is prominent in all studied tissues of infertile $\mathrm{Fafl}^{\mathrm{GT/+}}$ mice (Fig. 3.24 F). 

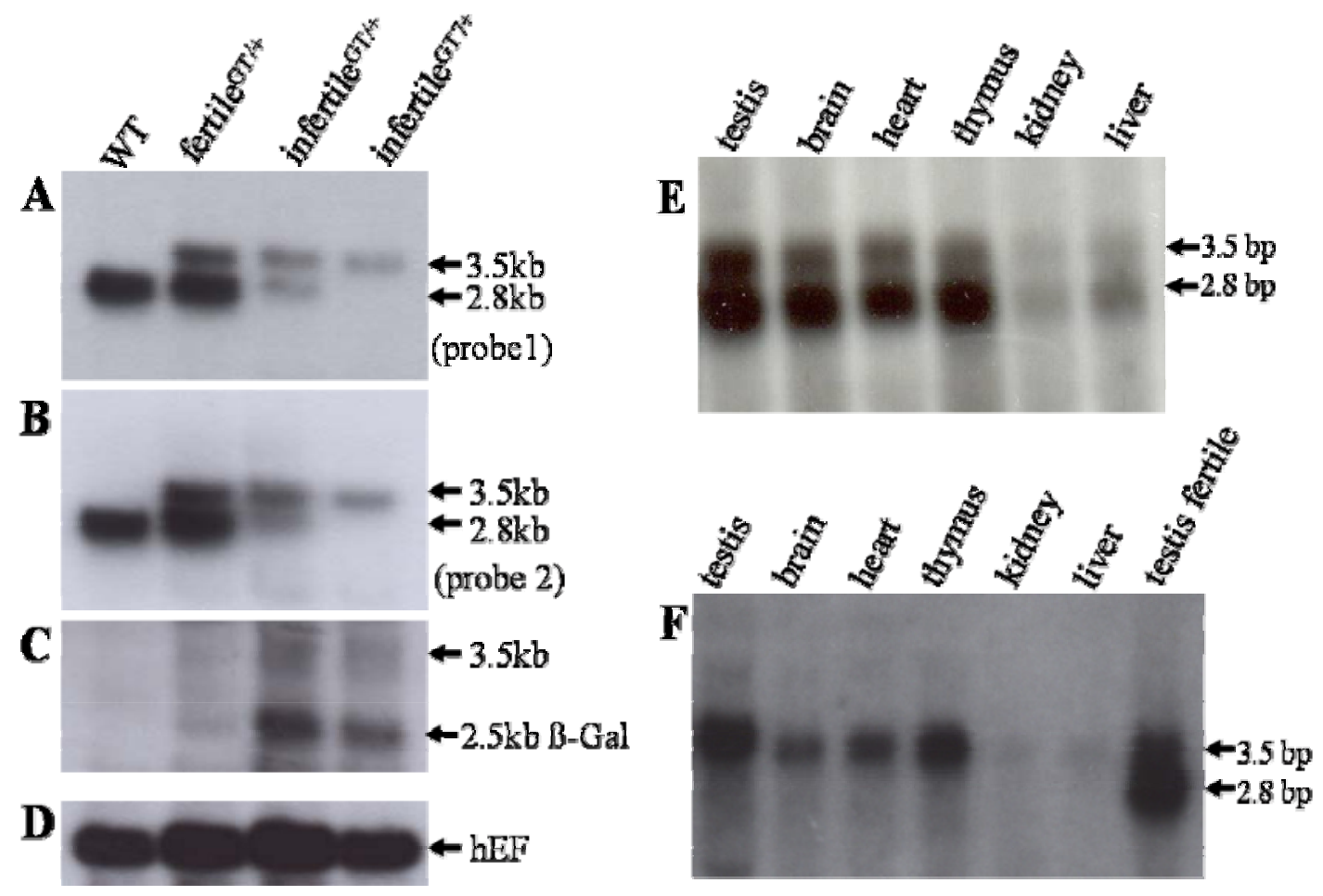

Figure 3.24 (A) Northern blot analysis with RNA from wild-type (WT), fertile and infertile $\mathrm{Fafl}^{\mathrm{GT/+}}$ animals. Testicular RNA was hybridized with Fafl cDNA probes locating at 5' (A) and 3' (B) of the integration site of gene trap vector. (C) Rehybridization of blot with LacZ probe. LacZ probe recognizes a very weak $3.5-\mathrm{kb} F a f 1^{G T}$ transcript and detects an additional transcript of $2.5-\mathrm{kb}$ in RNA of fertile and infertile $F a f 1^{G T /+}$ mice. (D) Rehybridization of Northern blot with the human elongation factor (EF) to confirm an equal amount of loading RNA. Expression of the 3.5-kb Fafl ${ }^{G T}$ and the 2.8-kb $\mathrm{Fafl}^{+}$ transcript in different tissues of fertile (E) and infertile (F) Fafl ${ }^{G T /+}$ mice. 
To determine the molecular origin of the fusion transcript, RT-PCR analysis using primers located in the Fafl gene and in the gene trap vector was performed. Primers were located in IRESF1 of the gene trap vector and in exon 14 of the Fafl gene (Fig. 3.25 C). Using the primers UBAR and IRESF1 located in the IRES sequence of the gene trap vector and in exon 14 of Fafl gene, respectively (Fig. 3.25 A) a 920-bp PCR fragment could be amplified with testicular RNA of $\mathrm{Fafl}^{G T /+}$ mice. The PCR fragment was then subcloned in to pGEMT easy vector and sequenced. Sequence analysis revealed that the amplified fragment contains an 82-bp of the IRES sequence of gene trap vector and 838-bp of the Fafl cDNA sequence (Fig. 3.25 A). Alignment of the 82-bp sequence with that of IRES sequence revealed the presence of cryptic exon/intron donor site (GT) in the IRES sequence. This cryptic donor site (GT) is located 3' downstream of the 82-bp in IRES sequence (Fig. $3.25 \mathrm{~B}$ ). Alignment of the sequence of RT-PCR fragment with that of the Fafl gene showed that the sequence of Fafl in the amplified fragment starts with the sequence of exon 8 . This result suggests that the amplified fusion transcript is the result of splicing the 82-bp of IRES sequence with exon 8 of the Faf1 using a cryptic donor site in the IRES domain of the gene trap vector.

To identify the 5' sequence of gene trap vector in the $3.5-\mathrm{kb}$ fusion transcript, several forward primers located in 5' exons of Faflgene and reverse primers locating in the IRES domain of gene trap were used in RT-PCR assay with testicular RNA of Faf1 ${ }^{G T /+}$ mice. RT-PCR analysis could not detect any specific product. 
IRES I'1

TARCARAGAGGACARGCGECCTCGCACAGCCTPCACTGCPGAGCRGCTCCAGAGG rafl Exon :

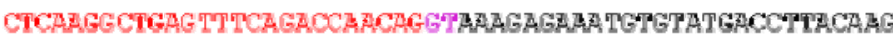
CATACCTETTCGACATCAGTTATGGGAGGGCTGECCAGCTT TGCCACCGATGAC TCAAT GT GTCTTGCTGAAPCAGGCCTCPCTPAPOCCTGCCATOGATPAACTGTG GAAGAAGAACTT CACCTGTACAGAOCCGTGAGCAATCAGAAGAGCAAAGCACGGA TETTCATATGGT TAGTGAPAGTGATEGCGATGACTPT GAAGA TGCTPCAGARTPT GGAGTGGATGACGGAGAAGTATTTGGCATGECAT

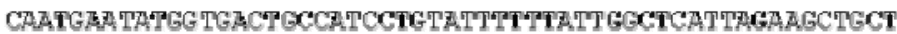

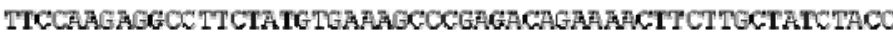

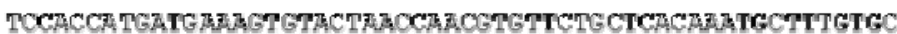
TGAATCCATTGT TTCCTARCTGAGTCAAAATTTATAACCTGGGCTTGGATCTE ACARAGGACACO RACAGAG CRAGATTCTGACAATGT GCAATAGACACTITGGCA GCETTAT TGCACADACTATTCGGACTCAAPAGACAGATCAG TTTCCACTTTTCC

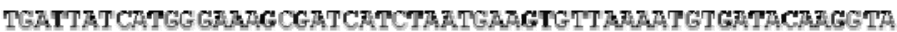
TPCAACAG

B

IRES TS - TRES II

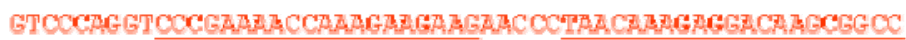
TECACAECCTTCACTECTGAGCAGCOCAGAG GCTCAAGECTGAGTTCAGACCA Sक $3 \mathrm{R}$

ACAGGIACXTGACAGAGCAGCGGCGCCAGAGT CTEGCACAGXXXXTCEGTACECG

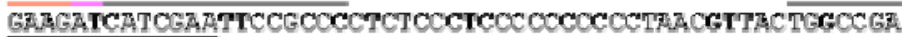
SH2 $\mathrm{N}$ SHI R

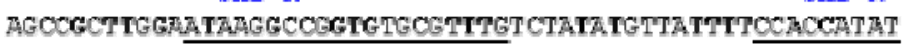
IRES F 2

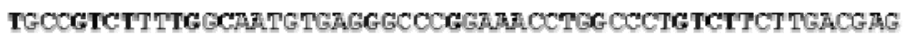
CATCCTAGGGECTTCCCCTCTCGCCAAAGGATGCADGGTCTGTTGARTGCG

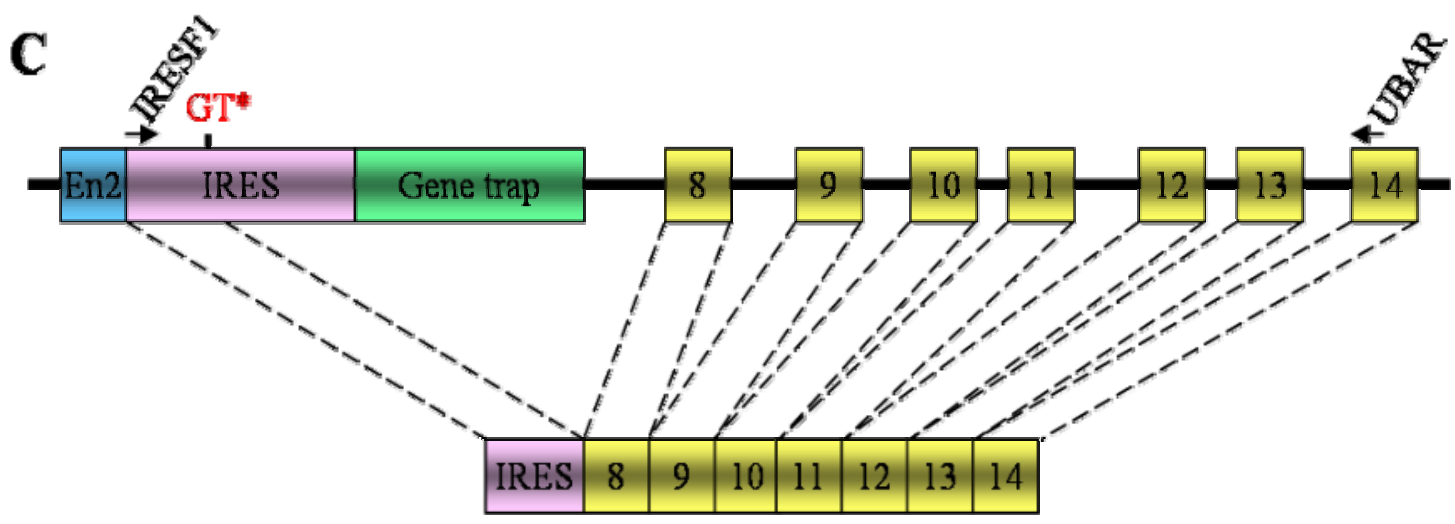

Figure 3.25 (A) Sequence of the amplified 920-bp fragment. Red letters represent the integrated IRES sequence. Letters in black are Fafl cDNA sequence. (B) A partial sequence of IRES region of gene trap vector. Red letters represent the integrated sequence in the amplified fragment. Unterlined GT represent the cryptic donor site. (C) Schematic diagrams represent the position of sequences in gene trap vector and Fafl gene, which are identified in the 920-bp amplified fragment. 


\subsubsection{Faf1 protein analysis}

\section{Identification of the interaction partner of Faf1}

Alignment of the amino acid sequence in the Database reveals that Fafl protein possesses UBA (ubiquitin-associated) and the UBX (ubiquitin like) domains. UBA and UBX domains are located at position 335 to 480 and 569 to 647 of the Faf1 sequence (Fig. 3.26), respectively.

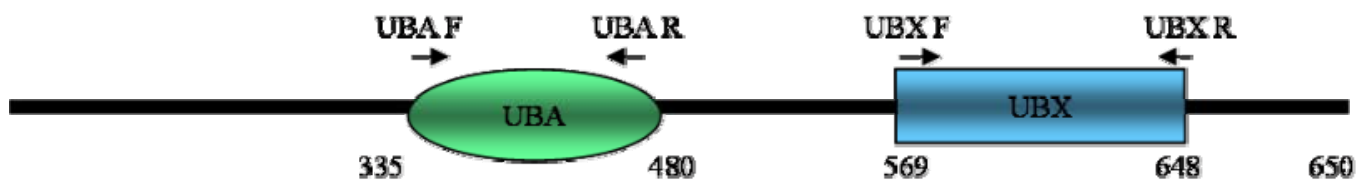

Figure 3.26 Schematic diagram represents the positions of the ubiquitin-associated (UBA) and the ubiquitin like domain (UBX) in the Faf1 protein. Position of primers used for the amplification of the UBA and UBX cDNA fragments are marked.

Three proteins, shp1, Ubx2 and Ubx5 in Saccharomyces cerevisiae and the $\mathrm{p} 47$ protein in mammalian species contain both domains. All these proteins have been shown to bind to ubiquitinated proteins through the UBA domain and UBX domain is utilized for interaction with ATPase p97/Cdc48 protein. The VCP/ATPase p97 is an abundant and widely expressed protein, and is a member of the AAA family of ATPases.

To identify the proteins that interact with the UBA and UBX domains of Faf1, GSTpulldown assay was performed. Using testis cDNA and primers shown in figure 3.26. cDNA fragments containing the sequences of UBA and UBX-domain were amplified and subcloned into BamHI/SacI digested pET41a vector for the expression of the GST-fusion protein in E. coli. The GST-UBA and GST-UBX fusion constructs were transformed into competent cells BL21 and expression was induced by IPTG for $6 \mathrm{~h}$ at $37^{\circ} \mathrm{C}$. Recombinant GST-fusion proteins were purified on glutathione-sepharose beads. The expected 64-kDa GST-UBA and 45-kDa GST-UBX fusion proteins were separated by running the fusion proteins in SDS PAGE (Fig. 3.27 A). Then fusion proteins were transferred on nitrocellulose membrane. Membrane was incubated with the polyclonal anti-Fafl antibody, 
which recognizes the C-terminal domain of Faf1. As shown in figure 3.31 (B), the Faf1 antibody recognized the $45-\mathrm{kDa}$ GST-UBX fusion protein, but not the GST-UBA protein. The results confirm that the commercial anti-Fafl antibody specifically recognizes the Cterminal domain of the Fafl protein. To identify UBX-binding protein, protein extracts from testis and brain were used. GST pulldown assay was performed by incubation of 500 $\mu \mathrm{g}$ total protein with $100 \mu \mathrm{g}$ of GST-fusion protein, which was immobilized on glutathione-sepharose beads. After incubation for $4 \mathrm{~h}$ at $4^{\circ} \mathrm{C}$, the captured proteins were centrifuged and the beads were washed three times in lysis buffer. Samples were boiled in SDS electrophoresis sample buffer and centrifuged. Protein was analyzed on 10\% SDS PAGE. Protein bands were visualized by Coomassie blue staining. As shown in figure 3.27 (C), the 45-kDa GST-UBX fusion protein interacts with a 96-kDa protein in both assays with the testis and brain protein extracts. In the control GST pulldown assay, the GST protein was not bound to the $96-\mathrm{kDa}$ protein (Fig. 3.27 C). This result suggests that the UBX-domain interacts with the $96-\mathrm{kDa}$ protein. To determine the sequence of the $96-\mathrm{kDa}$ protein, fusion protein was transferred to a polyvinylidene difluoride membrane and stained with Coomassie blue. The $96-\mathrm{kDa}$ protein band was eluted from membrane and subjected to digestion with trypsin. Tryptic peptides were analyzed by mass spectrometry (in collaboration with Dr. B. Schmidt, Institute of Biochemistry II, Göttingen). The 96-kDa protein was identified as Valosin-containing protein (VCP) (NCBI accession number 6005942) by peptide mass fingerprinting using MALDI-TOFMS and confirmed by sequencing using ESI-q-TOF tandem MS. 

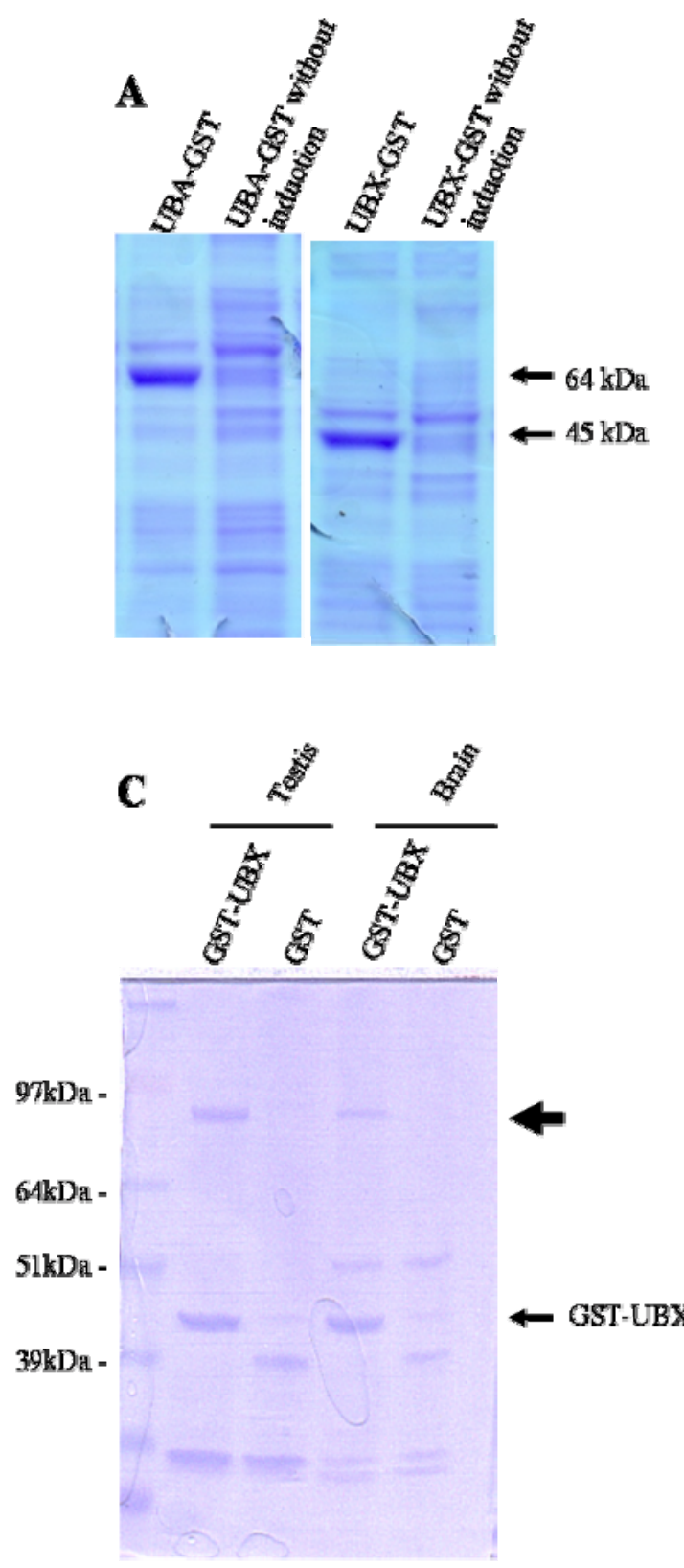

\section{B

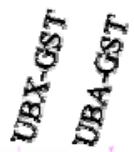

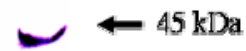

D

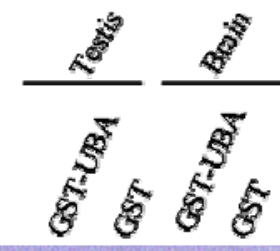

$97 \mathrm{kDa}-$

$64 \mathrm{kDa}=$

$51 \mathrm{kDa}$ -

$39 \mathrm{kDa}-$

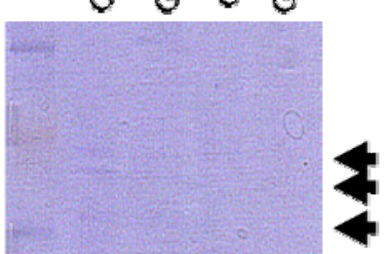

-GST-UBA

Figure 3.27 (A) SDS PAGE analysis of protein extract from recombinant UBA-GST and UBX-GST bacteria before and after induction of expression recombinant plasmid. (B) GST-UBA and GST-UBX fusion proteins were detected by the anti-Fafl antibody. The anti-Fafl antibody recognizes only the 45-kDa GST-UBX fusion protein. (C) SDS PAGE analysis of the GST pulldown assays shows that the GST-UBX fusion protein specifically interacts with a 96-kDa protein in protein extracts from testis and brain. (D) SDS PAGE analysis of the GST pulldown using the UBA-GST fusion protein shows the interaction of UBA-GST with multiple proteins in extracts of testis and brain. 


\section{DISCUSSION}

Gene trap methodology involves the random integration of a gene trap vector into a host genome, thereby trapping a gene. Gene trap insertion is a powerful mutagenesis technique, which can provide data on gene function and expression. Most of gene trap vectors contain a strong splice acceptor site 5' of the reporter. Upon integration into a genomic locus, the gene trap vector acts as an artificial exon and is spliced to the endogenous gene to form a fusion transcript (Fig. 1.1). The fusion transcript between the reporter and the endogenous gene is a reporter of endogenous gene expression and aids gene identification. The $L a c Z$ gene trap vector, which contains a $\beta$-galactosidase and neomycin phosphotransferase gene fusion transcript, is a widely used example of a gene trap vector.

The aim of this study was the characterization of gene trap line $98-2 \mathrm{C}$, in which the trapped gene is highly expressed in testis. Screening of the genomic library, which has been constructed from DNA of gene trap line $98-2 \mathrm{C}$, revealed that the integration site of gene trap vector is in the intron 7 of Fafl gene. This result lead us to determine the expression pattern of Fafl and consequence of Fafl gene trapped on the development of Fafl ${ }^{G T / G T}$ animals.

\subsection{Expression analysis of the Faf1 gene}

Northern blot analysis revealed that the Fafl gene transcribes a $2.8-\mathrm{kb}$ mRNA in all studied tissues. The 2.8-kb Fafl transcript is present at high level in the testis and moderate levels in other tissues (Fig.3.1). Fafl transcripts shorter than 2.8-kb were not detected in any tissues by Northern blot hybridization using 5' and $3^{\prime}$ cDNA probes and RT PCR assay. However, Western blot analysis revealed that the anti-Faf1 polyclonal antibody recognizes a protein with molecular weight of $74-\mathrm{kDa}$ in extract of all tissues and a further smaller protein product of $49-\mathrm{kDa}$ in testicular extract (Fig. 3.2). The $74-\mathrm{kDa}$ protein corresponds well with the deduced protein size of $73.8-\mathrm{kDa}$ based on the predicted amino acid sequences of mouse Faf1. Identification of only one transcript of Fafl suggests that the $49-\mathrm{kDa}$ protein would be proteolytically cleaved product of $74-\mathrm{kDa}$ Fafl or it could be a Faf1 homologous protein. Using another polyclonal antibody against human FAF1, it was reported that anti-human FAF1 antibody recognized 74- and 40-kDa proteins in different cancer cell lines (Ryu et al., 1999) and in samples from human solid tumors. Jensen et al. 
(2001) have overexpressed the human Fafl cDNA in bacteria. After protein purification, they found two Fafl protein products of 74- and 40-kDa. Peptide sequence of the $40-\mathrm{kDa}$ band revealed that $40-\mathrm{kDa}$ contains sequence of the $74-\mathrm{kDa}$ Fafl protein. Furthermore, this group has found in phoshorylation assay that both Fafl products are phosphorylated by protein kinase CK2. Identification of lower weight protein in testicular extract using the anti-mouse Faf1, which was raised against the C-terminal region, suggests that the 49-kDa protein would be proteolytically processed product of $74-\mathrm{kDa}$ protein and contain the Cterminal region. Our approach to purify and sequence the $49-\mathrm{kDa}$ protein by immunoprecipitation using Fafl antibody was not successful.

Expression pattern of Fafl during testis development revealed that the expression level of the Fafl gene is highly increased at day 25 (Fig. 3.3). At the protein level, an equal expression of the $74-\mathrm{kDa}$ isoform was detected throughout testicular development. In contrast, the $49-\mathrm{kDa}$ protein could not be detected in mouse testes till postnatal day 21 . The expression of the $49-\mathrm{kDa}$ isoform could be first detected at day 25. Thereafter, an increasing level of 49-kDa protein was observed (Fig. 3.5). During mouse spermatogenesis, the first wave of spermatogonia enters meiosis and gives rise to spermatocytes at $\sim 10$ days after birth. The primary spermatocytes undergo two meiotic divisions at $\sim 17$ days of age. The correspondence of these events with the correlated increase of Fafl transcript and appearance of the $49-\mathrm{kDa}$ protein suggests that the $49-\mathrm{kDa}$ isform is a result of posttranslational modification of $74-\mathrm{kDa}$ Fafl precursor in haploid spermatid. Immunohistochemistry revealed that the most intense Fafl immunoreaction was in haploid spermatids (Fig. 3.8). High level of Fafl was found in cytoplasm of elongated spermatids, while Faf1 was diminished in mature spermatids (Fig. 3.9). These expression pattern and the results shown the high accumulation of Faf1 in multinuclear giant cells (Fig. 3.8; 3.9), which undergoe cell death, suggest that Fafl protein is involved in the ubiquitin-dependent protein degradation pathway during spermatid differentation and in apoptotic germ cells.

\subsection{Functional analysis of Faf1 gene.}

To investigate the physiological role of Fafl, the gene trap line 98-2C was analysed. Cloning of trapped allele of the mouse line $98-2 \mathrm{C}$ revealed that the gene trap vector is inserted in the intron 7 of Fafl gene. Genotyping of the progeny of heterozygous intercrosses indicated the absence of $\mathrm{Fafl}^{G T / G T}$ pups and suggested an embryo-lethal 
phenotype. Genotyping of preimplantated embryos from heterozygous intercrosses revealed that the early embryonic development failure of $\mathrm{Fafl}^{G T / G T}$ can be detected past 2cell stage. These results suggest the essential role of the Fafl for cell viability and/or cell division. The ability of the Fafl ${ }^{G T / G T}$ to undergo cell division till 2-cell stage can be interpreted by presence of maternal Fafl protein, which would replace the absence of zygotic Fafl protein. Immunofluorescence staining showed that the Fafl protein is present in oocytes in the ovary (Fig. 3.10), in unfertilized oocytes and all preimplantation stages of embryonic development (Fig. 3.11). This could indicate that the Fafl protein is present in oocytes of mothers with an intact gene copy and may be transferred to and used by early embryonic cells during the first rounds of division. The persistence of maternally produced Faf1 protein in the embryo could explain the normal development of Faf1 ${ }^{G T / G T}$ to the 2-cell stage despite deletion of the Fafl gene in the embryo. Embryo expression of Fafl becomes appreciable at the 4-cell stage as assessed by RT-PCR (Fig. 3.20). Thus, the death of Faf1 ${ }^{G T / G T}$ embryos may coincide with depletion of maternal Faf1 in these embryos. Morphological analysis of embryos at early morula stage, which were isolated from heterozygous intercrosses, suggests that loss of Fafl leads to massive cell death (Fig. 3.18). However, TUNEL assay did not reveal TUNEL-positive cells in necrotic embryo. Therefore, it could not be excluded that Fafl deficiency could led to cell death by a nonapoptotic pathway such as necrosis. Necrosis is known to follow rapid loss of cellular homeostasis and necrotic cells are characterized by swelling due to accumulation of water and electrolytes (Saraste et al., 2000). Apoptosis and necrosis share common mechanisms in the early phase of cell death, particularly the involvement of BCL-2 family members that control mitochondrial events, a critical step to commitment to both apoptotisis and non-apoptosis of cell death. Moreover, in some circumstance, apoptosis can progress into secondary necrosis (Saraste et al., 2000). Therefore, further investigations are needed to determine whether Fafl deficiency lead to apoptosis and/or to a non-apoptotic death of preimplantation embryos.

During breeding of heterozygous Fafl mutants, we found some infertile $\mathrm{Fafl}^{G T /+}$ males. Histological analysis revealed that the diameter of the seminiferous tubules was significantly shorter in testis of the infertile males, and the luminas of the tubules were filled with a mass of Sertoli cells and germ cells were completely absent (Fig. 3.21). In addition, Leydig cell hyperproliferation was apparent. This is likely a secondary defect owing to shrinkage of seminiferous tubules. In some infertile $\mathrm{Fafl}^{\mathrm{GT} /+}$, which are younger than 6-month-old, all stage of spermatogenesis were observed in very few tubules (5-10\%) 
(data not shown). These observations suggest a gradual loss of germ cells in testis of infertile $\mathrm{Fafl} \mathrm{GT/}^{G T+}$ males feat and the germ cell depletion is not germ cell stage specific. Such pattern of germ cell loss has been reported to be due to a problem of supporting Sertoli cells rather than a specific and direct developmental arrest of germ cells (Russell et al., 1990). TUNEL assay did not shown an increase of apoptotic-positive cells in testis of infertile Fafl ${ }^{G T /+}$ males (Fig. 3.22). This result suggests that the germ cell death like as the death observing in Faf1 ${ }^{G T / G T}$ embryos is due to non-apoptotic pathway. Non-apoptotic death of post-meiotic germ cells was observed in testes of mice lacking $C \operatorname{snK} 2 a 2$ gene, which encodes the CK2 $\alpha$ subunit of protein kinase CK2 (Escalier et al., 2003). Interestingly, the protein kinase CK2 has been shown to interact with and phosphorylate the Faf1 protein (Kusk et al., 1999; Jensen et al., 2001). CK2 is a tetrameric protein and consists of beta-alpha dimer. The CK2 $\beta$ subunit is responsible for the interaction with the Faf1 (Kusk et al., 1999). Inactivation of the gene encoding the $\mathrm{CD} 2 \beta$ subunit leads to early embryonic lethality (Buchou et al., 2003). Therefore, it is interested to further investigate the interaction between CK2 and Fafl, and the significance of Faf1 phosphorylation for its function. To determine the cause of germ cell depletion in testes of infertile $\mathrm{Fafl}^{G T /+}$ mice at molecular level, expression of wild-type and $\mathrm{Fafl}^{\mathrm{GT/+}}$ mice was analysed. These analyses revealed that the expression level of the fusion transcript deriving from trapped allele was higher than that of wild-type allele. In testes of some infertile heterozygotes, trapped transcript was prominent in testes (Fig. 3.24). In contrast, the expression level of the wild-type allele was higher than that of trapped allele in testis of fertile Faf1 ${ }^{G T /+}$ animals. These results suggest that the haploinsuficiency of Fafl in some Fafl ${ }^{G T /+}$ causes the germ cell loss.

\subsection{Faf1 is involved in the ubiquitin-proteasome pathway}

Faf1 was firstly identified by yeast two hybrid system using the cytoplasmic domain of Fas as bait (Chu et al., 1995). Its function has been described as potentiating Fas -induced apoptosis in a mouse fibroblast cell line and in a human T-cell tumor line (Jurkat) (Chu et al., 1995). However, Ryu and Kim (2001) reported that the Fafl overexpression in BOSC23 cells can initiate apoptosis in the absence of an extrinsic death signal. Unlike other Fas-associating proteins, Fafl does not contain a death domain, but has several homologous domains based on amino acid sequence analysis. The Fafl protein contains an 
UBA (ubiquitin- associated) domain and a UBX (ubiquitin-like) domain. Both domains are well characterized in mammalian protein p47 (Dreveny et al., 2004), and UBX proteins of S.cerevisiae (Buchberger et al., 2002; Schuberth et al., 2004). The UBA domain in p47 and in yeast UBX proteins binds ubiquitinated proteins in vivo (Meyer et al., 2002 and Schubert et al., 2004). The UBX domain in $\mathrm{p} 47$ and yeast proteins binds to the mammalian $\mathrm{p} 97 / \mathrm{VCP}$ (Cdc 48 in yeast). VCP/p97 is an abundant and widely expressed protein, and is a member of the AAA family of ATPase. Disruption of the Cdc48 gene in yeast (Moir et al., 1982) or that encoding the Drosophila homologue TER94 (Leon and McKearin, 1999) is lethal, indicating that $\mathrm{Cdc} 48$ plays roles essential for cell growth and survival. VCP/p97 does not itself bind to polyubiquitinated proteins (Wilkinson et al., 2001). The interaction of the p47 with $\mathrm{VCP} / \mathrm{p} 97$ and polyubiquitinated proteins led to suggest that $\mathrm{p} 47$ function as an adaptor to couple VCP/p97 to polyubiquitinated proteins and proteasome (Fig. 4.1). Polyubiquitinated proteins are themselves known to interact with the S5a subunit of the 19S component of the proteasome (Deveraux et al., 1994). The role of VCP/p97 itself may be to promote the ATP-dependent unfolding of polyubiquitinated proteins, thereby stimulating their distruction by the proteasome. The ATPase activity of $\mathrm{VCP} / \mathrm{p} 97$ provides the energy required for this process (Golbik et al., 1999).

In this report, we found that the UBX domain of Faf1, like p 47, was able to bind to $\mathrm{VCP} / \mathrm{p} 97$ in extracts of testis and brain (Fig. 3.2). While this work was in progress, it was reported that UBX and UBA domains interact with $\mathrm{VCP} / \mathrm{p} 97$ and multiubiquitinated substrates, respectively (Song et al., 2005). These results suggest that Faf1 protein serves as an adaptor protein that regulates protein degradation in the ubiquitin proteasome pathway. 


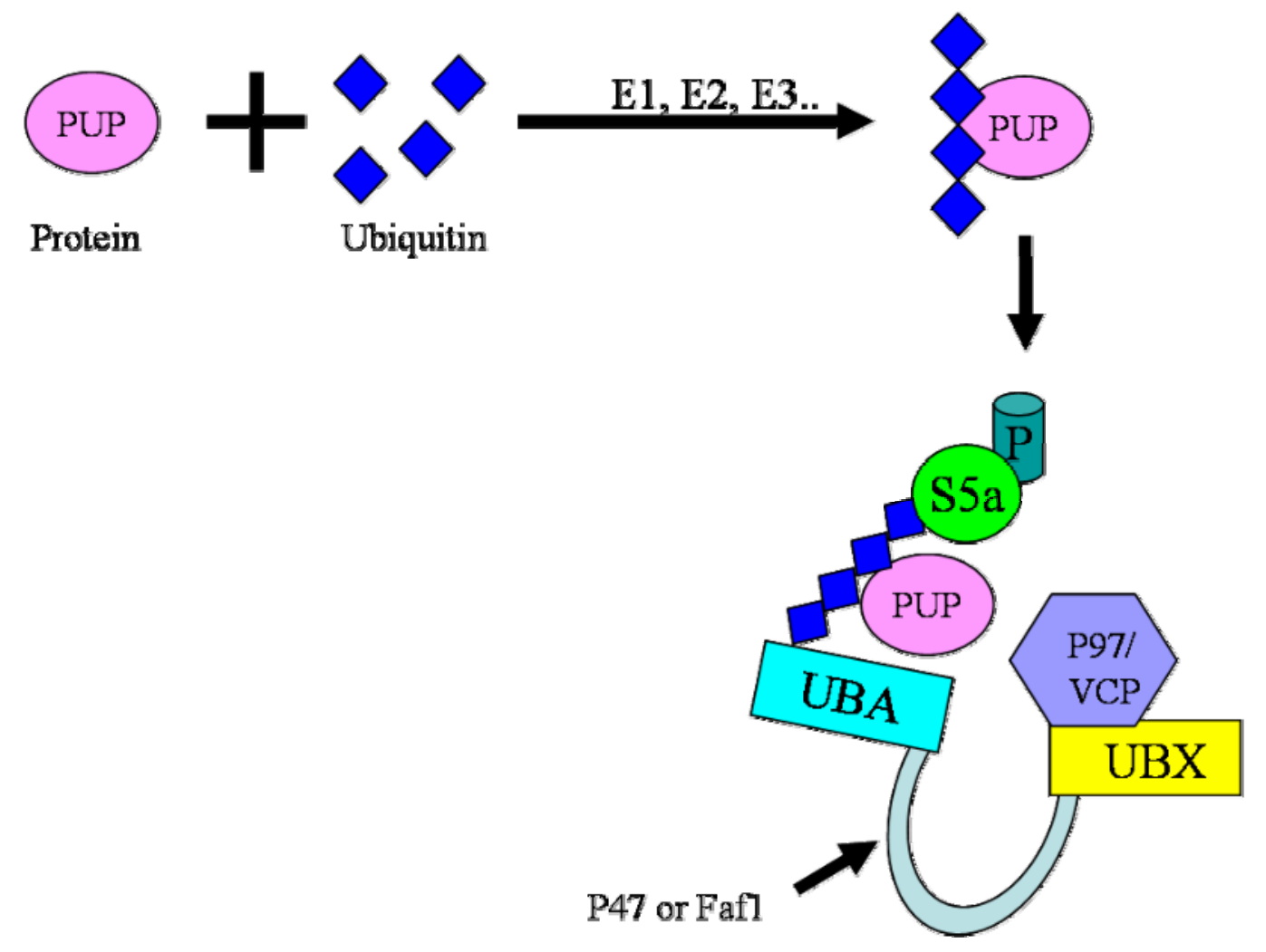

Figure 4.1 Schematic representation of the proposed role of p47 and Faf1 in localizing $\mathrm{VCP} / \mathrm{p} 97$ to ubiquitinated proteins. Ubiquitin dependent protein degradation starts with labeling the protein with the ubiquitin. There are three types of enzymes E1, E2 and E3, which are involved in ubiquitination of proteins. The polyubiquitinated protein PUPs binds to the protein adaptor p47 or Faf1 via the polyubiquitin chain. On other side, the VCP/p97 interacts with the UBX domain of $\mathrm{p} 47$ or Fafl. The $\mathrm{VCP} / \mathrm{p} 97$ is then directed to polyubiquitinated protein (PUPs) via the adaptor protein (p47 or Faf1), allowing VCP/p97 to unfold PUPs in an ATP-requiring process. PUPs can then be degraded by the proteasome, with which they interacts via S5a subunit of the proteasomal subunit $(\mathrm{P})$.

\subsection{Ubiquitin in preimplantation embryonic development}

Ubiquitin is likely to be expressed in mammalian gametes and embryos at any given developmental step, but the information on ubiquitin dependence of gametogenesis and fertilization is sketchy. Mammalian preimplantation embryo development passes through four important stages following fertilization, degradation of oocyte transcripts, transcriptional activation of the zygotic genome, compaction, and differentiation into inner cell mass and trophectoderm. In mouse, the first two events occur at the 1-cell stage, 
compaction occurs at the 8-cell stage, and differentiation at the blastocyst stage (Piko and Clegg, 1982; Schultz, 1993). Analysis of gene expression profiling (Meta-analysis) using the distribution of expressed sequence tags (EST) in cDNA libraries derived from mouse preimplantation embryos identified 11483 genes. These genes are expressed in preimplantation embryo development and included 1585 that are not expressed elsewhere in the mouse. Over 100 genes are expressed in a stage-specific manner (Stanton and Green, 2001). Ubiquitination is likely to be of major importance in early embryogenesis because of the need for each developmental stage to eliminate proteins that are destined for transient expression. Early developmental programs rely on maternal mRNAs and proteins that are synthesized during oogenesis. The regulated translation of maternal RNAs is essential for the proper deployment of regulatory factors during early embryogenesis. Recent studies suggest that the degradation of maternal proteins by the ubiquitinproteasome pathway is also crucial during oocyte-to-embryo transition and degradation of germ line proteins is essential for remodeling the oocyte into a totipotent zygote that is capable of somatic development. The complex phenotypes observed in C. elegans zygotes that lack various components of the ubiquitination machinery suggest that protein degradation regulates many developmental events in early embryos (Feng et al., 1999; Kurz et al., 2002; Pintard et al., 2003; Sonneville and Gonezy, 2004). A mutation affecting the PBF1 gene encoding the $\beta 6$-subunit of the Arabidopsis 26S proteasome CP appears to be lethal, whereas the heterozygous plants are healthy, seeds homozygous for the pbfl mutation cannot be recovered. Loss of the Arabidopsis DUB that likely helps to disassemble free polyUb chains (AtUBP14) induces early embryo arrest (Doelling et al., 2001; Tzafrir et al., 2002). The mutant embryos accumulate abnormally high levels of free polyUb chains, presumably inhibiting competitively substrate degradation by the $26 \mathrm{~S}$ proteasome (Doelling et al., 2001).

\subsection{Ubiquitin-proteasome degradation pathway and gametogenesis}

Ubiquitin appears to have specialized functions in mammalian gametogenesis (Baarends et al., 1999). Ubiquitin mediated proteolysis is also critical for other aspects of reproduction, including the elimination of defective sperm in the epididymus, clearance of paternal mitochondria, and progression of embryonic development in mammals, as well as degradation of the vitelline coat during fertilization in ascidians (Sutovsky et al., 2000; 
Sutovsky et al., 2001; Li et al., 2002; Sawada; 2002). There are tree well established types of enzymes involved in ubiquitination, termed E1, E2 and E3. E1 is the ubiquitin-activating enzyme, which forms a thiol-ester linkage with ubiquitin through its active site cysteine. Ubiquitin is subsequently transferred to an E2 ubiquitin-conjugating enzyme. The E3 enzyme is the ubiquitin protein ligase, which transfers ubiquitin from the E2 enzyme to lysines of a specific protein, targeting the protein for degradation by the proteasome. More recently, E4 enzymes have been described that appear to function in ubiquitn chain polymerization (2). Few E1 enzymes, several E2 enzymes, and hundreds of E3 enzymes have been identified. It is the E3 ubiquitin protein ligase that adds specificity to the process by interacting with specific target proteins. Included in the group of E3 enzymes are proteins such as the cancer-associated proteins, anaphase-promoting complex (APC), BRCA1, and MDM2, and the DNA repair proteins, RAD5 and RAD18 (Nobuhiro et al., 2003).

Mouse gene knockout studies have shown that inactivation of components of the ubiquitin system leads to impaired gametogenesis (Roest et al., 1996). Mutations in the human gene ubiquitin-specific protease 9 Y chromosome (USP9Y), which encodes a protein with a Cterminal ubiquitin hydroxlase domain, results in azoospermia and male infertility (Sun et al.,1999). Knockout mice lacking the E3 ubiquitin protein ligase SIAH1A or the E2 ubiquitin-conjugating enzyme HR6B demonstrate defects in meiosis and postmeiotic germcell development and have male infertility (Dickins et al., 2002; Roest et al., 1996). Yeast mutants heterozygous for a deletion of the polyubiquitin gene show reduced viability of spores, and homozygous mutants are sporulation defective (Finley et al., 1987). Ubiquitination of somatic histones has been implicated in their turnover during spermatogenesis (Baarends et al., 1999). Recently, Sutovsky et al., (1999) have shown that uniparental ubiquitin-tagging of mitochondria during spermatogenesis selectively targets sperm mitochondria for postfertilization degradation by proteasomes and lysosomes of the embryo.

Maturation-promoting factor (MPF), a heterodimer of p34Cdc2 kinase and cyclin B1, is a key regulator of oocyte meiosis that functions during discrete periods of the cell cycle. MPF activity increases during prophase and metaphase of meiosis I because of increased translation of cyclin B1 mRNAs and the dephosphorylation of p34Cdc2 in complexes with cyclin B1. As oocytes progress through meiosis I, MPF is transiently inactivated by the proteasomal degradation of cyclin B1 (Sawada, 2002; Holloway et al., 1993). Subsequently, translation of several key oocyte mRNA (e.g., cyclin B1 and Mos) and activation of Cdc2 
kinase by $\operatorname{Cdc} 25$ phosphatase occur, so that MPF activity is high in metaphase II. Eggspern fusion at fertilization releases the oocyte from metaphase II arrest by increasing $\mathrm{Ca}^{2+}$ levels, activating $\mathrm{Ca}^{2+}$-calmodulin kinase II, and targeting cyclin B1 and MOS for degradation via the ubiquitin proteasome pathway (Glotser et al., 1991; Lorca et al., 1993; Tokumoto et al., 1997).These studies indicate that specific ubiquitination pathways regulate MPF at several key transitions in oocyte meiosis (Nobuhiro et al., 2003).

The high expression of Fafl gene in haploid spermatid suggests the role of Fafl during spermatid maturation. The early embryonic death of $F a f 1^{G T / G T}$ prevents us to study the role of Fafl during spermatogenesis. The germ cell depletion shown in some Fafl ${ }^{G T /+}$ can be explained by one of the following cases. 1-The haploinsufficiency of $\mathrm{Fafl}^{1+}$ allele in some heterozygous animals. 2- The $\mathrm{Fafl}^{G T}$ allele, in which the gene trap vector integrates in intron7, encodes a truncated protein lacking the UBA and UBX domain. This truncated protein might have negative dominant defect in some $\mathrm{Fafl}^{G T /+}$ animals. Such negative dominant effect has been shown by overexpression of the truncated Faf1 protein lacking the UBA domain in the HEK293T cell line (Song et al., 2005). Overexpression of truncated Fafl protein induces cell death. Such cell death has been attributed to inhibition of the degradation of ubiquitinated proteins in transfected cells (Song et al., 2005). However, truncated Fafl protein was not detected by Western blot analysis with testicular protein extracted from the fertile and infertile $F a f 1^{G T /+}$. Production of conditional knockout mice may be the most promising method for the direct assessment of the function of Faf1 during embryogenesis and spermatogenesis.

\subsection{Mutation cause of preimplantation embryonic death in other genes}

The very early preimplantation development depends entirely on maternal mRNAs and proteins deposited and stored in the oocyte prior to its ovulation. If oocyte is not sufficiently equipped with maternally stored products, or if zygotic gene expression does not commence at the correct time, the embryo will die. Many developmental targets and regulators are identified; it should become possible to separate the cell cycle and the developmental function of protein degradation. Mutations in some genes have been found, which lead to lethality in preimplantation development. Mice with a homozygous gene trap vector insertion in mgcRacGap die during preimplantation development. MgcRacGap protein is a GTPase-activating protein and was identified first in human. In the mouse, 
maternally derived protein was found to be present in the oocyte and mgcRacGap transcription starts at the four-cell stage. E3.5 $\mathrm{mgcRacGap}^{-/-}$embryos display a dramatic reduction in cell number, but undergo compaction and form blastocyst. At 3.0-3.5, binucleated blastomers with nuclei partially interconnected are frequently observed, suggesting that mgcRacGap is required for normal mitosis and cytokinesis in the preimplantaion embryo. Severe phenotype of null embryos indicates that mgcRacGap is functionally non-redundant and cannot be substituted by other GTPase-activating proteins (Van et al., 2001). Targeted disruption of the Rad51 gene leads to lethality in preimplantation embryos (Tsuzuki et al., 1996). The mouse Rad 51 gene is a mammalian homolog of the E.coli recA and yeast RAD51 genes. These genes are known to be involved in homologous recombination and DNA repair. Domain II of RAD51, which is conserved in RecA-related proteins, was targeted by homologous recombination. The high level of mouse Rad51 gene expression in testis, ovary, spleen, and thymus suggests that this protein might play an important role in meiosis (Shinohara et al., 1993). The neurogenic gene brainiac was first isolated in Drosophila melanogaster. It interacts with members of the Notch signalling cascade. The Notch signalling pathway has been implicated in cell fate decisions in a variety of developmental aspects in Drosophila melanogaster, Caenorhabtidis elegans, and in vertebrates. Targeted deletion of mouse Brainaic 1 expression leads to preimplantation lethality.

Study of genes which cause embryonic lethality in the mouse could be of value to understand human embryonic failure. In human, most miscarriages occur due to chromosomal aberrations. The rate of chromosomal aberrations decreases during embryonic development, from $37 \%$ in the fertilized oocyte to $0.6 \%$ in the newborn (Plachot et al., 1987). Due to chromosomal aberrations, $16.4 \%$ of preimplantation embryos fail to develop to further stages. Spontaneous abortion in human pregnancy occurs during the preimplantation period with a frequency of $\sim 30 \%$. Embryonic lethality in human not only depends on the chromosomal aberrations but could also depend on monogenic defects. In table 4.1 represents a list genes, whose inactivation result in preimplantation death in case of mutation. 


\begin{tabular}{|c|c|c|c|c|}
\hline $\begin{array}{l}\text { Name of the } \\
\text { gene }\end{array}$ & Expression & Function & $\begin{array}{l}\text { Day of the } \\
\text { embryonic } \\
\text { lethality }\end{array}$ & Reference \\
\hline$\gamma$-adaptin & Widely expressed & $\begin{array}{l}\text { Post-Golgi } \\
\text { vesicular transport } \\
\text { and sorting } \\
\text { processes }\end{array}$ & E3.5 & $\begin{array}{l}\text { Ziziolo et al., } \\
2000\end{array}$ \\
\hline ZarI & testis, ovary, oocytes & & E0.5 & Wu et al., 2001 \\
\hline$m g c R a c G A P$ & $\begin{array}{l}\text { preimplantaion } \\
\text { embryos, intra and } \\
\text { extra embryonic } \\
\text { tissues }\end{array}$ & GTP-ase activating & E3.5 & Van et al., 2001 \\
\hline Rad51 & $\begin{array}{l}\text { testis, ovary, spleen, } \\
\text { thymus }\end{array}$ & Cell proliferation & E2.5-E3.5 & $\begin{array}{l}\text { Tsuzuki et al., } \\
1996\end{array}$ \\
\hline BrainicI & $\begin{array}{l}\text { developing central } \\
\text { nervous system, } \\
\text { retina, adult } \\
\text { hippocampus, kidney, } \\
\text { ovary }\end{array}$ & Notch signalling & E3.5-4.5 & $\begin{array}{l}\text { V ollrath et al., } \\
2001\end{array}$ \\
\hline FenI & $\begin{array}{l}\text { epidermis, small } \\
\text { intestinal epithelium }\end{array}$ & $\begin{array}{l}\text { DNA repair as well } \\
\text { as DNA replication }\end{array}$ & E.3.5 & $\begin{array}{l}\text { Larsen et al., } \\
2003\end{array}$ \\
\hline$m u C d c 7$ & $\begin{array}{l}\text { ES cell, testis, spleen, } \\
\text { lung, thymus, } \\
\text { stomach, brain }\end{array}$ & DNA replication & E3.5-6.5 & $\begin{array}{l}\text { Kim et al., } \\
2002\end{array}$ \\
\hline$L t b 2$ & $\begin{array}{l}\text { testis, lung, dermis, } \\
\text { heart valves }\end{array}$ & $\begin{array}{l}\text { structural role } \\
\text { within elastic fibers }\end{array}$ & E3.5-6.5 & $\begin{array}{l}\text { Shipley et al., } \\
2000\end{array}$ \\
\hline ICLn & $\begin{array}{l}\text { ubiquitously } \\
\text { expressed }\end{array}$ & $\begin{array}{l}\text { regulation of the } \\
\text { cell cycle and RNA } \\
\text { processing }\end{array}$ & E3.5-7.5 & Pu et al., 2000 \\
\hline
\end{tabular}

Table 4.1 Mutations genes that result in preimplantation death. 


\section{Summary}

The aim of this study was the characterization of mouse gene trap line $98-2 \mathrm{C}$, in which the trapped gene is highly expressed in testis. Screening of the genomic library, which has been constructed from DNA of gene trap line 98-2C, revealed that the integration site of gene trap vector is in the intron 7 of Fafl gene. These results lead us to determine the expression pattern of the Fafl and consequence of Fafl gene trapped on the development of Faf1 ${ }^{G T / G T}$.

Northern blot analysis revealed that Fafl transcribes a $2.8-\mathrm{kb}$ mRNA in all studied tissues. The 2.8-kb transcript is present at high level in testis and moderate level in other tissues. Western blot analysis revealed that the anti-Fafl polyclonal antibody recognizes a protein with molecular weight of $74-\mathrm{kDa}$ in extract of all tissues and a further smaller protein product of $49-\mathrm{kDa}$ in testicular extract. Identification of only one transcript of Fafl suggests that the 49-kDa protein would be proteolytically cleaved product of 74-kDa Fafl. Expression pattern of Fafl during testis development reveals that the expression level of the Fafl gene is highly increased at day 25. At the protein level, an equal expression of the $74-\mathrm{kDa}$ isoform was detected throughout testicular development. In contrast, the 49-kDa protein could not be detected in mouse testes till postnatal day 21 . The expression of the $49-\mathrm{kDa}$ isoform could be first detected at day 25. Thereafter, an increasing level of 49-kDa protein was observed. The correlated increase of Fafl transcript and appearance of the 49$\mathrm{kDa}$ protein suggests that the $49-\mathrm{kDa}$ isform is a result of posttranslational modification of 74-kDa Faf1 precursor in haploid spermatid. Immunohistochemistry revealed that the most intense Faf1 immunoreaction was in haploid spermatids. High level of Faf1 was found in cytoplasm of elongated spermatids, while Fafl was diminished in mature spermatids.

Analysis of the mouse gene trap line $98-2 \mathrm{C}$ revealed that the $F a f 1^{G T / G T}$ are died during embryonic development. Northern blot analysis with RNA extracting from different tissues of $\mathrm{Fafl}^{G T /+}$ animals revealed that the gene trap allele transcribes a fusion mRNA of 3.1-kb. Genotyping of embryos from heterozygous intercrosses revealed that the early embryonic development failure of $\mathrm{Fafl}^{G T / G T}$ can be detected past 2-cell stage. These results suggest the essential role of the Fafl for cell viability and/or cell division. The ability of the $F a f 1^{G T / G T}$ to undergo cell division till 2-cell stage can be interpratated by presence of maternal Fafl protein, which would replace the absence of zygotic Fafl protein. Immunoflurescence staining shown that the Fafl protein is presence in oocytes in the ovary, 
in unfertilized oocytes and all preimplantation stages of embryonic development. Embryonic expression of Fafl becomes appreciable at the 4-cell stage as assessed by RTPCR. Thus, the death of Fafl ${ }^{G T / G T}$ may coincide with depletion of maternal Fafl in these embryos. Morphological analysis of embryos at early morula stage, which are isolated from heterozygous intercrosses, suggests that loss of Fafl leads to massive cell death. However, TUNEL assay did not reveal TUNEL-positive cells in necrotic embryo. Therefore, it could not be excluded that Fafl deficiency could led to cell death by a nonapoptotic pathway such as necrosis.

During breeding of heterozygous Fafl mutants, we found some infertile $\mathrm{Fafl}^{G T /+}$ males. Histological analysis revealed that the diameter of the seminiferous tubules was significantly shorter in testis of the infertile males, and the lumens of the tubules were filled with a mass of Sertoli cells and germ cells were completely absent. TUNEL assay did not shown an increase of apoptotic-positive cells in testis of infertile $F a f 1^{G T /+}$ males. This result suggests that the germ cell death like as the death observing in $\mathrm{Fafl}^{G T /+}$ embryos is due to non-apoptotic pathway. In contrast, the expression level of the wild-type allele was higher than that of trapped allele in testis of fertile $\mathrm{Fafl}^{G T /+}$ animals. These results suggest that the haploinsuficiency of Fafl in some $F a f 1^{G T /+}$ causes the germ cell loss.

Fas associated factor 1 (Fafl) was first identified by yeast two hybrid assay using the cytoplasmic domain of FAS as bait. Unlike the Fas associated factor 1 Fafl does not a death domain but processes two ubiquitin homologous domains, the UBA (ubiquitin associated) and UBX (ubiquitin like).

To determine the interacting proteins that bind to the UBX domain, GST-Pulldown assay was done using the GST-UBX fusion protein and protein extracts from testis and brain. The GST-UBX protein interacts with a $96-\mathrm{kDa}$ protein in both assays with testis and brain extracts. The $96-\mathrm{kDa}$ protein was identified as Valosin containing protein (VCP) by peptide mass fingerprinting and confirmed by sequencing. The presence of UBA and UBX domains in primary structure of Faf1 suggest that Faf1 regulates protein degradation in the ubiquitin-proteasome pathway.

The early embryo death of the Faf1 ${ }^{G T / G T}$ prevent us to determine the role of Faf1 in the ubiquitin-proteasome pathway. Therefore, production of conditional knockout mice may be the most promising method for the direct assessment of the function of Fafl during embryogenesis and spermatogenesis 


\section{REFERENCES}

Abbas A. K. (1996) Die and let live: eliminating dangerous lymphocytes. Cell 84: 655-657

Ausubel F. M., Brent R., Kingston R. E., Moore D. D., Seidman J. G., Smith J. A. and Struhl K. (1994) In Current Protocols in Molecular Biology (Greene Publishing Associates and John Wiley \& Sons, Inc., NY) Vol. 1, Ch. 9

Baarends W. M., Roest H. P. and Grootegoed J. A. (1999) The ubiquitin system in gametogenesis. Mol. Cell Endocrinol. 151: 5-16

Bellgrau D., Gold D., Selawry H., Moore J., Franzusoff A. and Duke R. C. (1995) A role for CD95 ligand in preventing graft rejection. Nature 377: 630-632

Birnboim, H. C. and Doly, J. (1979) A rapid alkaline extraction procedure for screening recombinant plasmid DNA. Nucleic Acids Res. 7: 1513-1519

Bradford M. M. (1976) A rapid and sensitive method for the quantitation of microgram quantities of protein utilizing the principle of protein-dye binding. Anal. Biochem. 72: $248-254$

Brenner D. G., Lin-Chao S. and Cohen S. N. (1989) Analysis of mammalian cell genetic regulation in situ by using retrovirus-derived "portable exons" carrying the Escherichia coli lacZ gene. Proc. Natl. Acad. Sci. U S A 86: 5517-5521

Buchberger A. (2002) From UBA to UBX: new words in the ubiquitin vocabulary. Trends Cell Biol. 12: 216-221

Buchou T., Vernet M., Blond O., Jensen H. H., Pointu H., Olsen B. B., Cochet C., Issinger O. G. and Boldyreff B. (2003) Disruption of the regulatory beta subunit of protein kinase CK2 in mice leads to a cell-autonomous defect and early embryonic lethality. Mol. Cell Biol. 23: 908-15 
Chien A., Edgar D. B. and Trela J. M. (1976) Deoxyribonucleic acid polymerase from the extreme thermophile Thermus aquaticus. J Bact. 127: 1550-1557

Chu K., Niu X. and Williams L. T. (1995) A Fas associated protein factor, FAF1, potentiates Fas-mediated apoptosis. Proc. Natl. Acad. Sci. U S A 92: 11894-11898

Clark, J. M. (1988) Novel non-templated nucleotide addition reactions catalyzed by procaryotic and eucaryotic DNA polymerases. Nucleic Acids Res. 16: 9677-9686

Dagert M. and Ehrlich S. D. (1979) Prolonged incubation in calcium chloride improves the competence of Escherichia coli cells. Gene 6: 23-8

Davies E., Hodge R. and Isaac, P. G. (1994) Hybridization and detection of digoxigenin probes on RNA blots. In Methods in Molecular Biology: Protocols for Nucleic Acid Analysis by Nonradioactive Probes 28: 121-125.

Denhardt, D. T. (1966) A membrane-filter technique for the detection of complementary DNA. Biochem. Biophys. Res. Commun. 23: 641-646

Deveraux Q., Ustrell V., Pickart C. and Rechsteiner M. (1994) A 26S protease subunit that binds ubiquitin conjugates. J. Biol. Chem. 269: 7059-61

Dickens B. M. (2002) Can sex selection be ethically tolerated? J Med. Ethics. 28: 335-6

Doelling J. H., Yan N., Kurepa J., Walker J. and Vierstra R. D. (2001) The ubiquitinspecific protease UBP14 is essential for early embryo development in Arabidopsis thaliana. Plant J. 27: 393-405

Dreveny Pye V. E., Beuron F., Briggs L. C., Isaacson R. L., Matthews S. J., McKeown C., Yuan X., Zhang X. and Freemont P. S. (2004) p97 and close encounters of every kind: a brief review. Biochem. Soc. Trans. 32: 715-720

Escalier D., Silvius D. and Xu X. (2003) Spermatogenesis of mice lacking CK2 $\alpha^{\prime}$ : Failure of germ cell survival and characteristic modifications of the spermatid nucleus. Mol. 
Reprod. Dev. 66: 190-201

Feinberg A. P. and Vogelstein B. A. (1989) Technilque for radiolabeling DNA restriction. Nature 342: 705-708

Feng H. Zhong W., Punkosdy G., Gu S., Zhou L., Seabolt E. K. and Kipreos E. T. (1999) CUL- 2 is required for the G1-to-S phase transition and mitotic chromosome condensation in Caenorhabditis elegans. Nature Cell Biol. 8: 486-492

Finley R. W. and Dvorak J. A. (1987) Trypanosoma cruzi: analysis of the population dynamics of heterogeneous mixtures. J. Protozool. 34: 409-15.

French L. E., Tschopp J. (1996) Constitutive Fas Ligand Expression in Several NonLymphoid Mouse Tissues: Implications for Immune-Protection and Cell Turnover. Behring Institute Mitteilungen. 97: 156-160

Fröhlich T., Risau W. and Flamme I. (1998) Characterization of novel nuclear targeting and apoptosis-inducing domains in FAS associated factor 1. J. Cell Sci. 111: 23532363

Gershoni J. and Palade G. (1982) Electrophoretic transfer of proteins from sodium dodecyl sulfate-polyacrylamide gels to a positively charged membrane filter. Anal. Biochem. 124: 396-405

Glotzer M., Murray A. W. and Kirschner M. W. (1991) Cyclin is degraded by the ubiquitin pathway. Nature 349: 132-8

Golbik R., Lupas A., Koretke K., Baumeister W. and Peters J. (1999) The Janus face of the archaeal Cdc48/p97 homologue VAT: protein folding versus unfolding. Biol. Chem. 380: $1049-1062$

Gossler A., Joyner A. L., Rossant .J and Skarnes W. C. (1989) Mouse embryonic stem 
cells and reporter constructs to detect developmentally regulated genes. Science 244: $463-5$

Hodge R. (1994) Preparation of RNA gel blots. Methods Mol. Biol. 28: 49-54

Holloway S. L., Glotzer, M., King, R. W. and Murray A. W. (1993) Anaphase is initiated by proteolysis rather than by the inactivation of maturation-promoting factor. Cell 73: $1393-1402$

Jensen H. H., Hjerrild M., Guerra B., Larsen M. J., Høijrup P. and Boldyreff B. (2001) Phosphorylation of the Fas associated factor FAF1 by protein kinase CK2 and identification of serines 289 and 291 as the in vivo phosphorylation sites. Int. J. Biochem. Cell Biol. 33: 577-589

Kerr W. G., Nolan G. P., Serafini A. T. and Herzenberg L. A. (1989) Transcriptionally defective retroviruses containing lacZ for the in situ detection of endogenous genes and developmentally regulated chromatin. Cold Spring Harbor Symp Quant Biol. 54: $767-776$

Kikyo N., Ridelut W. M., Tada T., Tada M. and Surani M. A. (1996) Mapping of the Fasassociated factor 1 gene, Fafl, to mouse Chromosome 4C6 by FISH. Mam. gen. and Brief Data Report

Koegl M., Hoppe T., Schlenker S., Ulrich H. D., Mayer T. U and Jentsch S. (1999) A novel ubiquitination factor, E4, is involved in multiubiquitin chain assembly. Cell 96: 635-644

Kurz T., Pintard L., Willis J. H., Hamill D. R., Gönczy P., Peter M. and Bowerman B. (2002) Cytoskeletal regulation by the Nedd8 ubiquitin like protein modification pathway. Science 295: 1294-1298

Kusk M., Ahmed R., Thomsen B., Bendixen C., Issinger, O. G. and Boldyrel B. (1999) Interactions of protein kinase CK2 beta subunit within the holoenzyme and with other proteins. Mol. Cell. Biochem. 191: 51-58 
Laemmli U. K. (1970) SDS-Page. Nature 227: 680-685

Laird P. W., Zijderveld A., Linders K., Rudnicki M. A., Jaenisch R. and Berns A. (1991) Simplified mammalian DNA isolation procedure. Nucleic Acids Res. 19: 429

Lee J., Richburg J. H., Younkin S. C. and Boekelheide K. (1997) The Fas system is a key regulator of germ cell apoptosis in the testis. Endocrinology 138: 2081-2088

Lee J., Richburg J. H., Shipp E. B., Meistrich M. L. and Boekelheide K. (1999) The Fas system, a regulator of testicular germ cell apoptosis, is differentially up-regulated in Sertoli cell versus germ cell injury of the testis. Endocrinology 140: 852-8

Ledan E., Polanski Z., Terret M. E. and Maro B. (2001) Meiotic maturation of the mouse oocyte requires an equilibrium between cyclin B synthesis and degradation. Dev. Biol. 232: 400-413

Leon A. and McKearin D. (1999) Identification of TER94, an AAA ATPase protein, as a bam-dependent component of the Drosophila fusome. Mol. Biol. Cell 10: $3825-$ 3834

Li B., Ruiz J. C. and Chun K. T. (2002) CUL-4A Is Critical for Early Embryonic Development. Mol. Cell Biol. 22: 4997-5005

Lorca, T., Cruzalegul, F. H., Fesquet, D., Cavadore, J. C., Méry, J., Means, A., and Dorée, M. (1993) Calmodulin-dependent protein kinase II mediates inactivation of MPF and CSF upon fertilization of xenopus eggs. Nature 366: 270-273

Meyer H. H., Wang Y. and Warren G. (2002) Direct binding of ubiquitin conjugates by the mammalian p97 adaptor complexes, p47 and Ufd1-Np14. EMBO 21: 5645-5652

Moir D., Stewart S. E., Osmond B. C. and Botstein D. (1982) Cold-sensitive cell-divisioncycle mutants of yeast: isolation, properties and pseudoreversion studies. Genetics 100: $547-563$ 
Nagata S. (1997) Apotosis by death factor. Cell 88: 355-365

Nobuhiro S., Burns K. H., Yan W., and Matzuk M. M. (2003) RFPL4 interacts with oocyte proteins of the ubiquitn-proteasome degradation pathway. Proc. Natl. Acad. Sci. USA 100: 550-555

Pintard L., Kurz T., Glaser S., Willis J. H., Peter M. and Bowerman B. (2003) Neddylation and deneddylation of CUL-3is required to target MEI-1/Katanin for degradation at the meiosis-to-mitosis transition in Celegans. Curr.Biol. 13: 911-921

Piko L. and Clegg K. B. (1982) Quantitative changes in total RNA, total ply(A), and ribosomes in early mouse embryos. Dev. Biol. 89: $362-378$

Plachot M., de Grouchy J., Junca A. M., Mandelbaum J., Turleau C., Couillin P., Cohen J. and Salat-Baroux J. (1987) From oocyte to embryo: a model, deduced from in vitro fertilization, for natural selection against chromosome abnormalities. Annales de Genetique 30: 22-32

Roest H. P., van Klaveren J., de Wit J., van Gurp C. G., Koken M. H., Vermey M., van Roijen J. H., Hoogerbrugge J. W., Vreeburg J. T. and Baarends W. M., (1996) Inactivation of the HR6B ubiquitin-conjugating DNA repair enzyme in mice causes male sterility associated with chromatin modification. Cell. 86: 799-810

Romrell L. J., Bellvé A. R. and Fawcett D. W. (1976) Separation of mouse spermatogenic cells by sedimentation velocity. Dev. Biol. 49: 119-131

Russell L. D., Ettlin R. A., Sinha Hikim A. P., and Clegg E. D. (1990) Histological and histopathological evaluation of the testis. Cache River Press, Clearwater, FL

Ryu S. W., Chae S. K., Lee K. J. and Kim E. (1999) Identification and characterization of human Fas associated factor 1, hFAF1. Biochem. Biophys. Res. Commun. 262: 388394

Ryu S. W., Kim H. S., Yoon S. K., Murty V. and Kim E. (2000) Human Fas-Associated 
Factor 1, hFAF1, gene maps to chromosome band 1p32. Mol. Cell 5: 598-600

Ryu S. W. and Kim E. (2001) Apoptosis induced by Human Fas-Associated Factor 1, hFAF1, requires its ubiquitn homologous domain, but not the Fas-binding domain. Biochem. and Biophys. research commun. 286: 1027-1032

Ryu S. W., Lee K. J., Park M. Y., Jun I. J., Jung Y. K. and Kim E. (2003) Fas-Associated Factor 1, FAF1, is a member of Fas death-inducing signaling complex. $J$ Biol. Chem. 278: 24003-240010

Sambrook, J., Fritsch, E. F. and Maniatis, T. (1989). Molecular Cloning - A Laboratory Manual, $2^{\text {nd }}$ Edition

Sanberg P. R., Borlongan C. V., Saporta S. and Cameron D. F. (1996) Testis-derived Sertoli cells survive and provide localized immunoprotection for xenografts in rat brain. Nature Biotech. 14: 1692-5

Sanger F. S., Nicklen A. R. and Coulson A. R. (1977) DNA sequencing with chainterminating inhibitors. Proc. Natl. Acad. Sci. USA 74:5463-7

Saraste A., Pulkki L. M., Heikkila P., Laine P., Nieminen M. S. and Pulkki K. (2000) Soluble tumor necrosis factor receptor levels identify a subgroup of heart failure patients with increased cardiomyocyte apoptosis. Clin. Chim. Acta. 320: 65-67

Sawada H. (2002) Ascidian sperm lysin system. Zool. Sci. 19: 139-151

Schubert C., Richly H., Rumpf S. and Buchberger A. (2004) Shp1 and Ubx2 are adaptors of Cdc48 involved in ubiquitin-dependent protein degradation. EMBO

Schultz R. M. (1993) Regulation of zygotic gene activation in the mouse. BioEssays 15: $531-538$

Shinohara, A., Ogawa, H., Matsuda, Y., Ushio, N., Ikeo, K., and Ogawa T. (1993) Cloning of human, mouse and fission yeast recombination genes homologous to RAD51 and 
recA. Nature Genet. 4: 239-243

Skarnes W. C., Auerbach B. A. and Joyner A. L. (1992) A gene trap approach in mouse embryonic stem cells: the lacZ reported is activated by splicing, reflects endogenous gene expression, and is mutagenic in mice. Genes Dev. 6: 903-18

Sonneville R. and Gonezy P. (2004) P zyg-11 and cul-2 regulate the metaphase to anaphase transition of meiosis II and onset of polarity establishment in C.elegans. Development 131: 3527-3543

Song E. J., Yim S., Kim E., Kim N. and Lee K. (2005) Human Fas-Associated Factor 1, Interacting with Ubiquitnated Protein and Valosin-Containing protein, is involved in the ubiquitn-proteasome pathway. Mol. and Cell. Bol.25: 2511-2524

Southern E. (1975) Detection of specific sequences among DNA fragments separated by gel-electrophoresis. J. Mol. Biol. 98: 503

Stanford W. L., Cohn J. B. and Cordes S.P. (2001) Gene-trap mutagenesis: past, present and beyond. Nat. rev. genet. 10: 756-68

Stanton J. L. and Green D. P. L (2001) Meta-analysis of expression in mouse preimplantation embryo development. Mol. Hum. Reprod. 7: 545-552

Suda T. and Nagata S. (1994) Purification and characterization of the Fas-ligand that induce apoptosis. J. Exp. Chem. 34: 21381-21387

Sun C., Skaletsky H., Birren B., Devon K., Tang Z., Silber S. and Oates R. (1999) An azoospermic man with a de novo point mutation in the Y-chromosomal gene USP9Y. Nature Genet. 23: 429-432

Sutovsky P., Moreno R. D., Ramalho-Santos J., Dominko T., Simerly C. and Schatten G. (1999) Development: Ubiquitin tag for sperm mitochondria. Nature 402: 371 - 372

Sutovsky P., Moreno R., Ramalho-Santos J., Dominko T., Simerly C. and Schatten G. 
(2000) Ubiquitinated sperm mitochondria, selective proteolysis and the regulation of mitochondrial inheritance in mammalian embryos. Biol. Reprod. 63:582-590

Sutovsky P., Moreno R., Ramalho-Santos J., Dominko T., Thompson W. E. and Schatten G. (2001) A putative, ubiquitin-dependent mechanism for the recognition and elimination of defective spermatozoa in the mammalian epididymis. J. Cell Sci. 114:1665-1675

Tokumoto T., Yamashita M., Tokumoto M., Katsu Y., Horiguchi R., Kajiura H. and Nagahama Y. (1997) Inhibition of cyclin B degradation by the 26S proteasome upon egg activation. J. Cell. Biol. 138: 1313-1322

Tsuzuki T., Fujii Y., Sakumi K., Tominaga Y., Nakao K., Sekiguchi M., Matsushiro A., Yoshimura Y. and Morita T. (1996) Targeted disruption of the Rad51 gene lead to lethality in embryonic mice. Proc. Natl. Acad. Sci. USA 93:6236-6240

Tzafrir I., McElver J. A., Liu C. M., Yang L. J., Wu J. Q., Martinez A., Patton D. A. and Meinke D.W. (2002) Diversity of TITAN functions in Arabidopsis seed developmet. Plant Physiol. 128: 38-51

Van de Putte T., Zwijsen A., Lonnoy O., Rybin V., Cozijnsen M., Francis A., Baekelandt V., Kozak C. A., Zerial M. and Huylebroeck D. (2001) Mice with a homozygous gene trap vector insertion in mgcRacGAP die during pre-implantation development. Mech. Dev. 102: 33-44

Walzak H. and Krammer P. H. (2000) The CD95 (APO-1/Fas) and the TRAIL (APO-2L) apoptosis systems. Exp. Cell Res. 256: 58-66

Wilkinson C. R., Seeger M., Hartmann-Peterson R., Stone M., Wallace M., Semple C. and Gordon C. (2001) Proteins containing the UBA domain are able to multi-ubiquitin chains. Nat. Cell Biol. 3: 939-943

Zambrowicz B. P. Friedrich G. A., Buxton E. C., Lilleberg S. L., Person C. and Sands A. T. (1998) Disruption and sequence identification of 2,000 genes in mouse embryonic 
stem cells. Nature 392: 608-611 


\section{ACKNOWLEDGEMENTS}

I wish to express my gratitude in the first place to Prof. Dr. W. Engel for offering me great opportunities in relation to my Ph.D study in the Institute for Humangenetics under his supervision and I am very grateful to him personally for all he has done on my behalf.

Thank you most sincerely and cordially in the second place to PD. Dr. Adham at whose helpful support the work was carried out, and who throughout has gently supervised its progress.

I should greatly appreciate to PD. Dr. S. Hoyer-Fender for having accepted to be my coreferee in this study. I also thanks to Prof. Dr. M. Mühlenberg and Prof.Dr.Ralf Fichner for having accepted to be my examiners.

Very many thanks to my lab colleagues and all of the co-workers in my Institute for their numerous advices, discussions and good working environment.

Finally I deeply thank to my father Ts. Janchiv and sun J.Temuujin for their invaluable help. 


\section{CURRICULUM VITAE}

PERSONAL DATA

Full Name: $\quad$ Janchiv Khulan

E-mail: $\quad$ khulan5j@yahoo.com

Date of birth: $\quad$ April 15, 1969

Sex: $\quad$ female

Nationality: $\quad$ Mongolian

Marital status: $\quad$ Married, 1 child

\section{EDUCATIONAL BACKGROUND}

1. National University of Mongolia, Fuculty of Biology, Ulaanbaatar, Mongolia 19911998.

2. Georg-August University of Göttingen, Germany 2002-2006

\section{DEGREES}

B. Sci and M. Sci in Biology in 1991 and 1998 from National University of Mongolia. M.Sci. Thesis title "Problems in detection of Hepatitis B virus and integration of HBV genome into the host cell"

\section{WORK EXPERIENCE}

1. September 2002-2006

Ph.D student of Georg-August University of Göttingen

2. June 1996-July 2002

Researcher and teaching assistant, Publich health Institute Ulaanbaatar, Mongolia

3. June1987-September 1991 
Research assistant, Department of Human Genetics, Institute of Biotechnology, Mongolian Academy of Science, Ulaanbaatar, Mongolia 